\title{
The 26 December (Boxing Day) 1997 sector collapse and debris avalanche at Soufriere Hills Volcano, Montserrat
}

\author{
B. VOIGHT ${ }^{1}$, J-C KOMOROWSKI ${ }^{2}$, G. E. NORTON ${ }^{15}$, A. B. BELOUSOV ${ }^{4}$. M. BELOUSOVA ${ }^{4}$, \\ G. BOUDON ${ }^{5}$, P. W. FRANCIS ${ }^{6}$, W. FRANZ ${ }^{7}$, P. HEINRICH ${ }^{8}$, R. S. J. SPARKS ${ }^{4}$ \& S. R. YOUNG ${ }^{1 "}$ \\ ${ }^{1}$ Geosciences, Penn State University, University Park, PA 16802, USA (e-mail: voight@ems.psu.edu) \\ ${ }^{2}$ Observatoire Volcanologique de la Soufriere (IPGP), Le Houelmont, Gourbeyre 971113, Guadeloupe \\ ${ }^{3}$ British Geological Survey, Keyworth, Nottingham, NG12 5GG, UK \\ ${ }^{4}$ Institute of Volcanic Geology and Geochemistry, Petropavlovsk-Kamchatsky, 683006, Russia \\ ${ }^{5}$ Institut de Physique du Globe de Paris (IPGP), 4 Place Jussieu, B 89, 75252 Cedex 05 Paris, France \\ ${ }^{6}$ Department of Earth Sciences, Open University, Milton Keynes MK7 6 A A, UK (deceased) \\ ${ }^{7}$ Gannett-Fleming Engineers, Harrisburg, PA 17110, USA \\ ${ }^{8}$ Laboratoire de Detection et de Geophysique, Commisariat a l'Energie Atomique, BP 12, 91680 Bruyeres-le-Chatel, France \\ ${ }^{9}$ Department of Earth Sciences, Bristol University, Bristol, BS8 1RJ, UK \\ ${ }^{10}$ Montserrat Volcano Observatory, Montserrat, West Indies
}

\begin{abstract}
The southern sector of Soufriere Hills Volcano failed on 26 December 1997 (Boxing Day), after a year of disturbance culminating in a devastating eruptive episode. Sector collapse produced a $c .50 \times 10^{6} \mathrm{~m}^{3}$ volcanic debris avalanche, and depressurized the interior of the lava dome, which exploded to generate a violent pyroclaslic density current. The south-directed growth of a lava lobe and build-up of lava-block talus, since early November 1997. brought the hydrothermally weakened sector to a condition of marginal stability. Limit-equilibrium stability analyses and finite-difference stress-deformation analyses, constrained by geomechanical testing of edifice and debris avalanche materials, suggest that the sector collapse was triggered by a pulse of co-seismic exogenous lava shear-lobe emplacement. Slip-surface localization was influenced by strain-weakening.

The source region fragmented into avalanche megablocks, and further disruption generated a chaotic avalanche mixture that included variably indurated and coloured hydrothermally altered material, and much talus. The avalanche consisted of several flow pulses that reflected complexities of source disruption and channel topography. In the proximal zone, within $1.5 \mathrm{~km}$ from source, many megablocks preserve pre-collapse stratigraphy. At major bends the avalanche separated into channelled and overspill flows. In the distal region, $>2.5 \mathrm{~km}$ from source, stacked sets of the main lithologies occur with a hummocky surface and abrupt flowage snouts, beyond which sparse hummocks occur in a thinly spread deposit. Textures suggest emplacement by laminar mass transport of partly saturated debris riding on a frictionally sheared base. Three-dimensional numerical simulations of emplacement governed by a Coulomb-type (Pouliquen) basal friction law imply low values of friction $\left(<15^{\circ}\right)$, consistent with geotechnical test data and the localized presence of pore-water pressures. The best-fit model suggests an emplacement time $<3$ minutes and a typical maximum velocity of about $40 \mathrm{~ms}^{-1}$, which are consistent with field estimates.
\end{abstract}

Following over a year of disturbance, the southern flank of Soufriere Hills Volcano failed on 26 December (Boxing Day) 1997, generating the most devastating episode of the entire eruption (Sparks et al. 2002). The complex series of events resembles, on a smaller scale, the debris avalanche and directed blast that occurred at Mount St Helens in 1980 (Lipman \& Mullineaux 1981). At Soufriere Hills, an andesilic lava dome had grown over the unstable, hydrothermally weakened southern sector of the edifice. When this sector collapsed on Boxing Day, the interior of the lava dome was exposed and depressurized, and it exploded to generate a powerful pyroclastic density current that ravaged the southwestern flank and entered the sea.

This paper focuses on the mechanics of the sector collapse and on the emplacement dynamics, characteristics and properties of the deposit of the resulting debris avalanche (Fig. I). It is based primarily on fieldwork conducted at various times in 1998 and 1999, with some access limitations due to safety considerations related to ongoing activity. Some sampling and analyses were conducted as early as 1996.

\section{Pre-collapse conditions: geological setting and precursory activity}

The Boxing Day collapse was the culmination of a series of events that affected the geometry and conditions of the southern flank (Sparks et al. 2002; Young el al. 2002). Only the main points need

In honour of our fallen comrade, Peter Francis. be summarized here. The eruption of Soufriere Hills Volcano involved the growth of an andesitic lava dome within the confines of English's Crater (Fig. 2). a horseshoe-shaped depression produced by a prehistoric flank collapse (Wadge \& Isaacs 1988; Boudon et al. 1996). This depression, about $1 \mathrm{~km}$ wide, with interior walls $100-$ $150 \mathrm{~m}$ high and open to the east, had been partly filled by a young (c. 350 BP) lava dome known as Castle Peak, and a semi-circular moat existed between this dome and the walls of English's Crater (Fig. 2). The new lava extrusion began in mid-November 1995, and through 1996 was confined to English's Crater, although some pyroclastic flows travelled eastwards to the sea (Young et al. 1998).

The Boxing Day sector collapse involved the flank including Galway's Wall and Galway's Soufriere (Fig. 2). Galway's Wall marked the southern edge of English's Crater, and extended about $600 \mathrm{~m}$ from Chances Peak to Galway's Mountain (Fig. 3). The outer, southward-facing side of Galway's Wall was precipitous and composed of pyrodastic breccias and tuffs related to the formation of the Chances Peak and Galway's domes (Young et al. 2002). South of Galway's Wall was the Galway's Soufriere fumarolic field (Figs 4 and 5), an area of active, acid hydrothermal activity at an altitude of 400-500 m within the upper White River valley (Boudon et al. 1998).

Galway's Wall was not much affected by events at the volcano until June 1996, when active dome growth shed talus into the moat between Castle Peak and Galway's Wall. After an eastward-directed dome collapse followed by an explosion on 17 September 1996 (Robertson et al. 1998), renewed growth occurred between October and December 1996. Fractures on the western buttress of Galway's Wall and within the wall itself were observed in late November, and continued to open into December 1996 (Young et al. 2002). During 


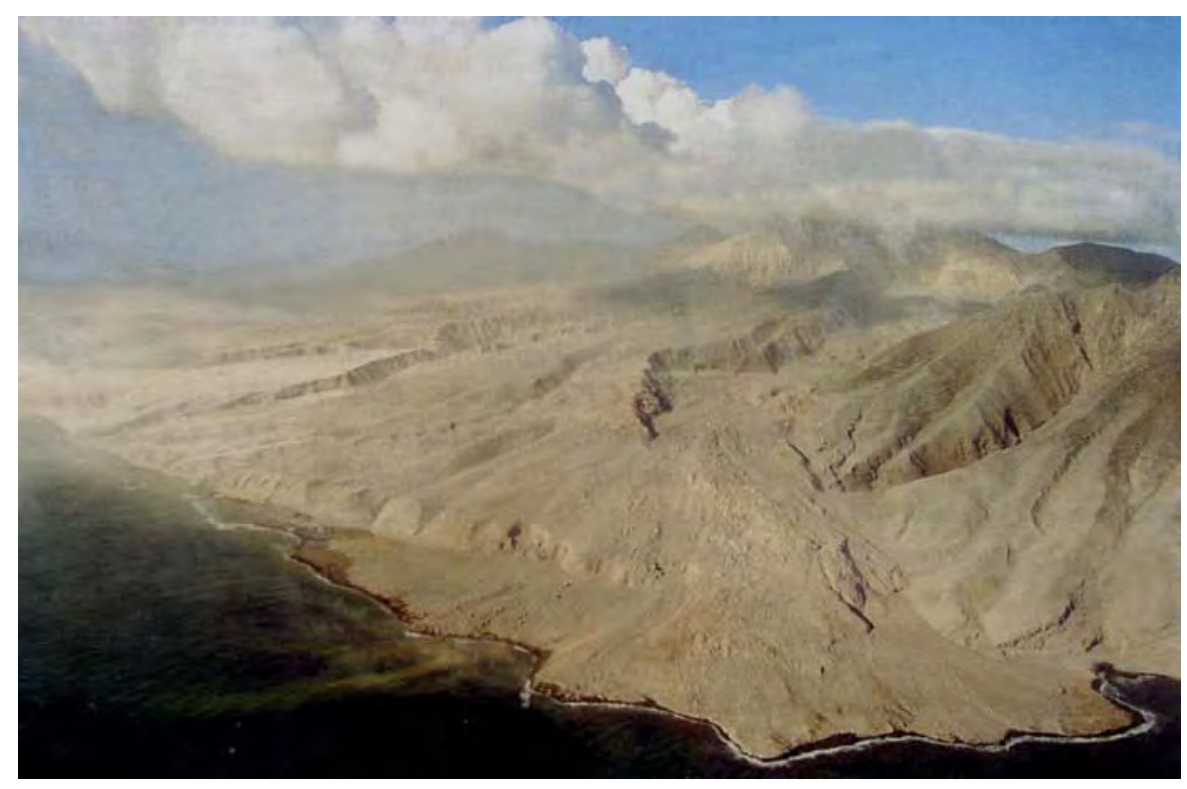

(a)

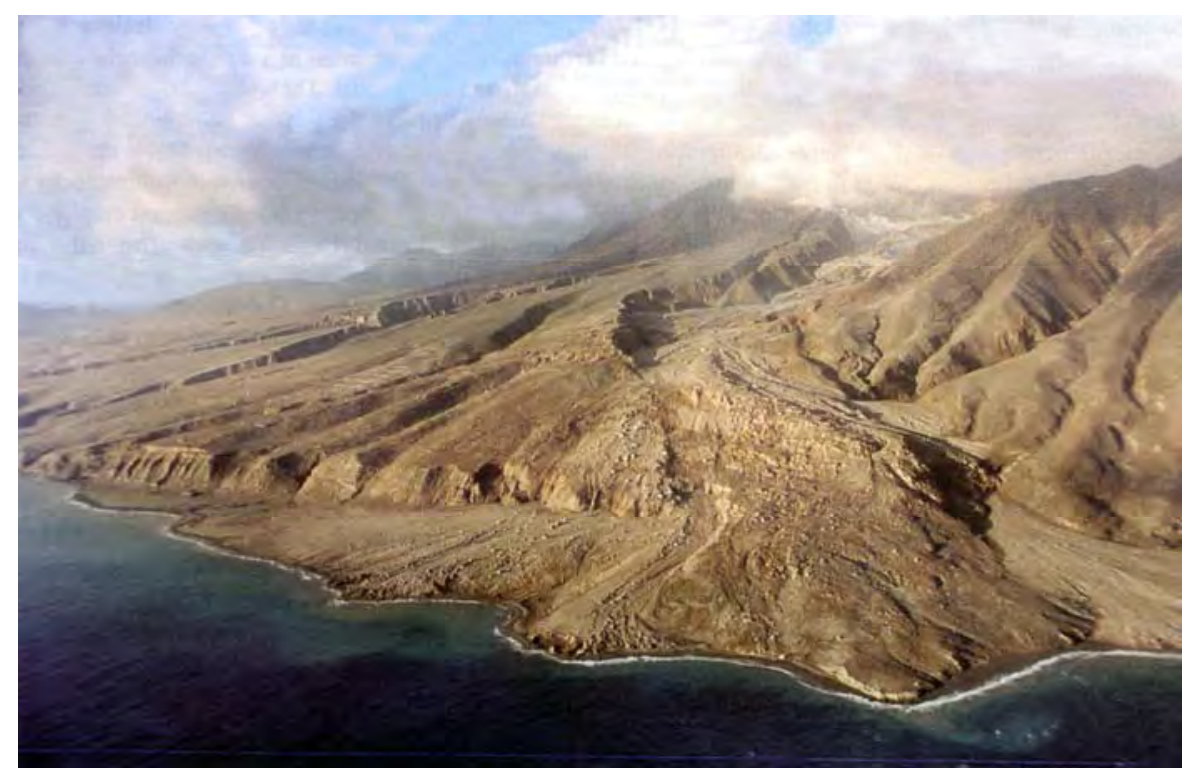

(b)

Fig. 1. View northwards from the mouth of the White River, showing Boxing Day debris avalanche and tephra deposits on the south flank of Soufriere Hills Volcano as seen (a) about four days after deposition (photo MVO). and (b) in summer 1998 (photo K. West). Fergus Mountain on middle right, towns of Morris' and St Patricks to left of White River channel. Much of the ground surface (a) was veneered by pyroclastic density current deposit and associated fallout deposits, but in (b) most of these deposits had been eroded, and the debris avalanche deposits were etched in greater detail. Boxing Day deposits had extended the fan built by pyroclastic flows associated with Vulcanian explosions in October 1997 and the dome collapses of early November 1997.

this period, strong hybrid swarm seismicity occurred and triggered rockfalls from jointed tuffs exposed on Galway's Wall (Fig. 3). These earthquake swarms were interpreted as reflecting shallow intrusion. Montserrat Volcano Observatory (MVO) scientists expressed concern to officials and the public about the possibilities of collapse of Galway's Wall and an ensuing lateral volcanic blast, and as a consequence the area at risk was evacuated (Young et al. 2002). At about the same lime, tsunami risk evaluations were carried out, qualitatively by B.V. at Montserrat, and quantitatively for the coast of Montserrat and neighbouring northern Guadaloupe by French scientists in collaboration with the MVO (Heinrich el al. 1998). Later, at the time of the catastrophic events on 26 December 1997, there was no loss of life because the earlier evacuation had been maintained despite some public pressure to end it.

In late March and April 1997, dome growth again shifted to the south, lava overtopped the low point on Galway's Wall, and blockand-ash flows eroded parts of it (Sparks et al. 2002. fig. 2a), Rock in the vicinity of Galway's Soufriere was partially buried by talus and block-and-ash flow deposits (Figs 6 to 8). From May through to October 1997 dome activity shifted away from Galway's Wall, but renewed growth here in November generated two major partial dome collapses on the southern flank, in total involving about $8 \times 10^{6} \mathrm{~m}^{3}$ 

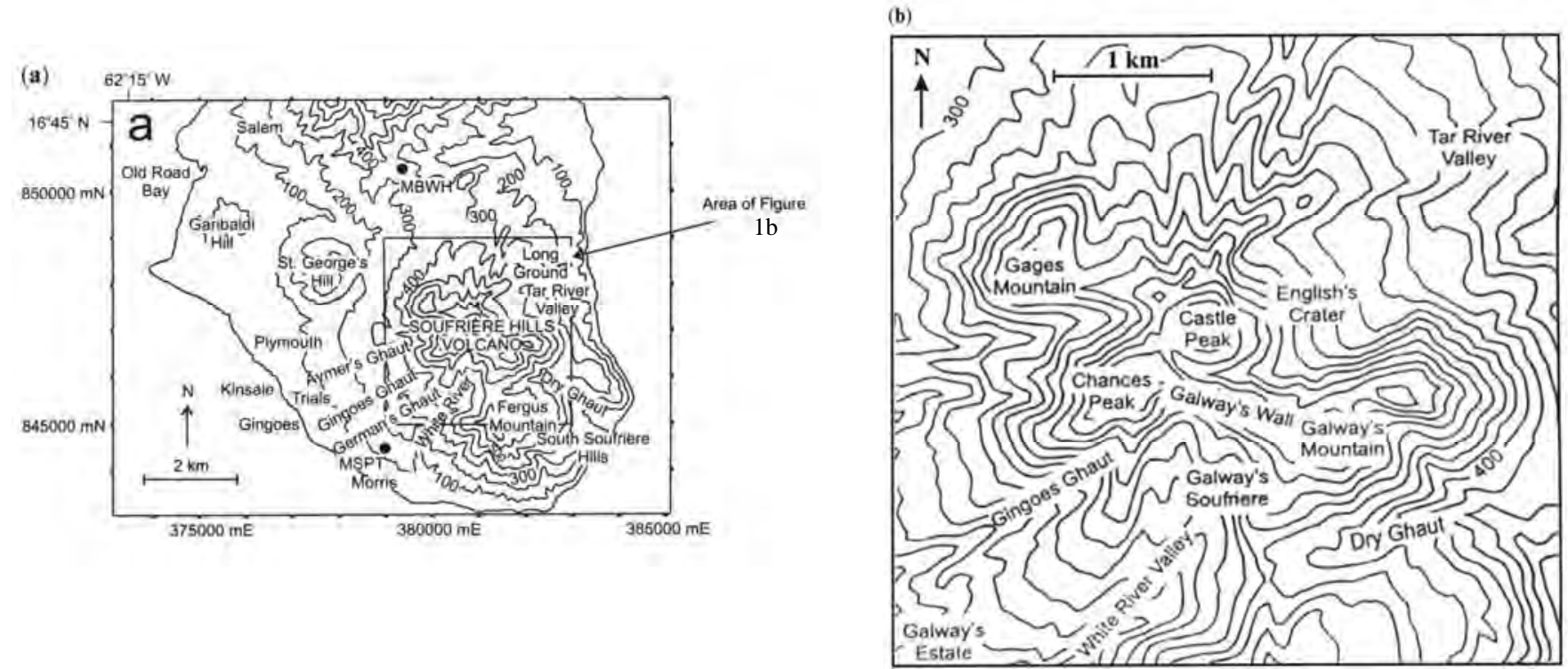

Fig. 2. (a) Topographic map of southern Monlserrat, showing place names and features described in text. Seismic stations at Windy Hill (MBWH) and St Patrick's (MSPT) are shown by dots. (b) Detail of English's Crater and upper flanks of the Soufriere Hills dome complex (after Sparks el al. 2002).

of material. Further dome growth in November and December 1997 was rapid, a lobe of lava was squeezed over remnants of Galway's Wall, and an apron of dome talus extended to bury terrain near Galway's Soufriere (Fig. 9). By 8 December 1997 the dome had reached a volume of $102 \times 10^{6} \mathrm{~m}^{3}$, and by 25 December this had increased to $113 \times 10^{6} \mathrm{~m}^{3}$ (Figs 6-11; Sparks el al. 2002).

The short-term build-up to the Boxing Day collapse was rapid (Sparks el al. 2002). Al 14:30 (local time, LT) on 24 December, a distinct hybrid earthquake swarm began (see Miller et al. (1998) for discussion of types of seismicity) and it increased until 20:00 on 25 December when it merged into continuous tremor. The earthquakes increased in amplitude, but were smaller than those recorded in early November. The amplitude of the tremor peaked at 23:00 on 25 December, then declined until midnight when individual events could again be detected. Tremor resumed at 01:30 on 26 December and built in amplitude to the onset of the collapse at 03:01.

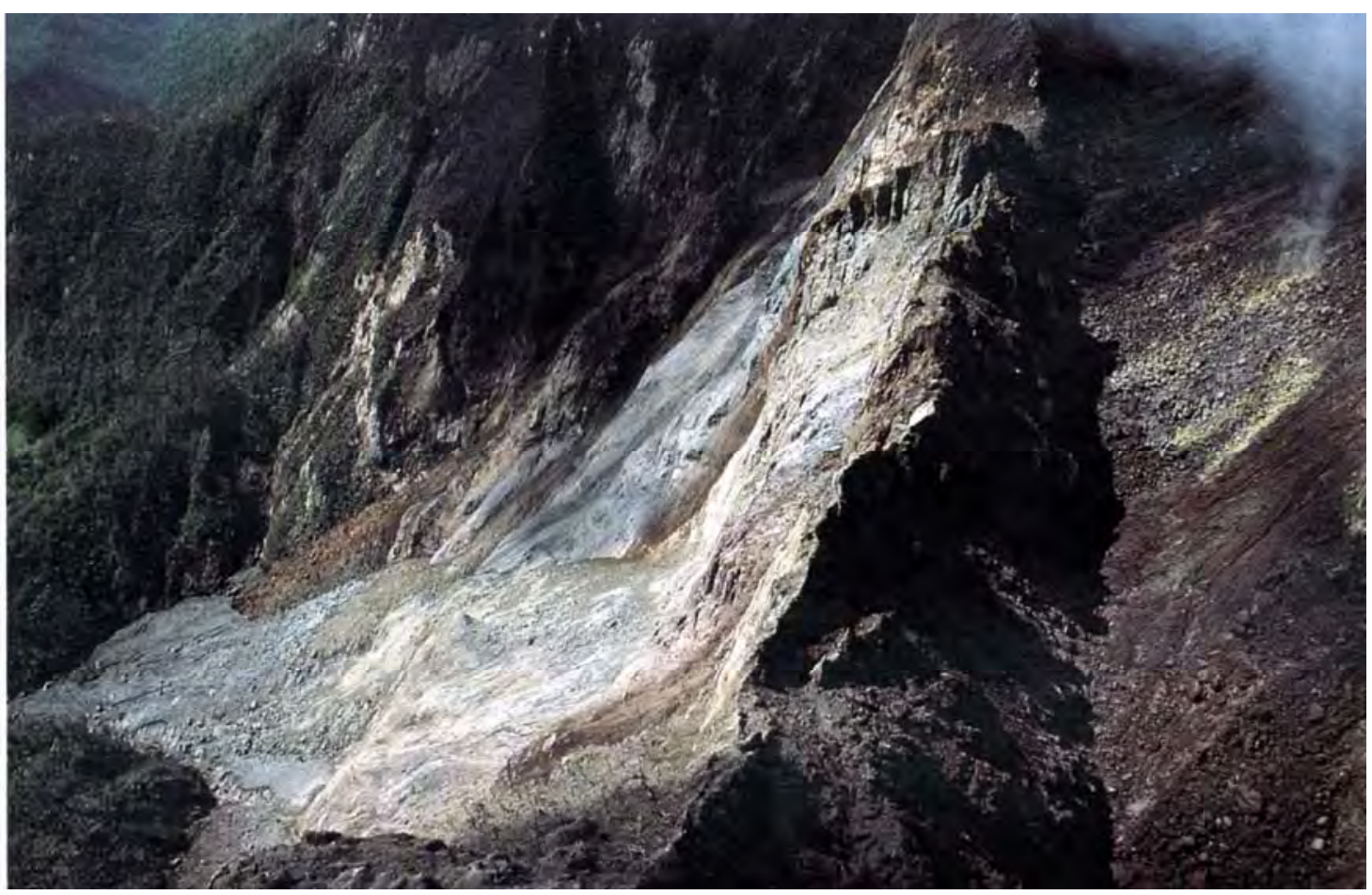

Fig. 3. View west along the axis of Galway's Wall in early December 1996. Chances Peak forms west buttress, White River valley is to the left, and the growing lava dome is to the right. At this time, the jointed tufts of Galway's Wall were collapsing in a series of earthquake-triggered slab rookfalls, and MVO scientists became concerned about the possibility of a larger wall collapse that might trigger a lateral dome explosion. By March the dome lavas began to overtop and erode the wall. Active dome growth in this sector recommenced in late 1997 and culminated in the 26 December sector collapse (photo B.V.). 

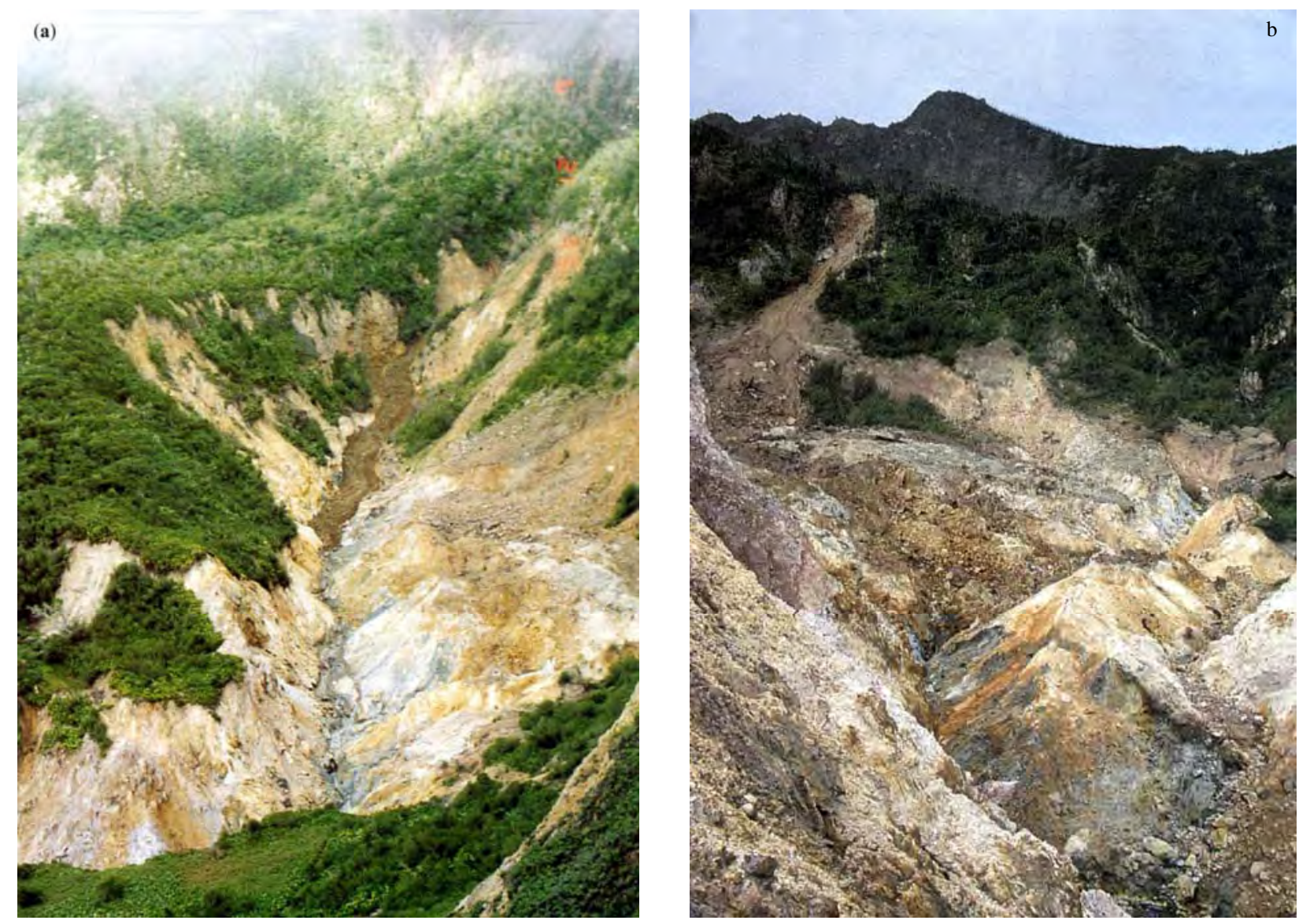

Fig. 4. Galway's Soufriere. (a) View NW into the soufriere on 7 December 1996. The Soufriere extends into the hill between the White River valley and Galway's Wall (photo MVO). Portions of thiis area moved in slump landslides in December 1996. Brown deposit in river valley is distal flow snout of fresh, earthquake-triggered rockfall from the Galway's Wall, (b) The soufriere, looking northward from valley bottom, 26 March 1996, showing varicoloured, weak, highly altered tuffs in the valley and adjacent hill, with the Galway's Wall in the background (photo B.V.).

\section{Chronology of the collapse}

Seismicity provides the main constraint on the timing of events. The main collapse event has been divided into six pulses. Sparks et al. (2002) suggest that the start time of the main collapse was 03:01.0 LT and the finish of major dome disintegration was 03:16.2. The spectral frequency of seismicity during the collapse was similar to that for the hybrids and tremor prior to the collapse, with the dominant frequency below $2.8 \mathrm{~Hz}$. The form of the collapse signal was similar to that produced by the 6 November 1997 dome collapse and associated block-and-ash flow activity, but the signal amplitude in December was about five times greater.

GOES-8 satellite data give information on the plume associated with the explosion and pyroclastic density current, but no information on the collapse (Mayberry et al. 1998). Only in the morning after the event did it become clear that a substantial sector collapse had occurred, accompanied by major destruction of the lava dome.

\section{Post-collapse morphology and collapse volume estimates}

The collapse and explosion produced two major scars (Figs $9 \mathrm{~b}$ and $12 \mathrm{~b})$. The lower scar, formed by the sector collapse, was about $400 \mathrm{~m}$ wide. Its northern boundary formed an arcuate step roughly $100 \mathrm{~m}$ high, located approximately along the southern, steeply sloping edge of the remnant of Galway's Wall (Figs 9b and 13b),
The floor of the scar, which represented the shear-slip surface of the collapse, extended to the south about 400-500 m in the White River valley where it was buried by fragmenlal deposits. At the southern part of the scar, a patch of discoloured deposits with steaming fumaroles was interpreted as material that buried remnants of Galway's Soufriere (Fig. 13b).

The upper scar was a spoon-shaped amphitheatre within the dome, as much as $400 \mathrm{~m}$ wide and extending about $450 \mathrm{~m}$ north of the step (Figs 9b and 13b). The upper scar is interpreted as originating by a combination of gravitational failure and spontaneous, explosive quarrying processes involving gas-pressurized, highly crystalline but partly molten dome rock. The southern part of the upper scar may have been produced by retrogressive collapse involving dome material and fragments from Galway's Wall.

Sparks et al. (2002) estimate roughly the volume of material involved in the failure, from the dimensions of the scars and by comparison with the pre-collapse topography of the Galway's Soufriere area and the dome: $c$. 20-30 x $10^{6} \mathrm{~m}^{3}$ of hydrothermally altered rocks from the Galway's Soufriere area; c. $5 \times 10^{6} \mathrm{~m}^{3}$ of Galway's wall; c. $25 \times 10^{6} \mathrm{~m}^{3}$ of the lava dome that had grown between 6 November and 26 December: and c. $30 \times 10^{6} \mathrm{~m}^{3}$ of dome talus deposited beyond Galway's Wall, reaching toward the Galway's Soufriere. Thus, overall the failure involved c. $80-90 \times 10^{6} \mathrm{~m}^{3}$ of material, with the sector collapse alone, from these estimates, accounting for roughly $50 \times 10^{6} \mathrm{~m}^{3}$. The uncertainty of these estimates may exceed $15 \%$. Independent estimates, based on valley-fill deposits, are discussed below. 

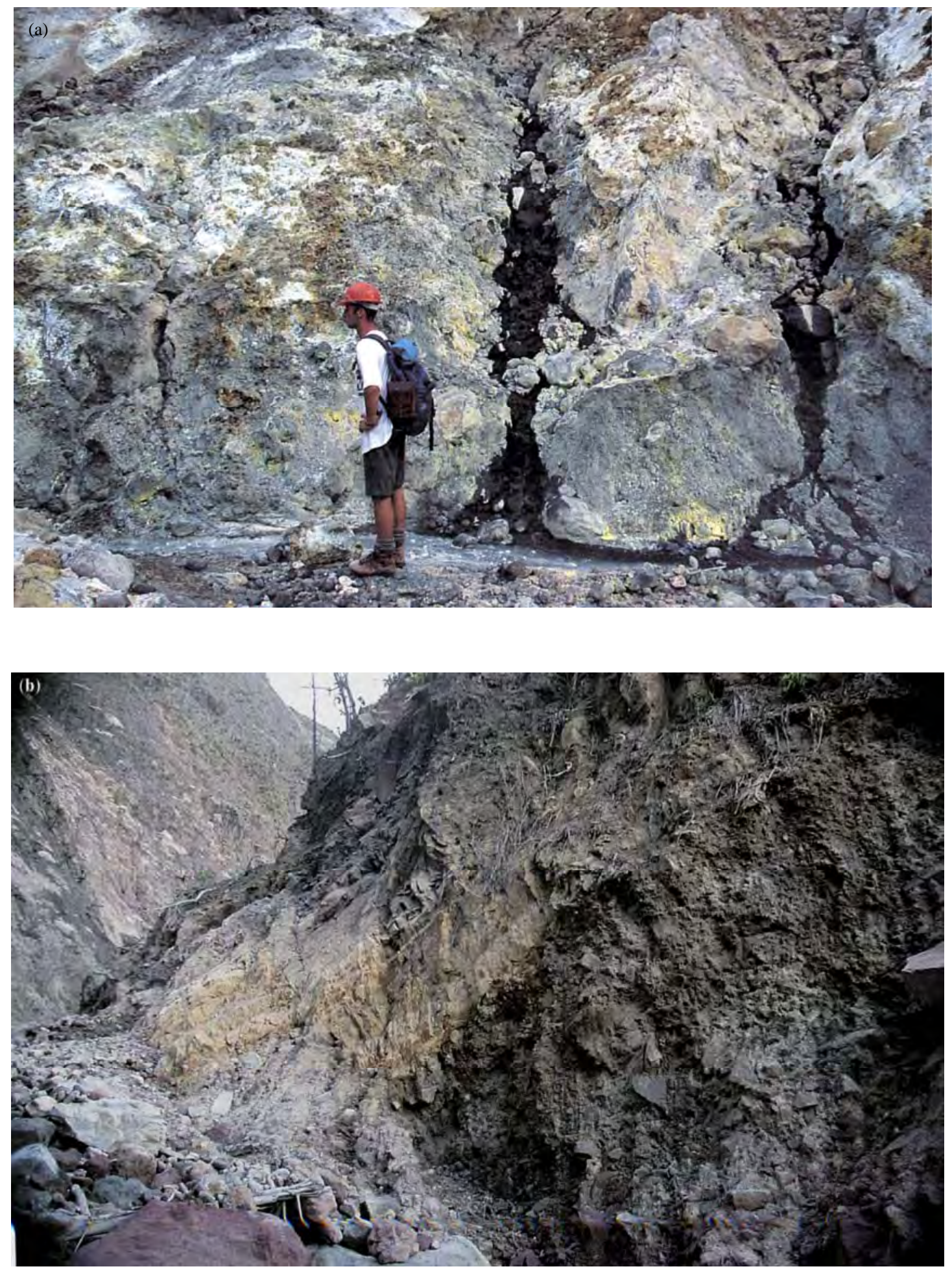

Fig. 5. Geology of the hill beween Galway's Soufriere and Galway's Wall, observed from uppermost White River valley, (a) East side of White River valley between the Soufriere and Galway's Wall on 26 March 1996. Sulphur-encrusted, partly altered pyroclastic breccia of prehistoric block-and-ash flow deposits. S.R.Y. is scale (photo B.V.). (b) Similar location and date, at boundary with Galway's Wall (to left of notch). A few metres from Galway's Wall, the north-dipping, layered pyroclastic breccias and tuffs of hill were offset $1 \mathrm{~m}$ by normal fault that displaced the sequence to the south. We speculate on the possibility of this hill as a prehistoric slump block (photo B.V.).

\section{Volcanic debris avalanche deposit}

\section{Genera! description}

The avalanche deposit consisted of unconsolidated. poorly sorted volcaniclastic debris that buried about $2.7 \mathrm{~km}^{2}$ of the White River valley and valley margins (Figs 13 to 15 ). The deposit spanned about $4 \mathrm{~km}$ in length (uppermost parts are buried by fresh, post-Boxing Day dome talus) and was about 200 to $700 \mathrm{~m}$ wide. In the lower part of the valley, it was typically about $400 \mathrm{~m}$ wide, and about 25-70 m thick. Topographic surveys of the White River valley area were carried out within three weeks of the collapse (Figs 16 and 17), and compared with a survey carried out after the 


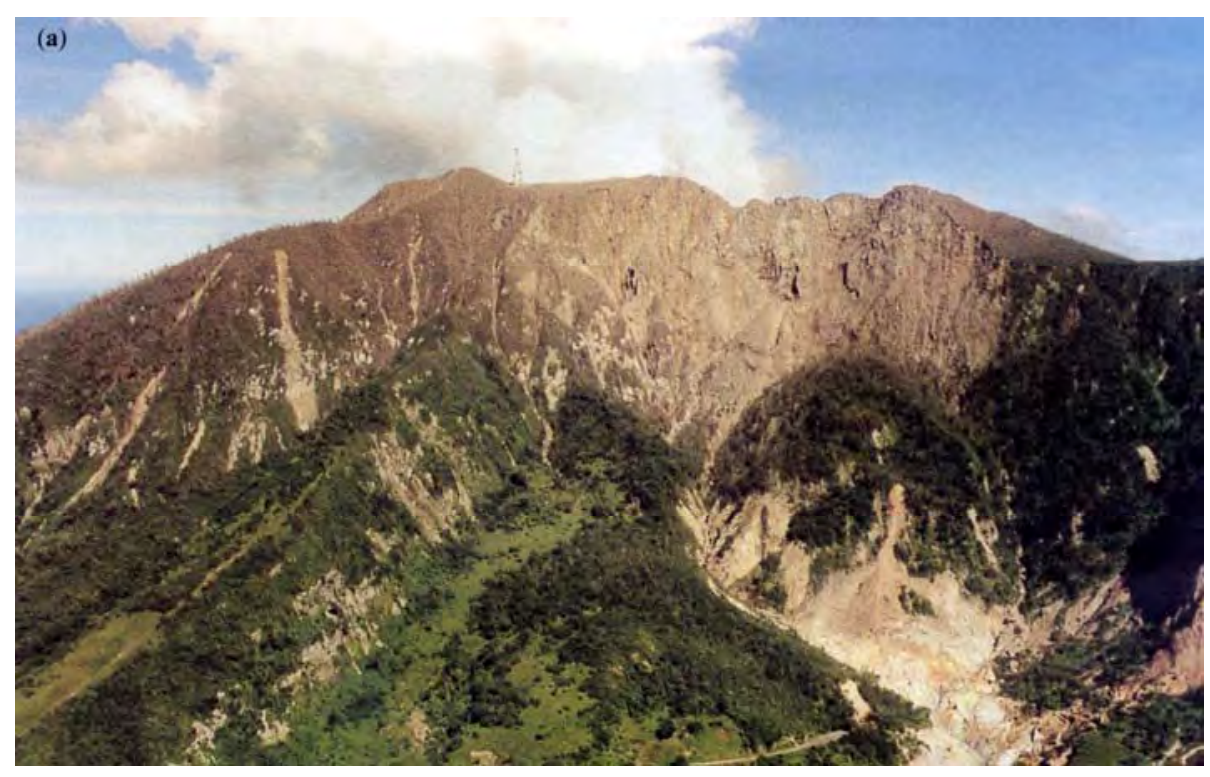

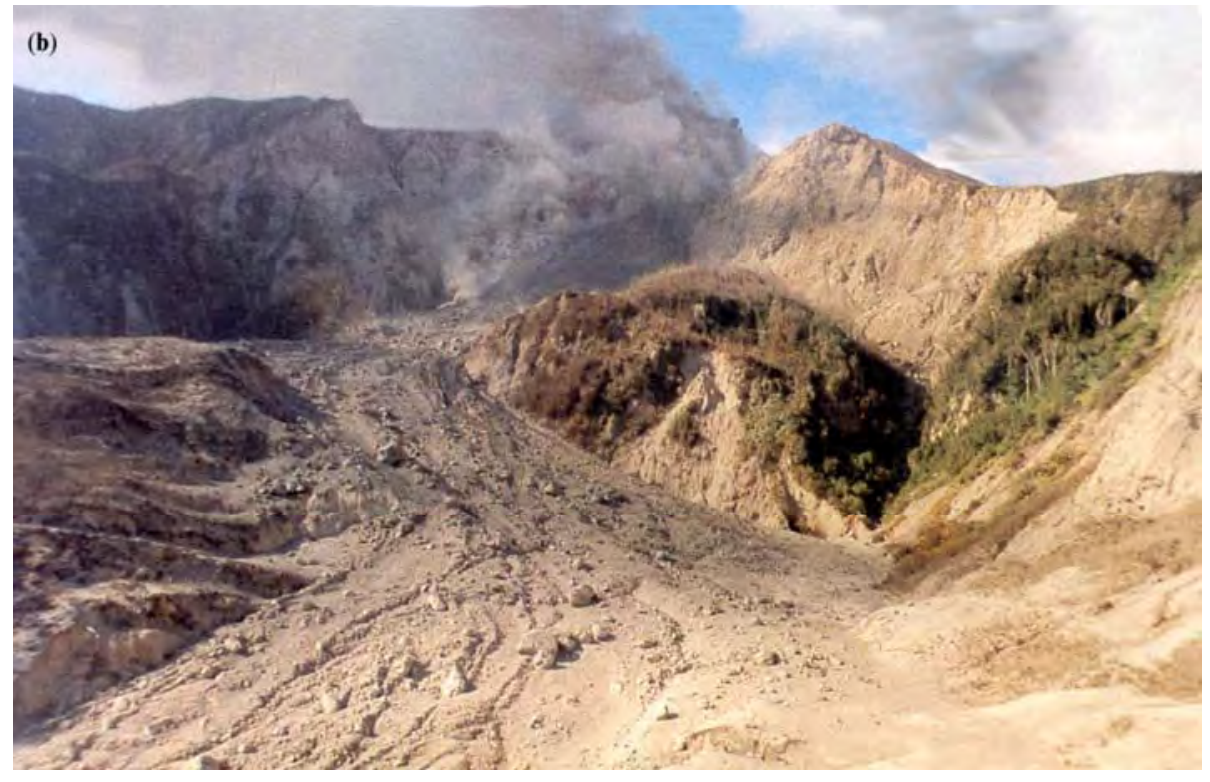

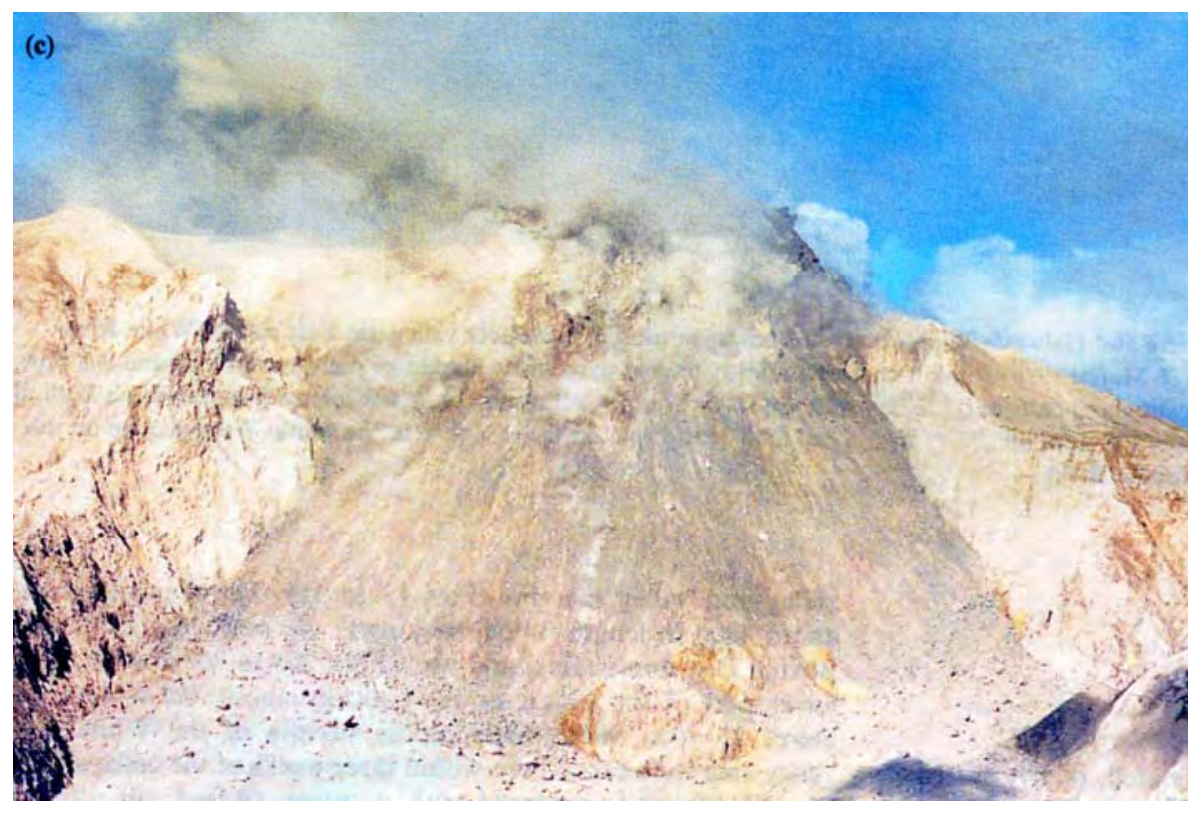

Fig. 6. Upper White River valley, as viewed from south, (a) In December 1996, Galway's Wall extended from Galway's Mountain on the right, to Chances Peak, where the radio tower marked a tiltmeter site. An access road led from the south coast to Galway's Soufriere, shown by pale colours in the river valley, with the alteration affecting also the mound-like hill between the valley and Galway's Wall (photo K. West), (b) By late April 1997, the river valley and much of the Soufriere were being buried by block-and-ash flow deposits produced by collapses from the active lava dome (photo K. West). (c) By 8 December 1997, extensive southerly growth of the lava dome had generated talus that almost completely buried the hill shown in (a) and (b) (photo MVO). Minor changes in talus volume occurred between this date and the sector collapse of 26 December 1997. The pale-coloured landscape reflects the dusting of ash from numerous rockfalls. 

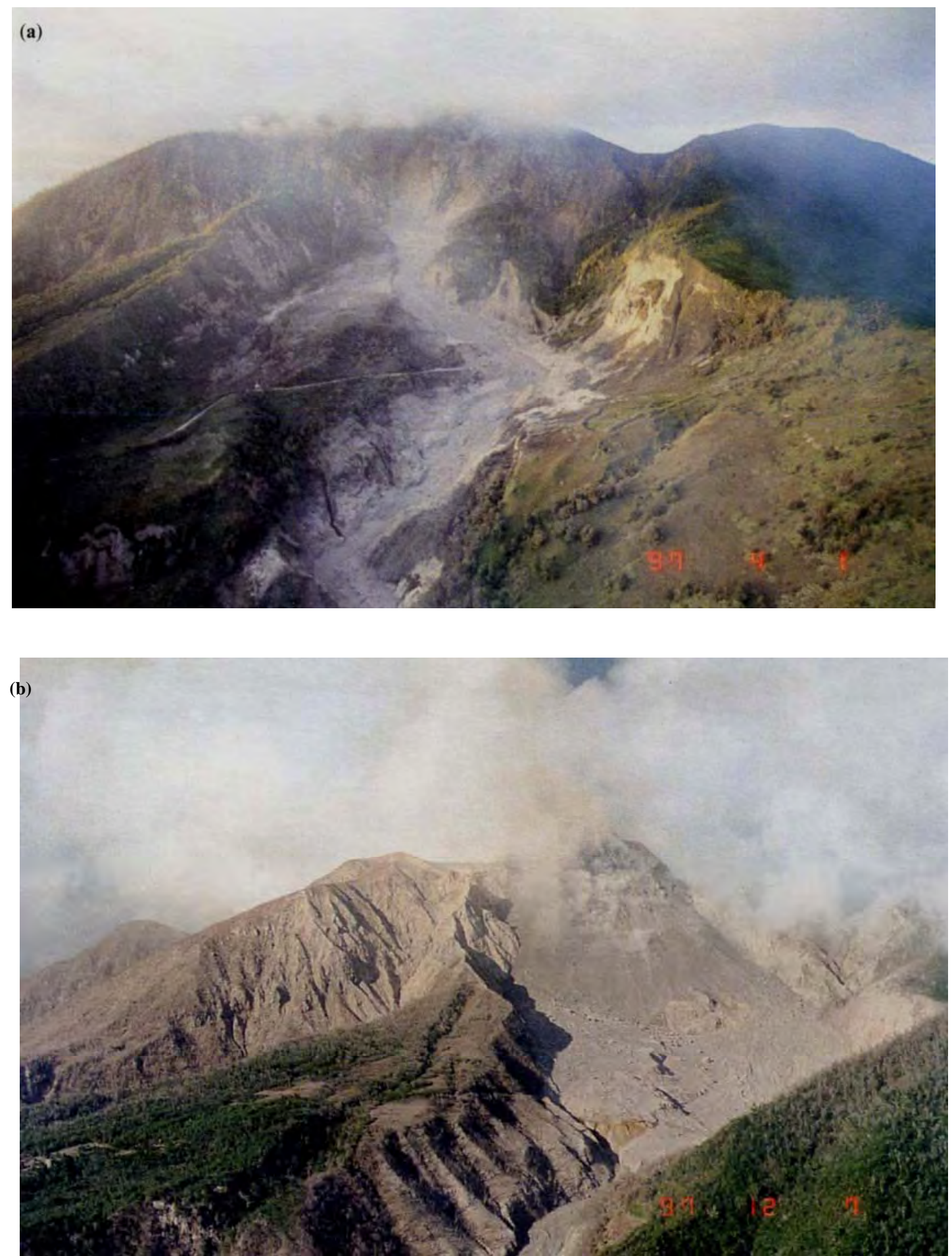

Fig. 7. Upper White River valley, as viewed from southwest. (a) By 1 April 1997, the valley and soufriere were being partly buried by rock falls from Galway's Wall, and by block-and-ash flow deposits from lava dome collapses. Access road at left centre. Notched hill is above soufriere, between valley and Galway's Wall (photo MVO). (b) By 8 December 1997, most features within the valley shown in (a) had been buried by a talus cone, setting the stage for edifice collapse about two weeks later. The talus was being fed by southward-moving lava at the top of the cone (photo MVO).

4-6 November 1997 dome collapse. The volume of material in the (lower) White River valley and delta was determined as $46 \times 10^{6} \mathrm{~m}^{3}$ (Sparks el al. 2002).

Most of the valley till was the debris avalanche deposit, although block-and-ash flow deposits derived from the dome disintegration, and some subsequent explosions, covered much of the avalanche deposit and infilled depressions on its top. The debris avalanche deposit volume was substantially greater than the volume of the remnant collapse scar, but the residual scar, indented into the valley floor, did not reflect the full thickness and volume of material that had been lost. Considering the volume estimates from both the source area and the valley deposits, and allowing for uncertainty, we estimated the debris avalanche volume as about $40-50 \times 10^{6} \mathrm{~m}^{3}$. The uncertainties associated with the volume estimates prevented the volumetric bulking (increase in pore space) associated with avalanche emplacement to be determined, although bulking may have been minor inasmuch as much of the source material had significant initial porosity.

The debris avalanche deposit extended throughout the White River valley, from the region of its partly infilled source scar, to its southern distal margin on the coastal fan of pyroclaslic deposits at the mouth of the valley (Figs 13 to 16). It reached to within about 

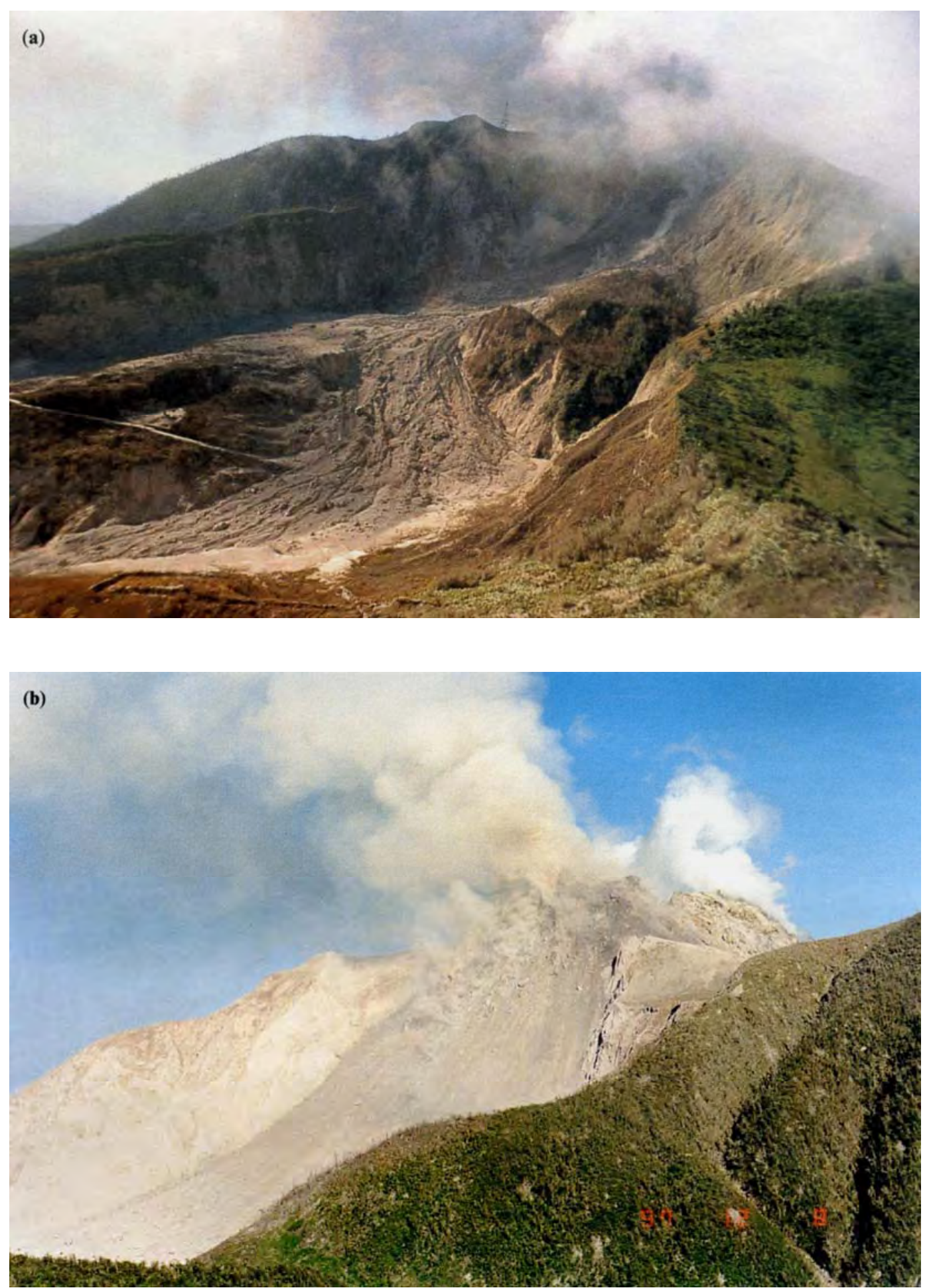

Fig. 8. Upper White River valley, as viewed from east, (a) By 22 April 1997, the river channel and Galway's Soufriere was buried by, mainly, block-and-ash flows from dome collapse. To the right of valley is notched hill, and farther to the right is Galway's Wall. Chances Peak is in the background (photo K. West), (b) By 8 December 1997, a talus cone had buried the topographic features of the uppermost valley. The talus was fed by a lava lobe that moved southward over the eroded Galway's Wall, seen at top right (photo MVO).

$20 \mathrm{~m}$ from the sea (Komorowski et al. 1999). Near the coast it outcropped as a broad veneer with mounds $0.5-1 \mathrm{~m}$ high and patches of multicoloured hydrothermally altered clastic debris. At about 400-800 m northward from the sea, particularly near the eastern margin, several pronounced, but crudely developed, topographic steps were formed in the debris avalanche deposit (Figs 1, 18 and 19). In plan view the steps were curved such that positions near the channel centre were displaced farther down-valley than positions near the margins. Each step represented the front of a flow lobe, and the succession of steps was formed by imbrication of successive tongues of avalanche debris. The effect of this process, which must have been rapid (see below), was to produce a stair-step profile near the eastern margin, with each step about 20-25 m high, succeeded by a rough bench (3-10 m relief), then another step, and another, for a total relief of $60-70 \mathrm{~m}$ above the distal sheet-like portion of the deposit nearer the coast. The pattern in plan view suggested that avalanche flow in the eastern portion of the channel was impeded by a ridge of older rock protruding above the channel floor, which had not been completely buried by previous 1997 deposits. Flow in the other part of the channel was unobstructed, and there the avalanche reached a greater distance, nearly to the sea. 


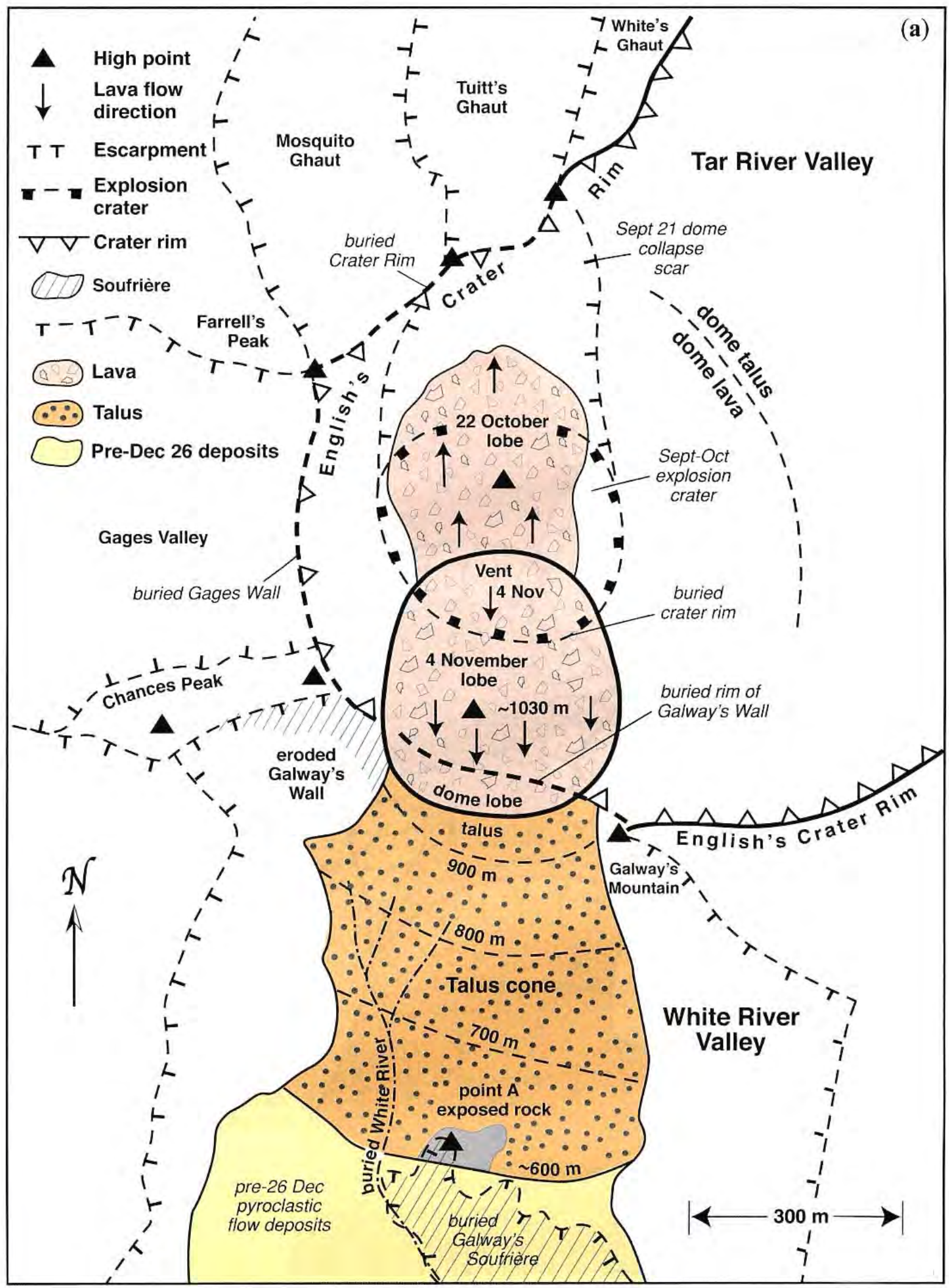

Fig. 9. Maps of Galway's Wall area (a) before and (b) after the 26 December collapse (cf. Fig. 12). 


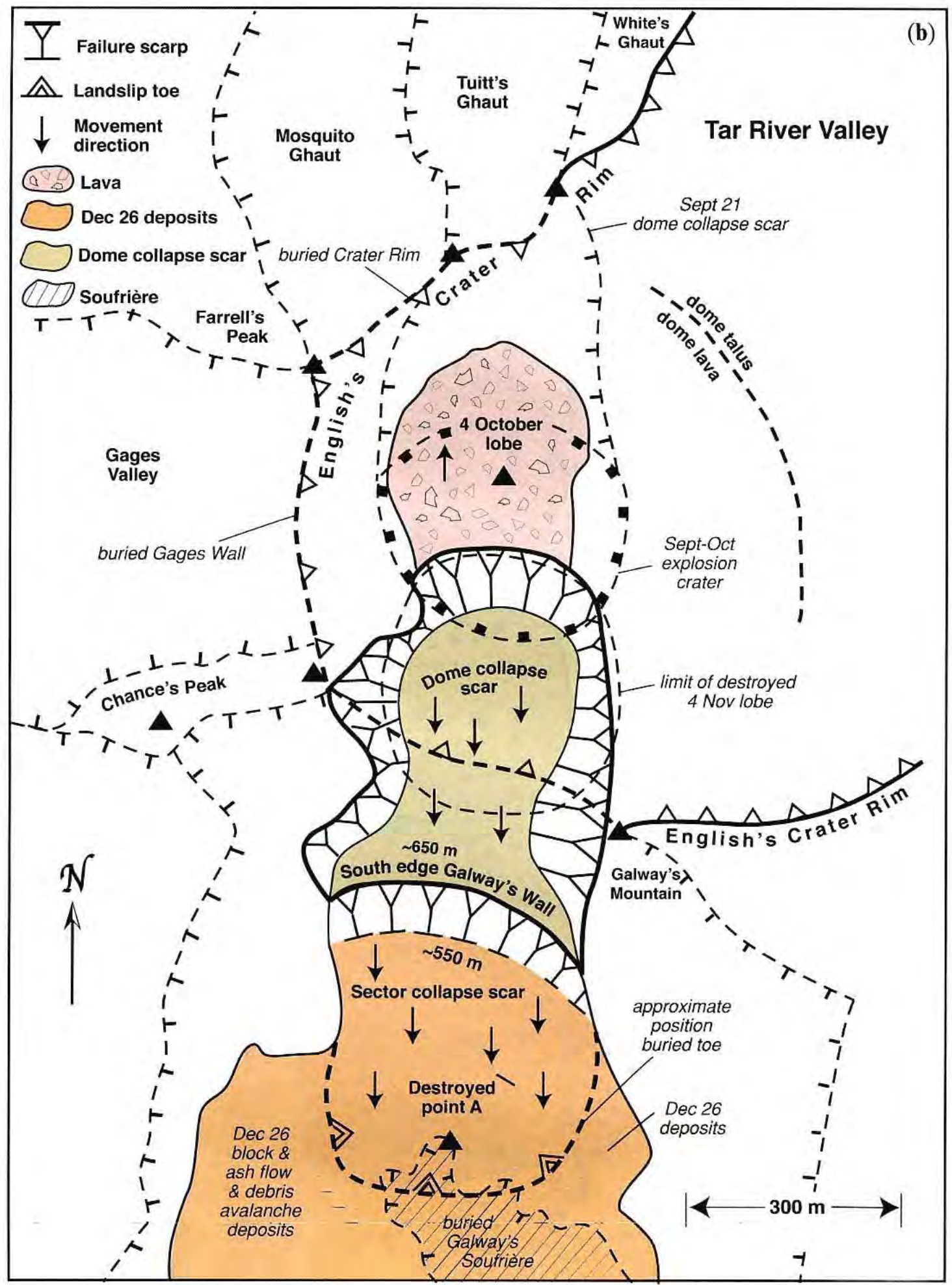

Fig. 9. (continued) 


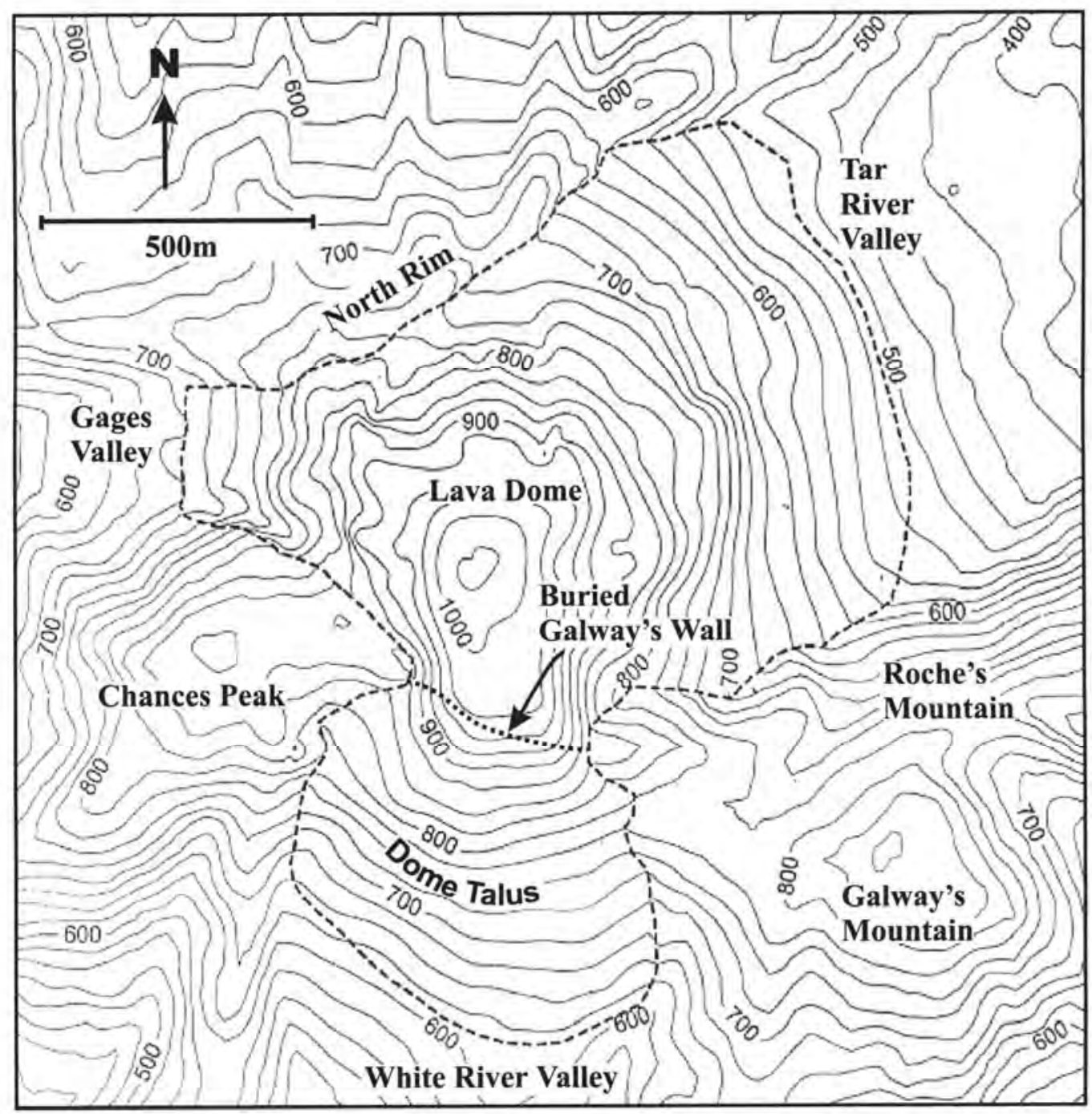

Fig. 10. Topographic map of the Soufriere Hills dome complex just before the 26 December collapse (after Sparks et al. 2002). Area inside the dashed line was subjected to frequent topographic changes associated with dome growth and destruction. Elevations in metres.

The White River valley narrows at Fergus Mountain, about $1.5 \mathrm{~km}$ from the source and $3 \mathrm{~km}$ from the sea. There, the valley bends to the SE, and another, sharper bend to the south occurs above Morris' village, at about $2 \mathrm{~km}$ from the sea (Figs 14 and 15). The avalanche spilled out over the west valley wall at the second bend, emplacing deposits that extended nearly to Morris' (Fig. 19). A similar but smaller deposit spilled over the east valley wall, depositing a perched levee on the sloping flank of Fergus Mountain. These avalanche overspill deposits were detached from, and were 50-80 m higher than, the surface of the main avalanche deposits within the valley.

Most of the avalanche deposit was cool to slightly warm upon emplacement, according to the first inspections a few days after emplacement (Sparks et al. 2002, table 2). However, some localized hot areas and fumaroles within the avalanche deposit were still active more than two years after emplacement; some reflect the activity of fumarolic areas buried by the deposit, but others appear rootless and reflect hot material in the deposit.

\section{Debris avalanche textural facies and map units}

The debris avalanche deposit comprised a chaotic mixture of hydrothermally altered material, variably weathered volcanic breccias and volcaniclastic deposits, and fresh andesite rubble. Each of these types of materials was characterized by one or several distinctive colours, and thus some individual hummocks were of a single colour that indicated a homogeneous material, whereas at others, colour-mottling, lenses or patches were typical and indicated juxtaposition of different lithologies. In general, the hummocks were composed of fragments of source material that had been transported in a relatively intact, although to a variable extent disturbed, fashion. In Glicken's $(1986,1991,1998)$ terminology such deposits, in which a vestige of the original stratigraphy or structure can be preserved, are referred to as avalanche block facies. In this paper we use the slightly modified term avalanche megablock facies or, more simply, megablock facies, in order to avoid possible confusion with the pyroclastic block-and-ash flow deposits that also occur on Montserrat. We use the term matrix facies for that unconsolidated part of the avalanche deposit in which original constituents have been completely mingled, e.g. completely disaggregated source material and entrained loose debris, conceivably containing most types of rock from the source area (Glicken 1998; Ui \& Glicken 1986; Crandell et al. 1984; Ui et al. 2000). Fragments in both of these end-member facies typically are angular, and form unstratified, poorly sorted breccias and gravels. In order to avoid confusion, in the discussion that follows we reserve the term facies to general textural descriptions of avalanche deposits; we use the term unit to refer to the avalanche deposits we have mapped.

The Boxing Day debris avalanche deposit primarily showed typical avalanche megablock facies, with stratigraphically coherent domains affected by localized crushing (Figs 20 to 22). With increasing distance from source, the avalanche deposit displayed increasingly common development of shearing textures and limited mingling of lithologies on a small scale. Shearing textures were 

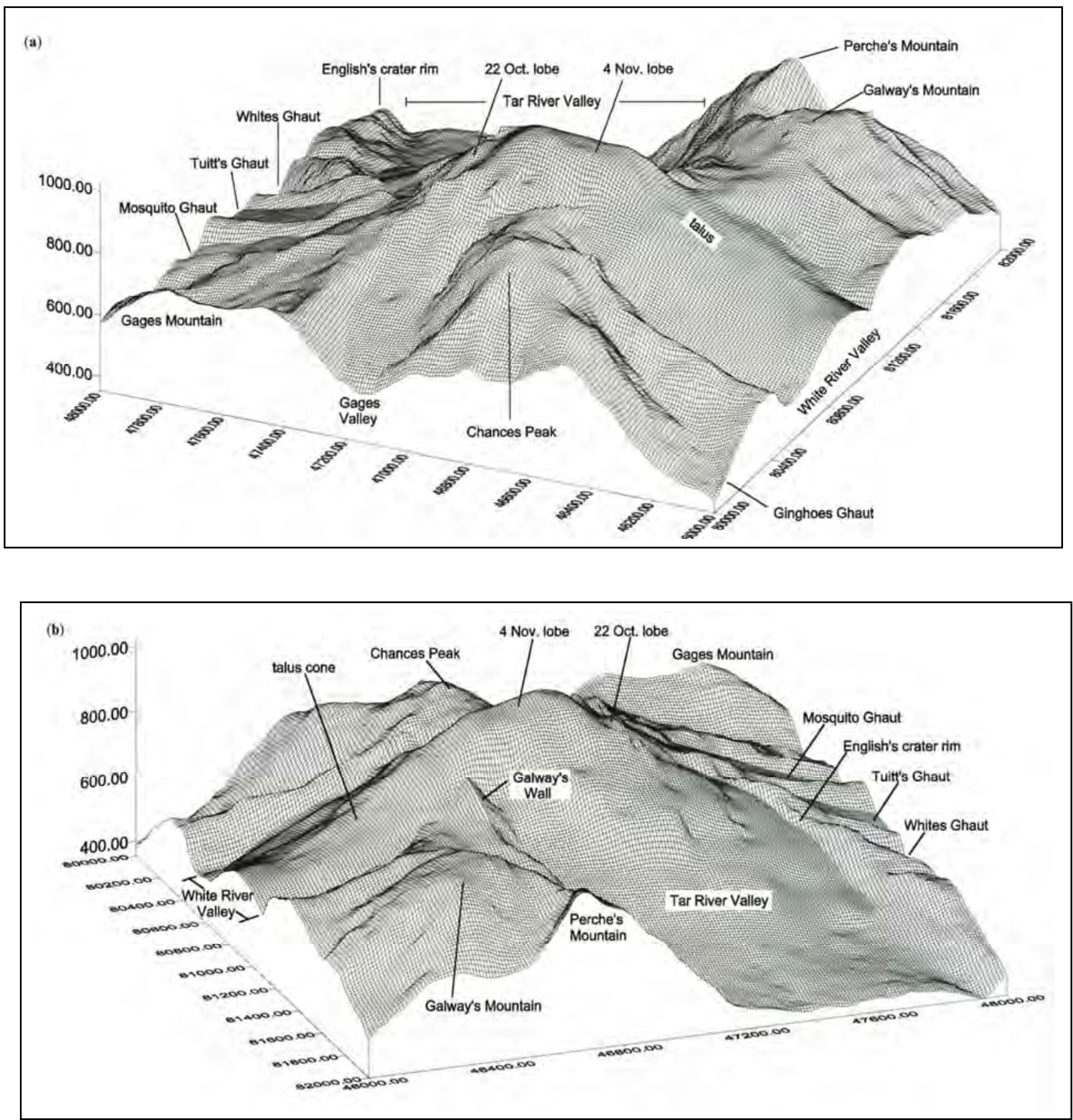

Fig 11. Digital elevation blocks of Soufriere Hills Volcano, pre-26 December 1997. Montserrat grid numbers are shown for reference. Note complex topography of summit area, (a) View N065, tilt 25 degrees, (b) View N290. tilt 20 degrees.

prominent at the base of avalanche megablock domains but were rarely exposed. Also rarely, the deposit displayed matrix fcies, with homolithologic blocks set in a chaotic, very poorly sorted matrix, with clasts ranging from sand size to single lava blocks of 1-2 m diameter. Generally, the clasts consisted of both hydrothermally altered material from the old edifice, and dome lava incorporated from dome talus or parts of the collapsed active dome. Sparse clasts represented material from the hydrothermal plumbing system, often containing numerous fractures filled with gypsum, silica or sulphides. The marked colour and tcxtural variations of the debris avalanche deposit represented different source rocks and alteration zones. The main altered-rock types included (1) bleached white deposits with gypsum and amorphous silica, (2) orange-yellow deposits, (3) reddish-brown deposits, and (4) yellowish-green deposits with pyrite and relict hydrothermal pore fluids. In general, types (1) to (4) may have constituted a succession at the source reflecting increasing depth, from young to old, and/or distance from the locus of alteration. The white deposits evidently were originally near the ground surface at Galway's Soufriere (cf. Figs 21 and 4). They contain mud-cracked palaeosols, relict roots and caliche surfaces with embedded branches, bent metal wires and even portions of the steel cable that formerly ran from Galway's Soufriere to Chances Peak. We identified and have mapped three main lithofacies of the debris avalanche deposit (Fig. 19). These are, informally, the Fumarolic Unit (with two subunits), Halo Unit and Talus Unit. The deposit is spatially divided into White River-channel and overspill elements, with the channelled deposits described as distal or proximal, respectively below and above the Fergus Mountain narrows 
(a)

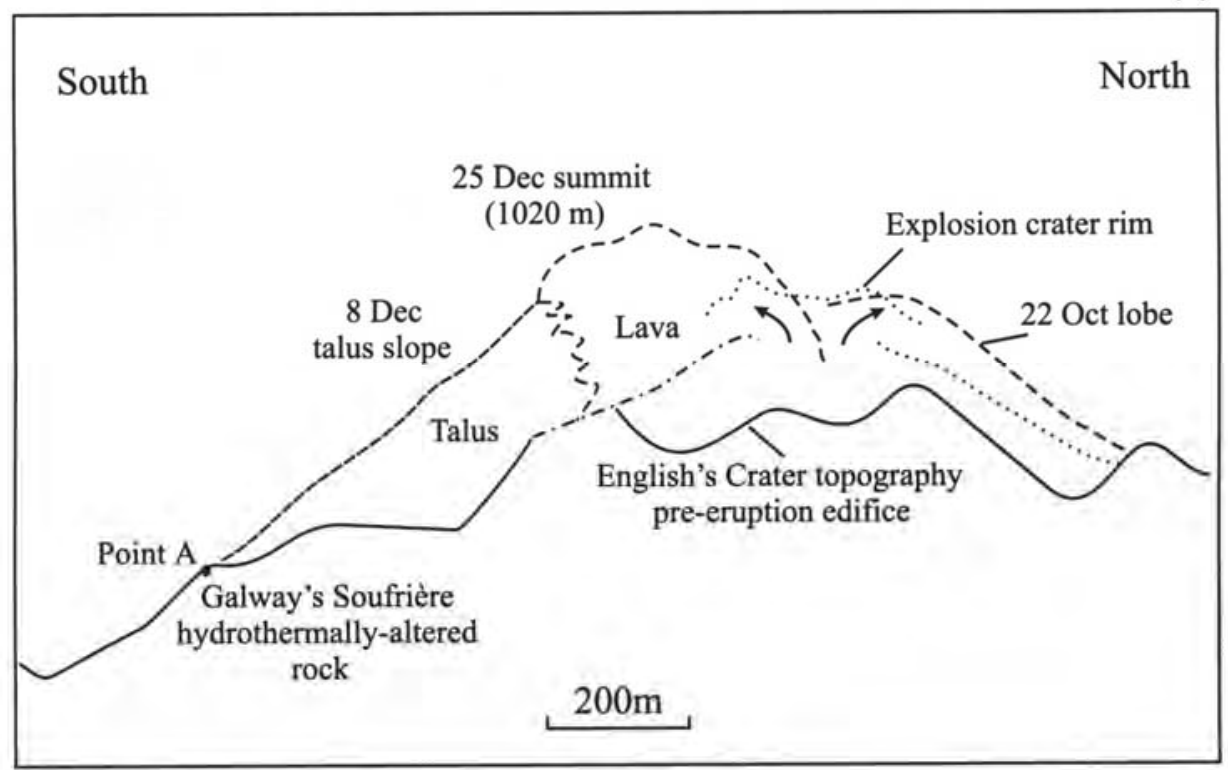

(b)

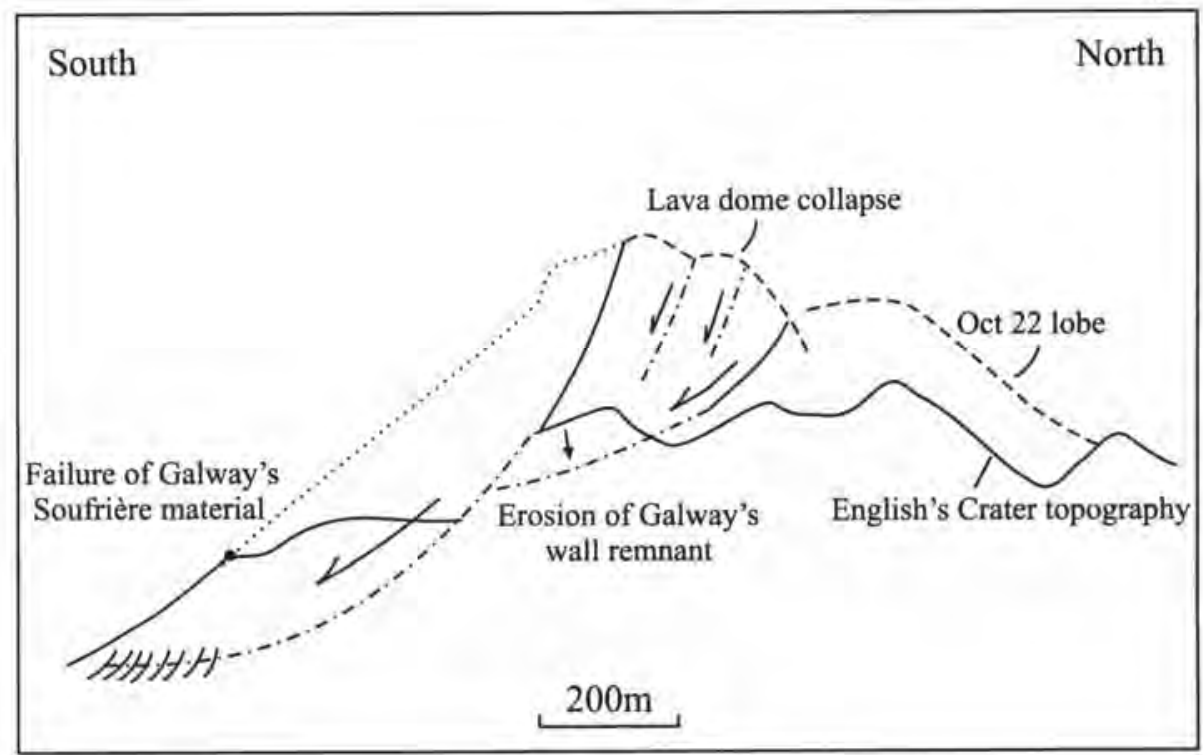

Fig. 12. Cross-sections through Soufriere Hills Volcano, from north to south. (a) before and (b) after the 26 December 1997 collapse (cf. Fig. 9). The pre-eruption conditions included English's Crater and Galway's Soufriere. Additional materials comprise lavas, and talus and rockfall debris. In (b), the collapse first involved talus and some dome lava (dotted line), and underlying soufriere material, followed by explosive collapse of oversleepened, decompressed fresh dome lava, which led to generation of an energetic pyroclastic current. The positions of the failure planes are schematic.

region (Figs 14 and 19). There are two overspill deposits: the western one near Morris', and the eastern one perched on the flank of Fergus Mountain.

The Fumarolic Unit was subdivided into two parts. The Soufriere Subunit comprised superficial deposits with materials showing intense epithermal alteration, derived originally from the Galway's Soufriere area (Fig. 4). The Soufriere Subunit constituted the white, orange or yellow suites (1 to 3 as described above) within the avalanche deposit, in texturally diverse deposits that ranged from matrix-rich lithified breccias to clast-supported unconsolidated breccias. The colours mainly reflected the original mineral associations observed in the highly acid, oxidized superficial part of the hydrothermal system of Galway's Soufriere, but may have also reflected stratigraphy or burial depth. Primary magmatic minerals were replaced by silica polymorphs, titanium oxide and sulphates (such as natroalunite. natrojarosite, gypsum and anhydrite) (Boudon et al. 1998; Chiodini et al. 1996). These are the typical alteration products of unsealed acid-sulphate systems. Kaolinite, smectite and mixed-layer clay assemblages formed locally, with less acidic solutions (Boudon et al. 1998].

Large patches of yellowish-green material (type 4) were located near the Fergus Mountain narrows and more proximally in the upper White River valley (Fig. 20). These were distinctive enough to map and are referred to as Chartreuse Subunit (Fig. 19). This material was inferred to represent the deeper, less-oxidising parts of the hydrothermal system, where magmatic or other influences created reducing conditions. We inferred that the colouration was due to reduced iron and sulphides, but detailed mineralogical and chemical studies have not yet been completed.

The fact that locally there are repeated slices of avalanche material with stacked coloured alteration types suggests that a layered hydrothermal system existed that was intersected by the 

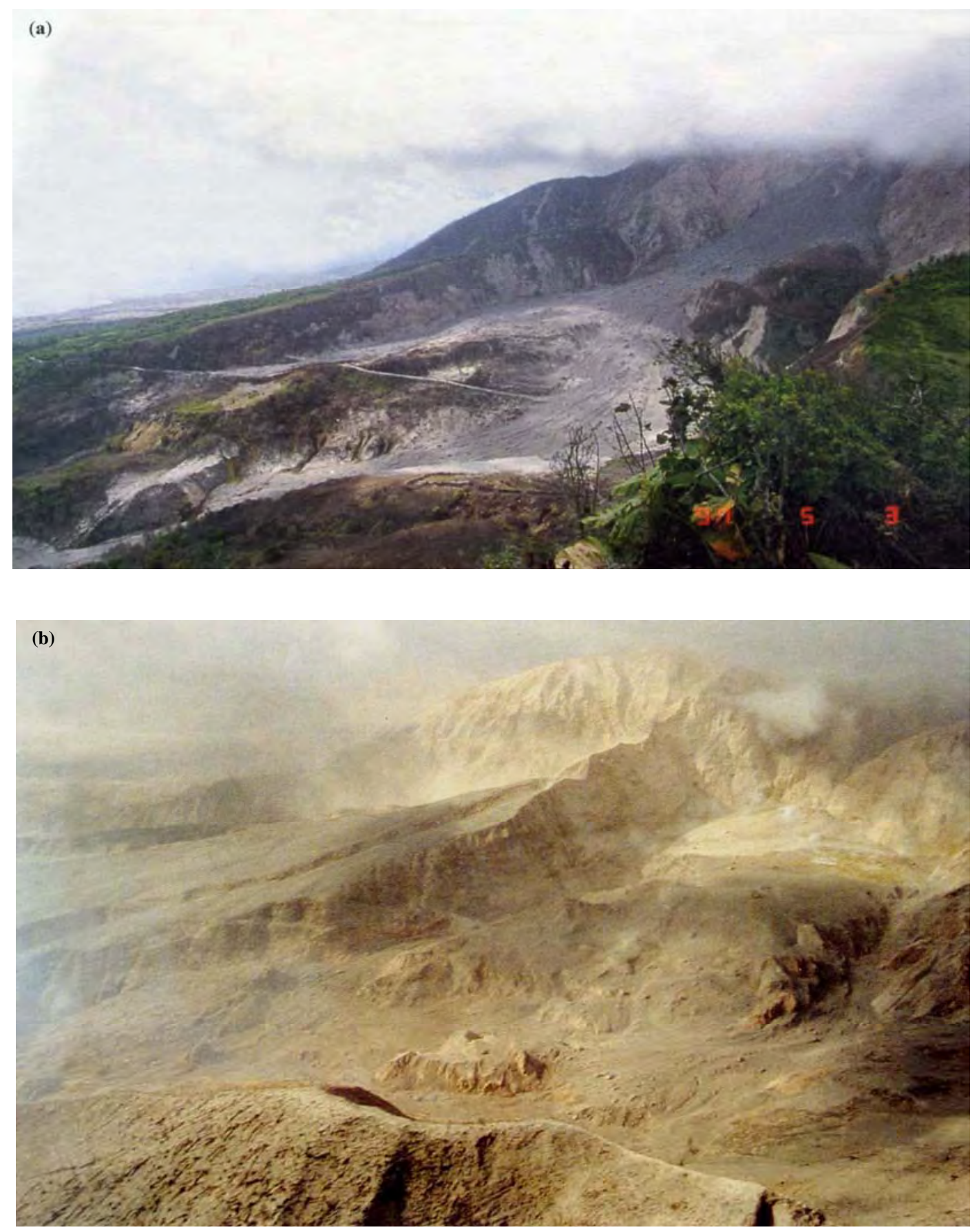

Fig. 13. Proximal part of White River valley, north of Fergus Mountain, (a) By 3 May 1997, the valley and soufriere were filled by block-and-ash flow deposits from lava dome collapses, and these deposits also partly blanketed the bedrock shelf west of the river channel, where, at the foot of the western escarpment, they reached the access road to Galway's Soufriere (photo MVO). (b) View on 30 December 1997, showing hummocky Boxing Day debris avalanche deposits (photo MVO). Fergus Mountain is in foreground, with the entire landscape dusted with tephra from the Boxing Day pyroclastic density current and associated ash cloud. Avalanche megablocks protrude from valley deposits. Yellowish coloration in deposits at right centre reflects fumarolic encrustations in deposits that have buried the decapitated Galways Soufriere. Beyond this, the sector collapse scar rises at Galway's Wall, with the notch in the wall leading to the dome collapse scar (sec Fig. 9b).

collapse slip surface. As a result, the avalanche flow deposit in general displayed a vertical alteration order, with Chartreuse Subunit overlain by Soufriere Subunit materials. This suggests that depth of origin was a locally dominant factor in alteration zoning, although the spatial distribution of alteration could also be influenced by conditions that varied laterally as well as vertically (Giggenbach 1992).

An irregular lower-intensity alteration halo was known to surround the soufriere and its substructure for several hundred metres, extending especially in the direction of English's Crater (Boudon et al. 1998). The term Halo Unit was used to describe the avalanche materials from this source, which were characterized by less alteration than in the Fumarolic Unit. The primary sequences comprising the Fumarolic and Halo units may have been originally similar, with the distinguishing characteristics simply reflecting the degree of alteration. In the avalanche deposit the Halo Unit materials were typically grey, tan or brown consolidated breccias and tuffs, similar to rocks that were exposed in Galway's Wall and in 

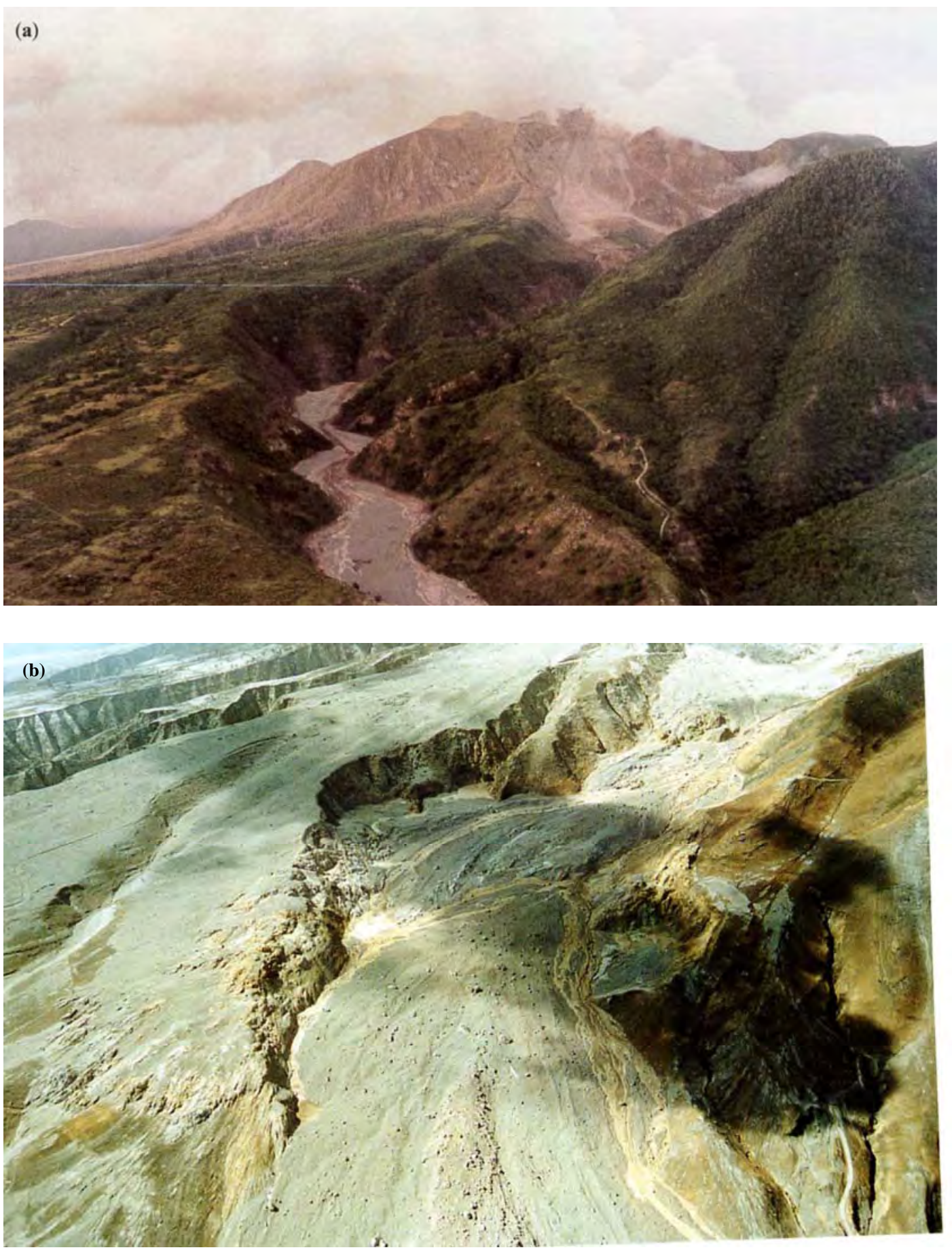

Fig. 14. Medial part of White River valley, viewed north, (a) 22 April 1997, with valley partly filled by block-and-ash flow deposits and materials reworked by lahars. Fergus Mountain at right, Morris' area to left on west bank. Soufriere Hills Volcano in background (photo K. West). Considerable additional filling occurred later (see Fig. 18a). (b) Boxing Day debris avalanche and coarse pyroclastic density current deposits mainly followed the drainage of the White River, but parts of these flows ramped over the western valley wall, toward Morris'. June 1998 (photo J.C.K.). Two prominent flow fronts in the avalanche deposit suggest two pulses of overspilling debris. On the opposite bank, the avalanche left a levee-like deposit of blocky avalanche debris on the flank of Fergus Mountain. Vegetation in (a) was removed by the violent pyroclastic density current, the grey deposits of which blanket the landscape in (b).

the hill of layered tuff between this and Galway's Soufriere (Fig. 5). These sites were located between Chances Peak and Galway's Mountain (Fig. 2), which constituted two of the five hornblendehypersthene dome complexes that formed the superstructure of Soufriere Hills Volcano (Rea 1974: Roobol \&Smith 1998). The sequences in the vicinity of Galway's Wall derived from both complexes and mainly comprised block-and-ash flow deposits (MacGregor 1952; Rea 1974; Roobol \& Smith 1998). The deposits in the hill between Galway's Wall and Galways Soufriere dipped northward (Fig. 5). We speculate that the hill might represent a slump block from a prehistoric sector collapse. The interpretation is supported by the sense of slip on faults, the broad, amphitheatre-like valley morphology, and the recognition of probable old debris avalanche deposits in the White River valley and offshore from its mouth. If so, its slip surface was probably reactivated in the 1997 sector collapse.

The Talus Unit comprised fresh, grey to reddish oxidized subangular breccia, representing mainly the talus cone of the 1997 dome lava that comprised part of the collapsed sector (Fig. 20d). Because the talus was mostly umconsolidated and of non-cohesive particles, its clast assemblages could not have remained intact as coherent megablocks. Neither, in general, were they thoroughly mingled with other material by the avalanche emplacement processes. Thus, 

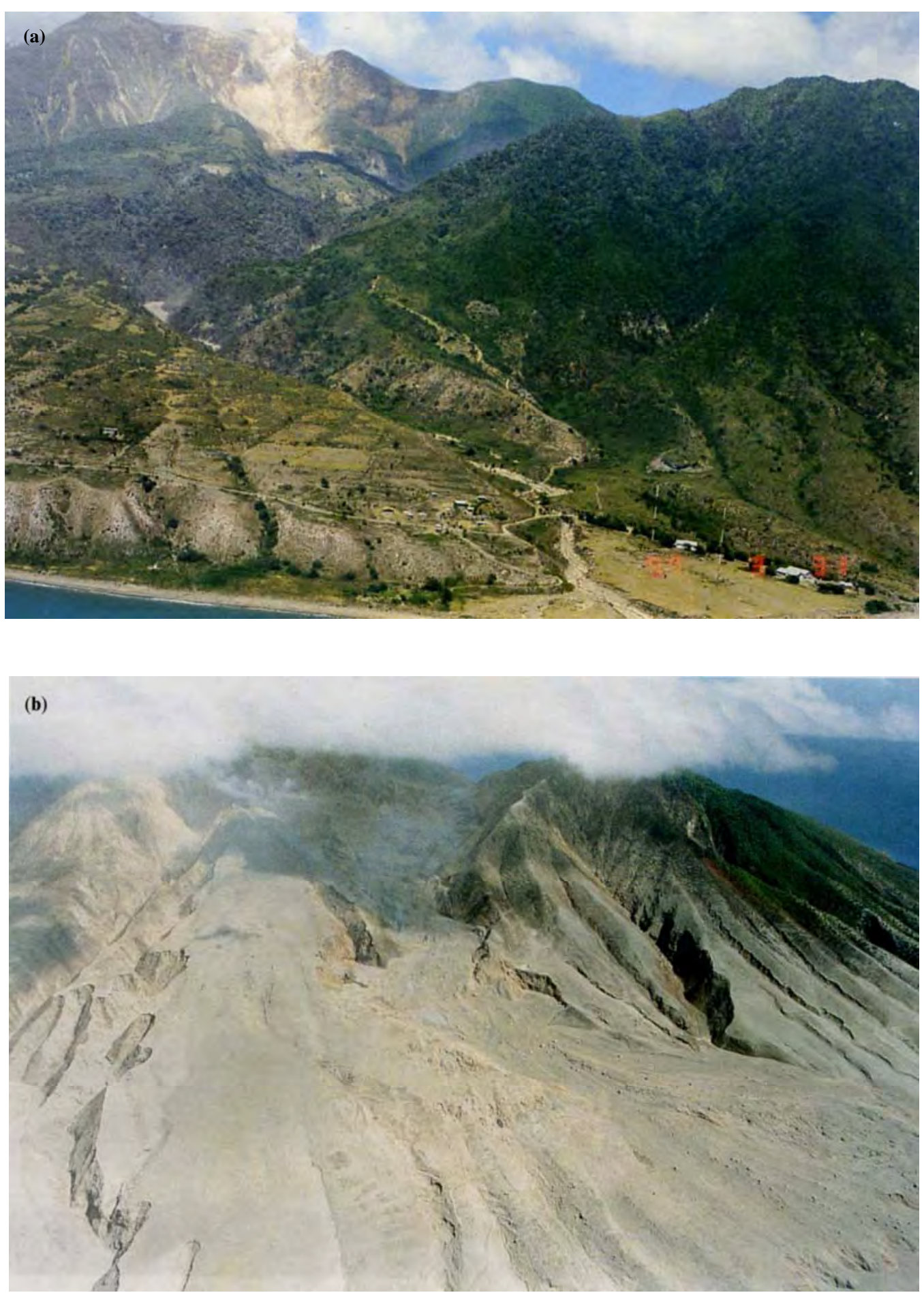

Fig. 15. Distal part of White River valley, (a) Mouth of White River at Old Fort Point on 31 March 1997. Morris' on left, Fergus Mountain and South Soufriere Hills on right, Galway's Wall in distance (photo MVO). (b) Same area a few days after 26 December 1997, with river valley containing deposits from the debris avalanche and coarse facies of the pyroclastic density current (photo MVO). Overspill deposits were emplaced above Morris' in foreground. Vegetation and buildings were largely destroyed by the violent pyroclastic density current, with its monochromatic grey tephra covering the landscape.

these deposits were neither avalanche megablock facies nor matrix facies in the original senses of these terms, but represented a new avalanche textural facies type. We designate it generically as non-cohesive facies, defined as part of a debris avalanche deposit comprising originally non-cohesive source material. We speculate that rapid avalanche motion may have been complex, inasmuch as cohesive altered materials probably had deformation and transport properties quite different from cohesionless debris.

Some intact dome lavas were originally interleaved with upper parts of the talus and therefore were included in the avalanche deposit, but they would be difficult to distinguish from talus. Most of the fresh dome lavas from the northern scar were presumed to have become involved in the pyroclastic density current on Boxing Day (Sparks et al. 2002; Ritchie et al. 2002). However, discrimination of the coarse valley facies of the pyroclastic density current deposit from the Talus Unit of the avalanche deposit was sometimes difficult, because the source for both deposit types was practically identical. Furthermore, unconsolidated loose talus in the avalanche deposit was reworked and entrained in the energetic pyroclastic density current, and this reshaped the surface morphology of mounds of talus over which it passed. Mapping of generally undifferentiated blocky lava deposits is shown on Figure 19. 


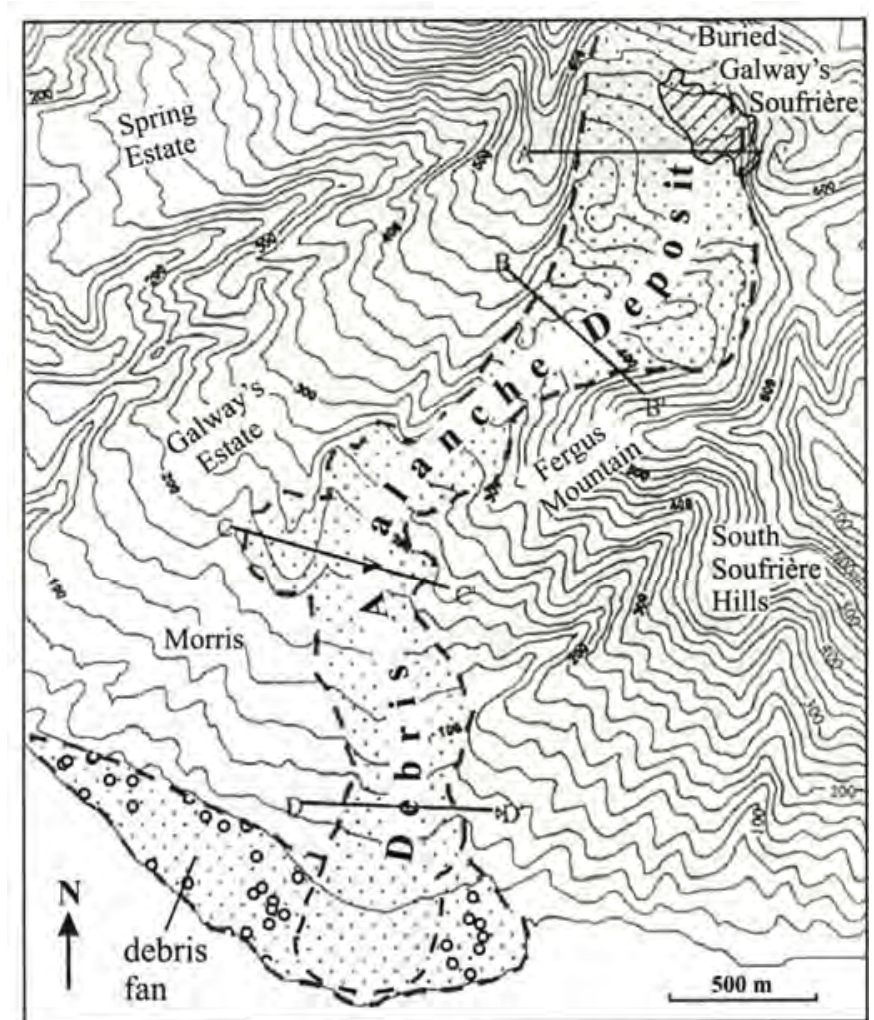

Fig. 16. Topography of the White River immediutely after the 26 December 1997 collapse, based on surveys on 4 and 17 January 1998 (data from R. Herd).
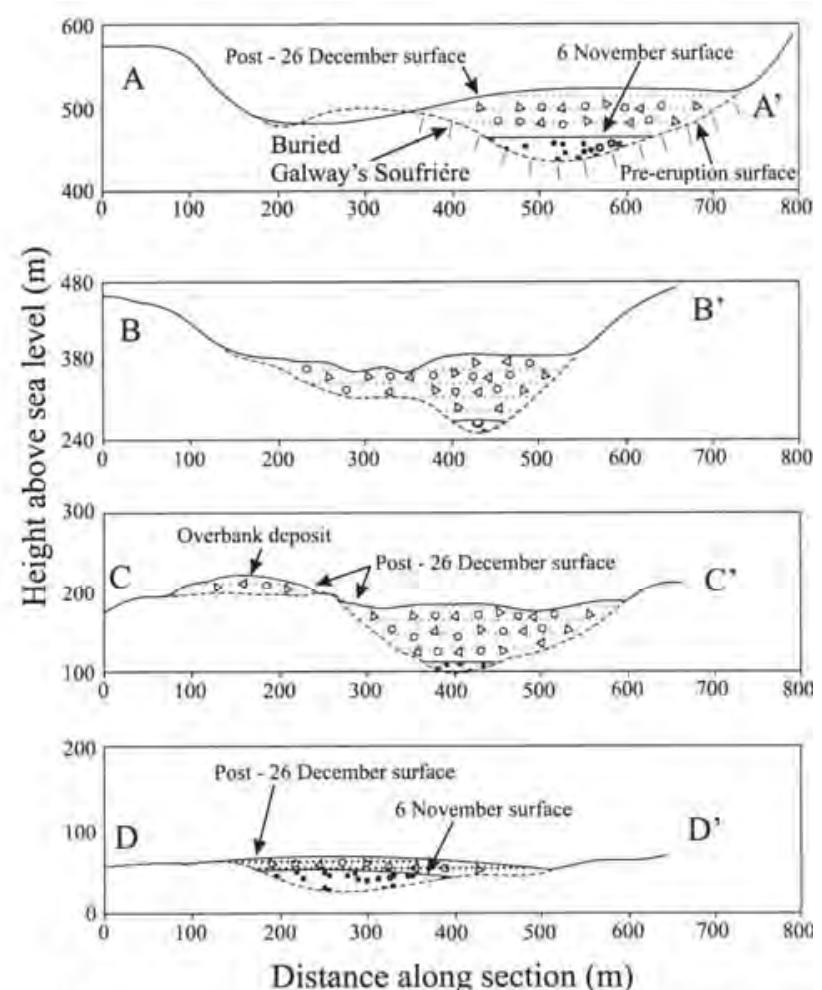

Fig. 17. Transverse cross-secrions across the White River valley show the original topography (dashed lines). the infill of material from all earlier eruptions, including the 4-6 November 1997 pyroclastic flow deposits (lower solid line), and the infill of deposits from the 26 December 1997 collapse and explosion (upper solid line).

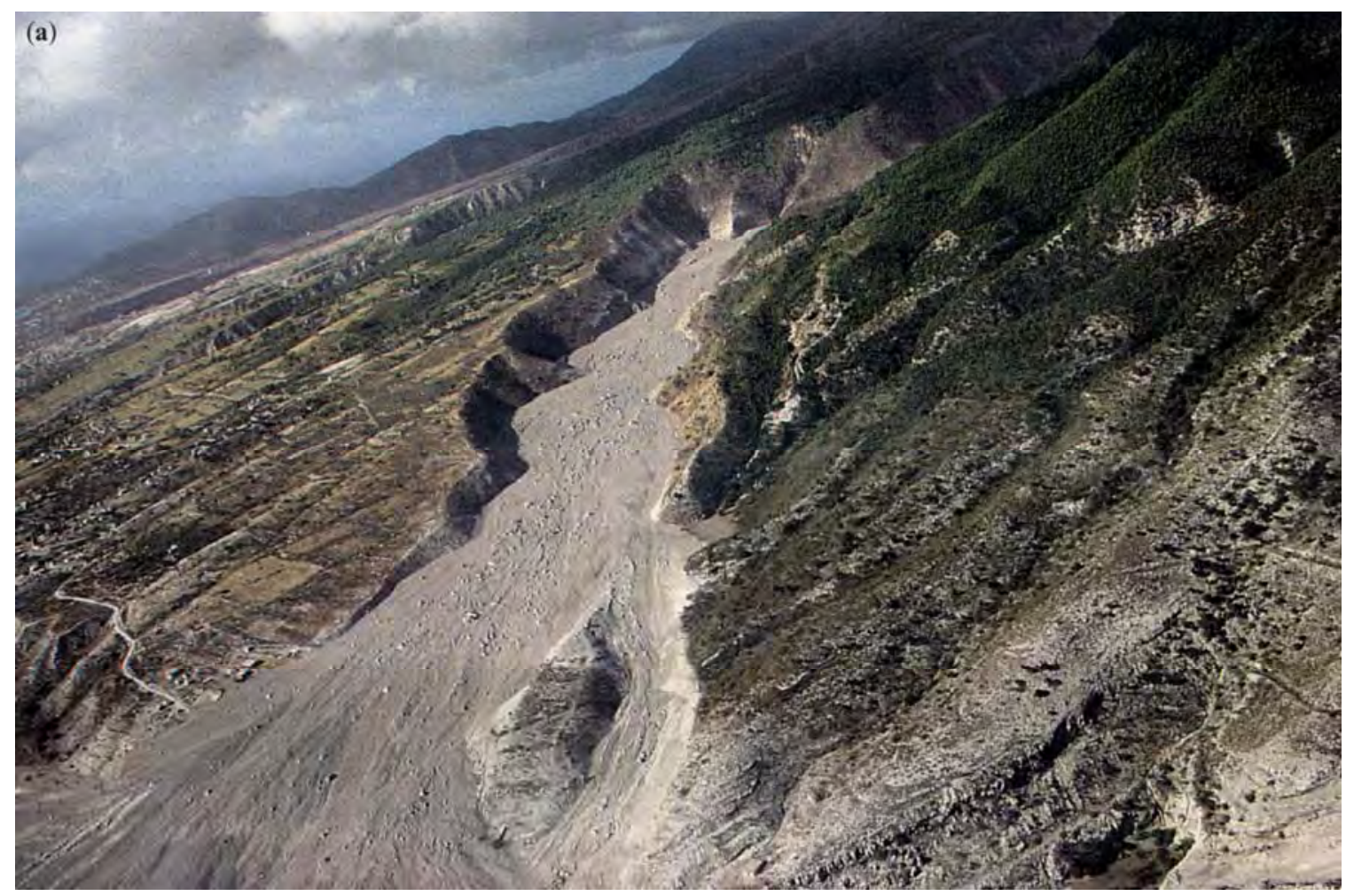

Fig. 18. Comparative panoramic views of distal White River valley, (a) View in early December 1997, three weeks before the collapse. Fergus Mountain flank to right, villages of Morris' and St Patricks to left. Channelled block-and-ash flow deposits are derived from dome collapses on 4 and 6 November 1997. Note island surrounded by pyroclastic deposits al lower centre, representing a bedrock ridge from the original landscape (cf. Fig. 15a). As discussed below, this ridge influenced avalanche deposition on Boxing Day (photo B.V.). (b) Same area on 2 June 1998, showing debris avalanche deposit extending over fan nearly lo the sea (photo J.C.K.). The current of avalanche debris in the central channel had continued in motion, while the eastern pan came to rest on the ridge within the channel shown in (a). As this main current thinned, larger blocks became grounded, and a sheet-like deposit was formed at the avalanche terminus, with sparse, small hummocks, (c). Structure in distal lobate, hummocky avalanche deposit, June 1998 (photo J.C.K.). Eastern part formed a series of stacked lobes where the flow grounded against the ridge within the channel in (a). Course pyroclastic density current flow lines diverge about avalanche deposit. Overspill deposits at Morris' at upper left. 

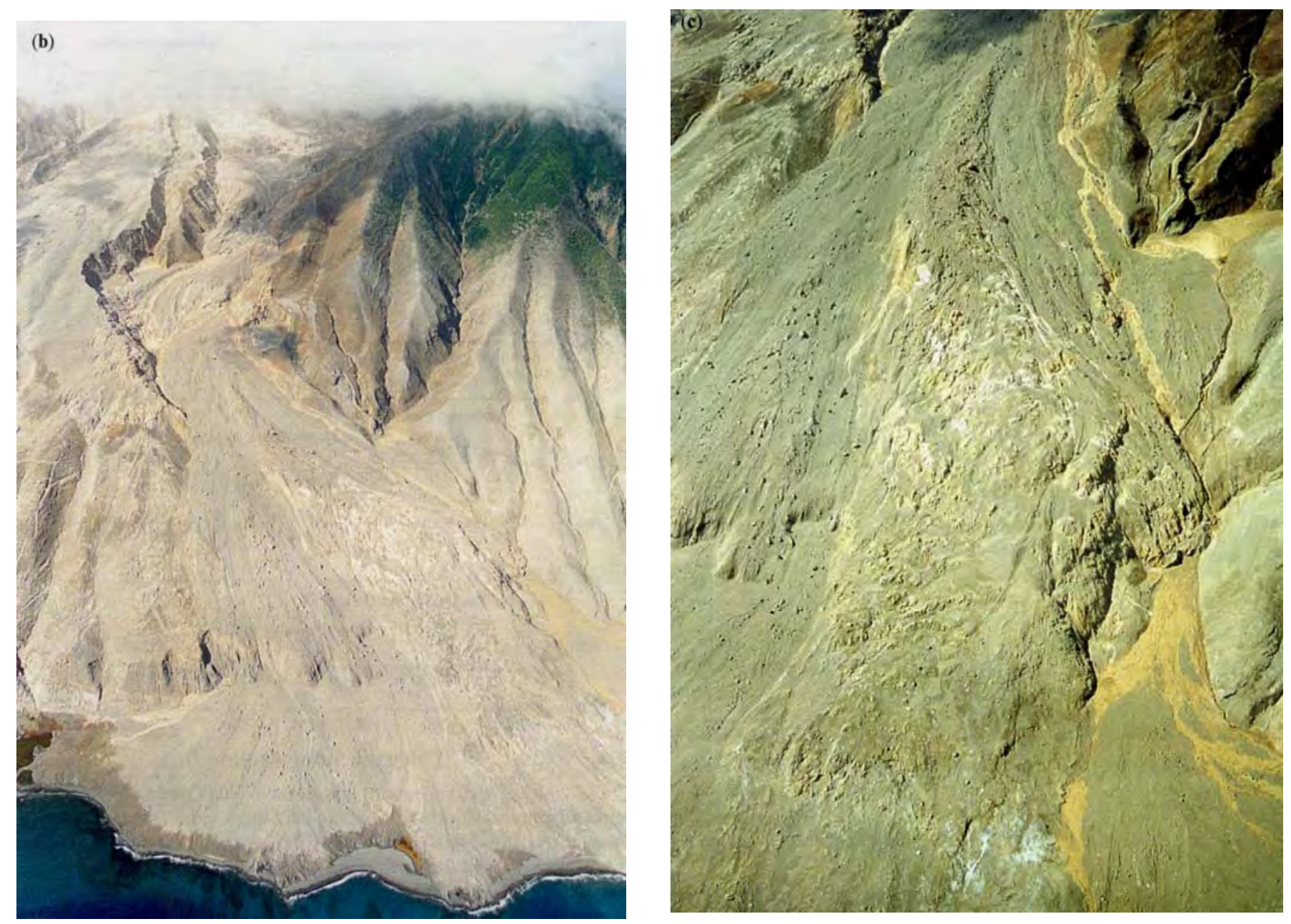

Fig. 18. \{continued)

The volumetric proportions of the various units could not be determined from the non-dissectcd surface exposures alone, and the distribution of units at depth in the deposit is not yet known.

\section{Surface relief, deposit morphology and composition, and structures}

The surface relief of the debris avalanche deposit, together with its internal geological fabric, provided information about the processes of avalanche formation, emplacement and deceleration. We distinguished three classes of primary surface features, which resulted from: (I) the incomplete disintegration of the failed part of the edifice; (2) avalanche transportation; and (3) avalanche deceleration and deposition.

Hummocks are the characteristic morphologic feature of volcanic debris avalanche deposits (Voight el al. 1981; Siebert 1984, 1996; Glicken 1986. 1998; Ui \& Glicken 1986; Ui et al. 2000). At Soufriere Hills, hummocks over 100 m wide protruded 0.5-30 m above the mean elevation of the debris surface, and were commonly bounded by slumps or faults (Figs 13 and 20). Closed depressions as much as $50 \mathrm{~m}$ across and $20 \mathrm{~m}$ deep were also common features, although most such areas tended to be filled by younger deposits. Details for most hummocks in proximal areas were unrecorded, because safety considerations precluded close inspection. These constraints remained in effect throughout the year 2000. Many hummocks were buried or reshaped by later events. Occasional pyroclastic flow activity continued in the valley into 1999, and numerous severe storms occurred, so that intermittent severe erosion and redeposition have strongly modified the exposures and surface morphology of the avalanche deposit. The lack of detailed new topographic maps over the debris avalanche deposit has impeded semi-quantitative morphological analyses of the numbers, shape orientation and size of hummocks.

The largest hummocks occurred in the upper White River valley $(<1.5 \mathrm{~km}$ from source, north of the Fergus Mountain narrows), where they protruded above smooth-surfaced blocky pyroclastic flow deposits (Figs 13 and 20). Qualitatively, the scale of hummocky relief decreased down-valley, and individual hummocks in the distal area were more numerous, smaller, and less sharp-edged than those in the proximal region, with surface relief about 2-10 m (Fig. 21). In comparison, the steep frontal snouts of distal flow lobes were typically about $1020 \mathrm{~m}$ high (Figs 1, 18 and 21a). The change in surface morphology reflected the increasing damage sustained by the avalanche debris in moving down-slope and in squeezing through the Fergus Mountain narrows. Both distance of transport and time elapsed in transport may have been factors contributing to increased disruption. In the thinner, laterally spread, most-distal portion of the avalanche deposit that extended to within $20 \mathrm{~m}$ of the coast, numerous, increasingly separated hummocks, $2-5 \mathrm{~m}$ high, occurred, with each dominated by one or more of the main coloured lithologies.

Some large proximal hummocks (overall $>100 \mathrm{~m}$ wide, c.50m high) appear to be overlapping, rotated slide blocks containing relatively little-disturbed pre-collapse stratigraphy (Fig. 20a). These were similar to the toreva blocks of Reiehe (1937), reported also from other volcanic debris avalanche sites (Wadge el al. 1995; Francis \& Wells 1987; Belousov el al. 1999), and may have reflected retrogressive failure of large fragments of the edifice, including Galway's Wall. The spatial position of these hummocks, and the 


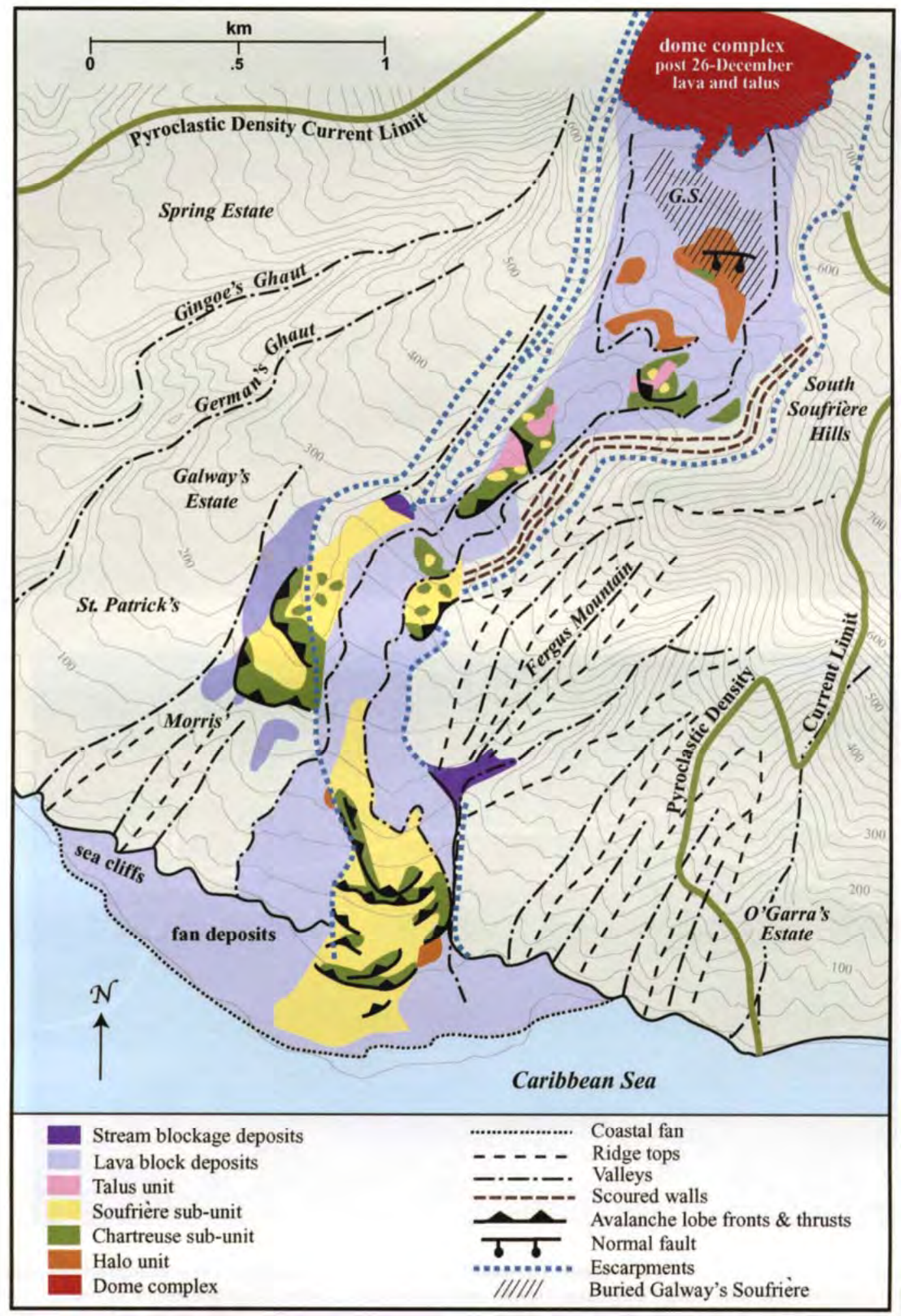

Fig. 19. Map of debris avalanche deposit showing map units and surface features.

fact that fumaroles on some were still active, suggested that they represented the least disrupted, but still moved, portions of the former Galway's Soufriere and surrounding alteration halo. Some fumaroles in avalanche debris over the site of the old soufriere may have masked hydrothermal systems that were still active, but in other cases, south of the former position of the soufriere, the fumaroles appeared to be rootless. At one location (location 1-3, Fig. 23; near Fig. 20a). lava talus overlying a rootless fumarole set in a megablock of Chartreuse Subunit material had been cemented by fumarolic sulphate precipitates.

Other hummocks were bounded by normal faults and appeared to represent the horsts of simple extensional systems (Fig. 20c), reflecting longitudinal stretching (hummock long-axes perpendicular to flow), or transverse stretching (hummock long-axes parallel to flow) (Voight et al. 1981). Structures such us imbricated thrusts or strike-slip faults formed in response to longitudinal compressional stresses. These occurred at channel constrictions (Fig. 20b), overspill ramps (Fig. 22b), in frontal ridges of avalanche debris near Morris' (Fig. 22b,d), and in imbricated flow snouts in distal channel deposits (Figs 18 and 24d).

Field observations suggest that the avalanche thickened locally during flow by the overlapping of successive flow lobes. At the northern part of the narrows, Talus Unit materials occurred in thin lenses between other avalanche units, with the material overlying 

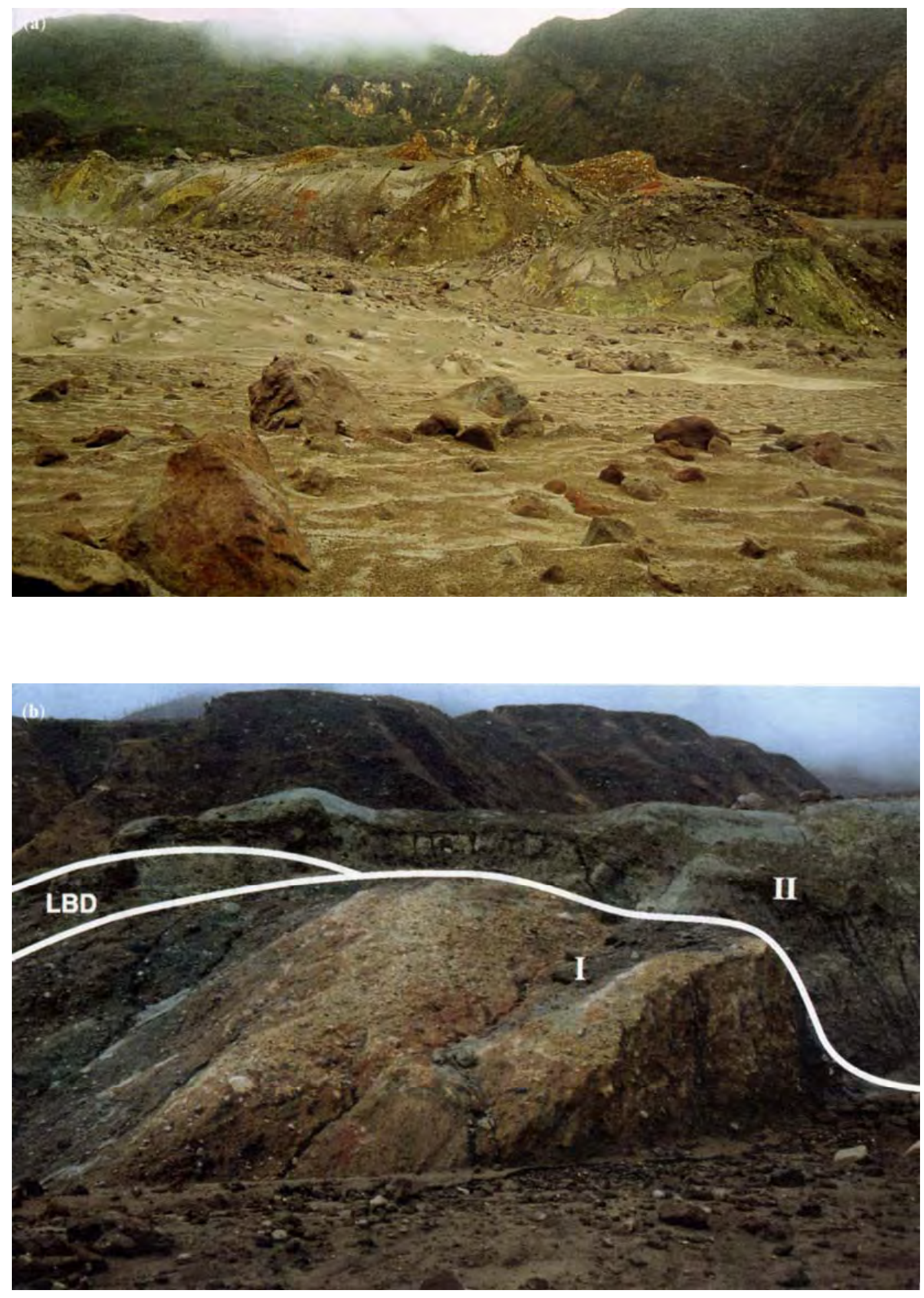

Fig. 20. Debris avalanche morphology and structure in proximal and medial regions, (a) View towards east at overlapping tilted avalanche megablocks that preserve original stratigraphy, with yellow-green Chartreuse Subunit overlain by reddish brown Soufriere Subunit in June 1998 (photo J.C.K.). Block on right capped by breccia of fresh lava blocks. Active fumaroles within some blocks suggest that these represent moved parts of the Galway's Soufriere fumarolic field, (b) Stacked sequence near Fergus Mountain narrows in June 1998 (photo J.C.K.). Oxidized Soufriere Subunit pyroclastic breccia (I) overlain by a lens of lava block deposits (LBD), in turn overlapped by Chartreuse Subunit breccia ( I I ). (c) Avalanche megablock facies at foot of Fergus Mountain overspill, June 1998 (photo J.C.K.). Soufriere Subunit materials. Horizontally bedded rock of Fergus Mountain flank exposed on right, (d) Detail at sample location 1-4,5 (see Fig. 23) of contact between pale megablock facies breccia and adjacent subrounded blocky deposits representing probable Talus unit, in March 1999 (photo A.B.B.).

the talus displaying prominent shear deformation textures in its basal part (Fig. 20b). The observations suggest that decelerating flow due to boundary resistance in the constricted frontal flow lobe led to its being overridden by faster moving material. Other complications in the collapse process, perhaps aided by the constriction at the Fergus Mountain narrows, induced at least three main flow pulses. These mainly followed the drainage of the White River, but parts of the flow ramped over the western wall of the White River valley toward Morris', rather than manoeuvring around the sharp second bend below Fergus Mountain (Figs 19 and 22). Two prominent flow fronts occur in these overspill deposits, which suggests that two pulses of debris partly spilled over the valley walls (Figs 14b and 22d). Conceivably, part of the first flow-pulse may have impacted against the west wall and partly infilled against it (Fig. 22b), thus assisting subsequent flow pulses to surmount the wall. The first overspilling flow reached several 

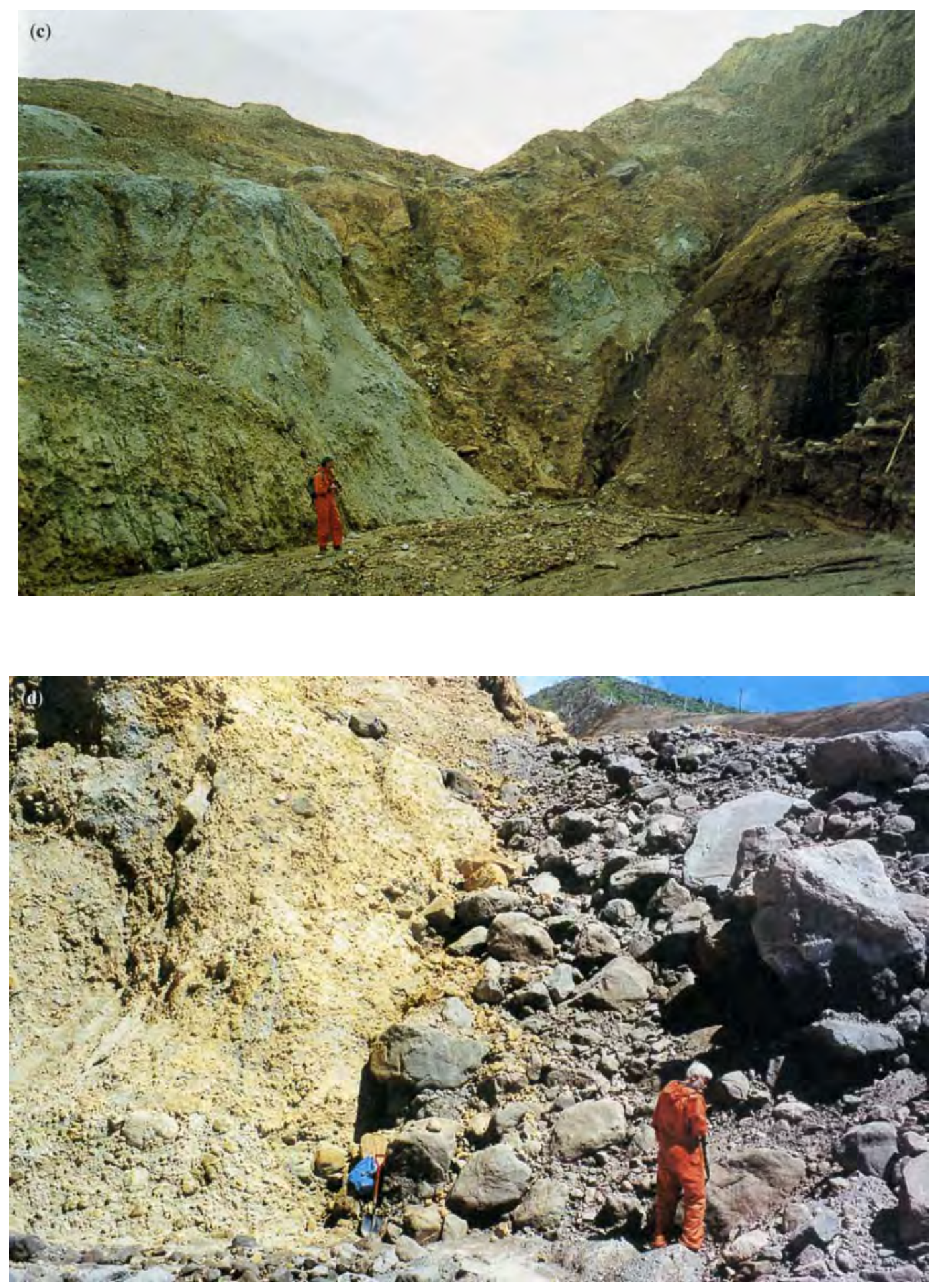

Fig. 20. (continued)

hundred metres into the Morris' area, forming a prominent front, and the second reached a shorter distance, because it was less energetic or because the bank height was effectively raised $c .20 \mathrm{~m}$ by the first dcposit. Each overspill deposit was composed of the typical vertical sequence of altered types (basal yellow-green Chartreuse Subunit, successively overlain by Soufriere Subunit types (3) reddish brown, (2) orange yellow, and (1) upper white (Fig. 22d)). The deposition here was interpreted as representing en-masse freezing of avalanche mcgablock facies materials. Also, at this valley bend, energetic block-and-ash flows from the dome explosion overtopped the White River valley walls, with the deposits extending well beyond the limits of the avalanche deposit (Figs 14b and 22). Some scattered large, pinkish, dense and fresh lava clasts on the avalanche deposit here reflect lag deposition from these energetic flows.
Directly across the valley from the Morris' overspill, the avalanche scoured the wall of the valley and left a levee-like deposit of blocky avalanche debris on the flank of Fergus Mountain (Fig. 19). The 10-50 m thick levee-like deposit comprised mainly megablock facies and represented a single emplacement sequence with the typical green basal Chartreuse Subunit, upper Soufriere Subunit involving reddish-brown and orange-yellow types, and Talus Unit (Figs 20c and 22c). Isolated deformed blocks of the basal green and grey Chartreuse Subunit were scattered over the upper deposit surface, probably reflecting the dynamic impact of the avalanche against the valley walls.

In the distal region, from below the second bend adjacent to Fergus Mountain to about $500 \mathrm{~m}$ from the sea, at least three stacked sets of the main coloured lithologic types occur with preserved older stratigraphy, a hummocky topography (typically 3-10m relief). 

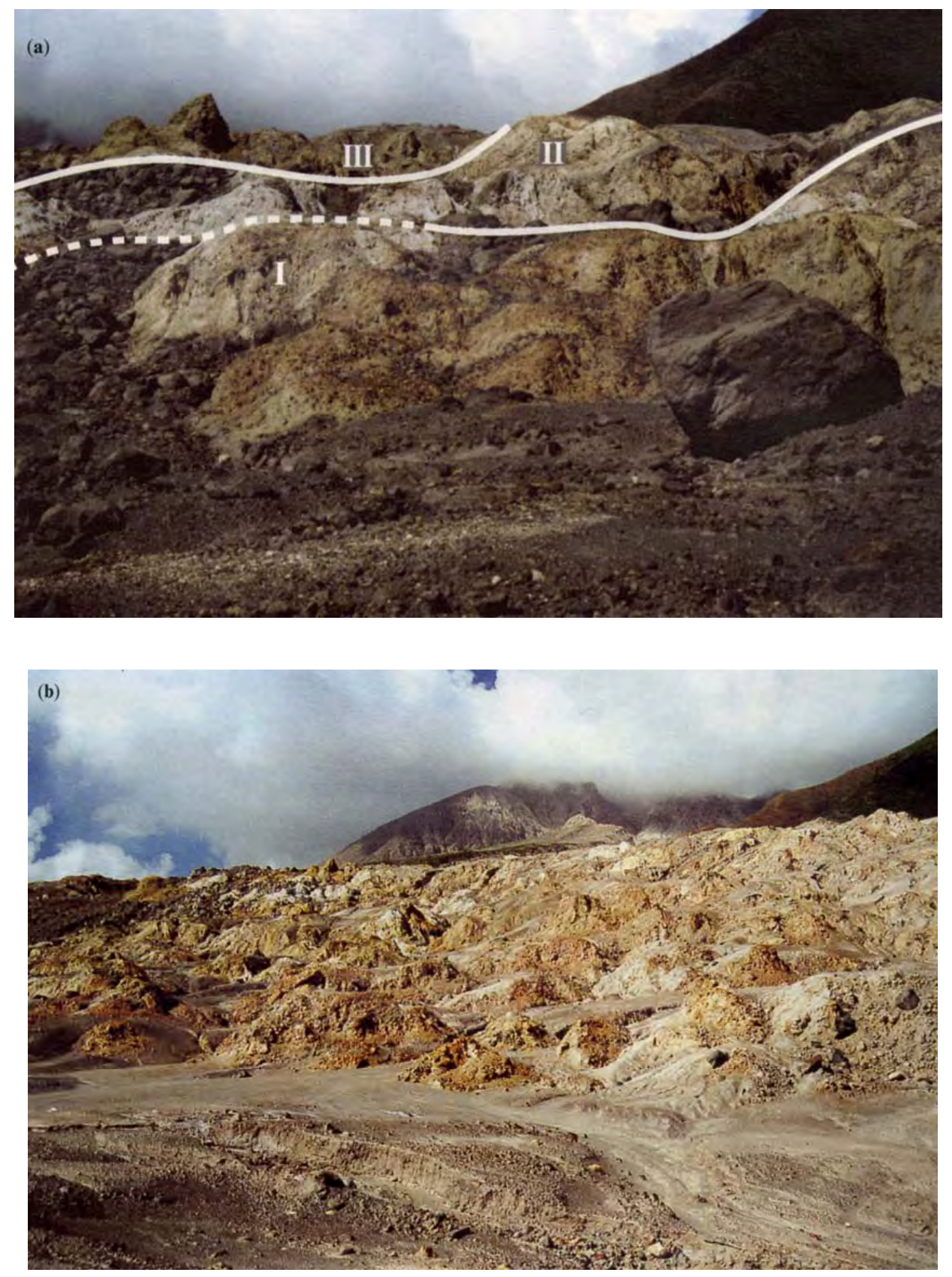

Fig. 21. Debris avalanche morphology and structure in distal region, (a) Stair-stopped sets of the main coloured unit/subunit lithologies. shown by roman numerals, with frontal ridges I 5-20 m high. March 1999. Surface is hummockv with 3-10 m relief (photo J.C.K...I. (b) Distal hummock field in avalanche deposit in March 1999, showing multicoloured lithologies (cf. Fig. 4). Relief 2-5 m (photo J.C.K.). (c) Soufriere Subunit hummock on 8 March 1999, buried by flat-surfaced, coarse Boxing Day pyroclastic density current deposits containing reworked avalanche clasts. Relief 3-4 m. Top surface is covered by fine pyroclastic density current deposits. Near sample location 8-1 (Fig. 23) (photo A.B.B.). (d) Multicoloured hummocky terrain displaying megablock facies (Fumarolic Unit), partly buried by flat-surfaced, olive-grey, pyroclastic density current deposit sequence (foreground). Post-depositional erosion channel on right. 8 March 1999 (photo B.V.)

and abrupt frontal snouts c. 20-40 $\mathrm{m}$ in height. Stoppage of the first prominent lobe, near the east channel margin, apparently was caused by the flow running up against a bedrock ridge exposed within the channel (Fig. 18; see General description section). This was followed soon after by a pile-up of successive flow fronts against the first. Each lobe contained the same stack of Chartreuse and Soufriere Subunits, with green-orange-white deposit types (Fig. 21a). The disposition of deposits suggested that the main current of avalanche debris in the central channel continued in motion while the eastern lobe fronts came lo rest (Figs 1 and 18). As this main current thinned and velocity waned, the larger blocks tended to become grounded, and the resulting large-block-depleted residual flow spread out to produce a broad, sheet-like deposit at the avalanche terminus, with sparse hummocks as much as a few metres high.

In the distal region, parts of the avalanche deposit displayed numerous structures and diverse textures resulting from compressional, extensional and shear deformation of the avalanche as it moved and deposited (Figs 21 and 24). Megablock facies materials 

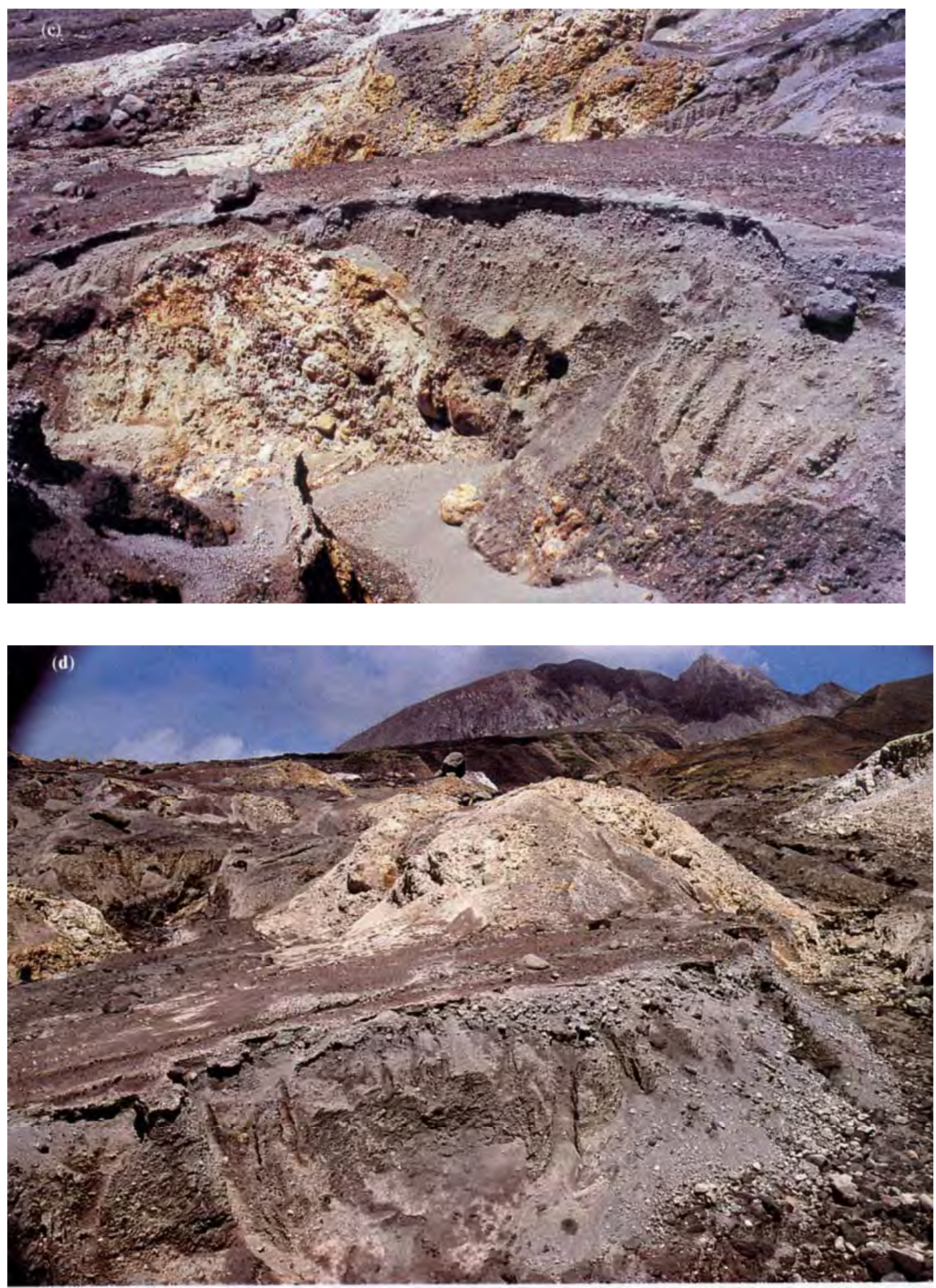

Fig. 21. (continued)

were compressed in areas where avalanche material flowed around, or rode up against, previously deposited hummocks. In a few such places, compression led to thrust-sheet slacking of displaced stratigraphic units.

Shear features include deformation of weak megablock facies domains into elongated slivers that surround more coherent malerial (Fig. 24c), alignment of such slivers, and stretched blocks of megablock facies carried within avalanche matrix facies. In the basal parts of the steep flow fronts at the distal eastern margin, and also at the head of the Fergus Mountain narrows, elongated, flattened megablock facies slivers suggest that the lithological units were squeezed and sheared under the moving overlying avalanche pile (Fig. 24d). Such shear textures reflected localized velocity gradients in the flow, and were consistent with frictional energy dissipation mainly at and near the avalanche boundary surfaces.

Textures produced by extensional deformation within the avalanche included the formation of fractures with jigsaw-fit (Glicken 1986. 1998; Ui 1983; Ui \& Glicken 1986). Such cracks became more abundant, and with larger gaps, with increased distance from the avalanche source. The avalanche thus became increasingly fragmented, by greater separations of jigsaw-fit fractures, to produce a population of small clasts that themselves could fragment, by jigsaw-cracking, into smaller clasts. This process has been shown elsewhere to occur on all scales (Komorowski et al. 1991).

Finally, clastic dykes several metres across, of dome-lavaderived debris that intruded megablock lacies maierial, occurred 

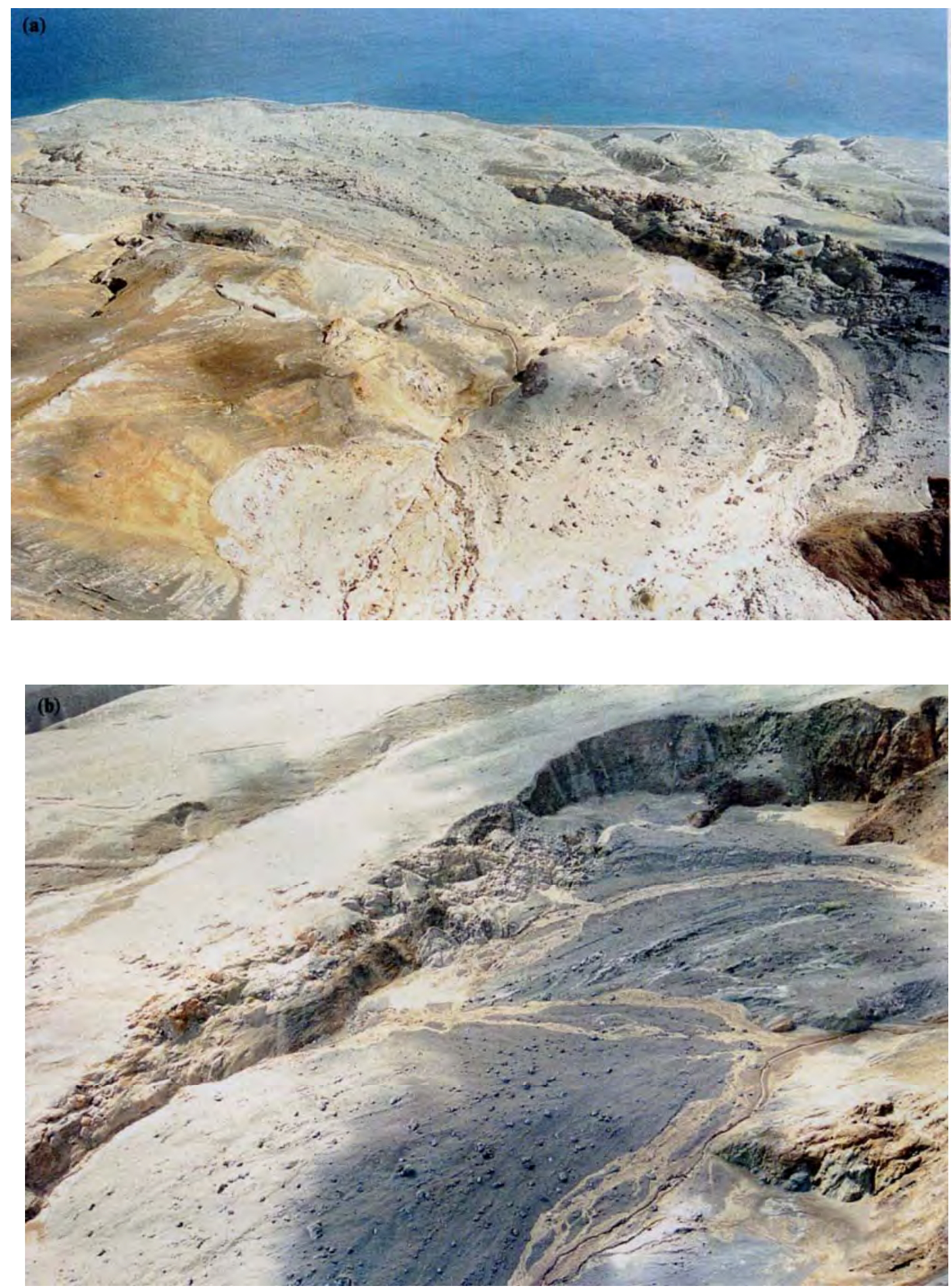

Fig. 22. Overspill areas, medial region, (a) Sweeping view to south of White River valley from above upper bend at Fergus Mountain, June 1998. Avalanche ramped over west bank, toward Morris', and formed levee-like deposit over inside bend of east bank. Hummocky distal deposit at upper left shows frontal avalanche lobes. Valley centre filled by coarse pyroclaslic density current deposits, and post-Boxing Day block-and-ash flow and lahar deposits. Pyroclastic density current deposits include arcuate deposit inside bend at lower left, and table-shaped overspill pyroclastic deposit in left-centre (photo J.C.K..). (b) Overspill areas viewed toward west in June 1998, showing complex pile-up of avalanche debris against and over the west channel bank (photo J.C.K.). Avalanche deposits on Fergus Mountain flank at lower right (for detailed view, see Fig. 20c). (c) Detail al east edge of Fergus Mountain overspill, January 1998 (photo B.V.). View to west. Sheared Soufriere Subunit pyroclastic sequence on left, talus unit on right. Near sample location 15-2 (Fig. 23). (d) View of Morris' overbank deposit, 8 July 1998, showing prominent hummocky flow front 20-40 m high (photo MVO). Ground surface in front of avalanche was scoured by the subsequent pyroclastic density current (grey deposits) and was veneered by a tar-like coating. A second flow front in the avalanche deposit is in sunlight a few hundred metres behind first flow front.

locally throughout the avalanche deposit. In the proximal region, dykes of dome-lava clasts intruded from below into megablocks of Charteuse Subunit materials (Fig. 24b). The lava clasls may have been derived from November 1997 block-and-ash flow deposits that capped the valley-fill sequence before Boxing Day. In the overspill location near Morris', rapid flow of the avalanche over the high valley walls probably induced marked local dilatation and fracture of cohesive megablock facies, promoting the infilling. Evidence at some locations, such as near Figure 20d, revealed that some cracks were filled from above with Talus Unit debris. Such dykes could have resulted from avalanche flow over the relatively rough topography of the valley floor, causing cracks to open in stretched 

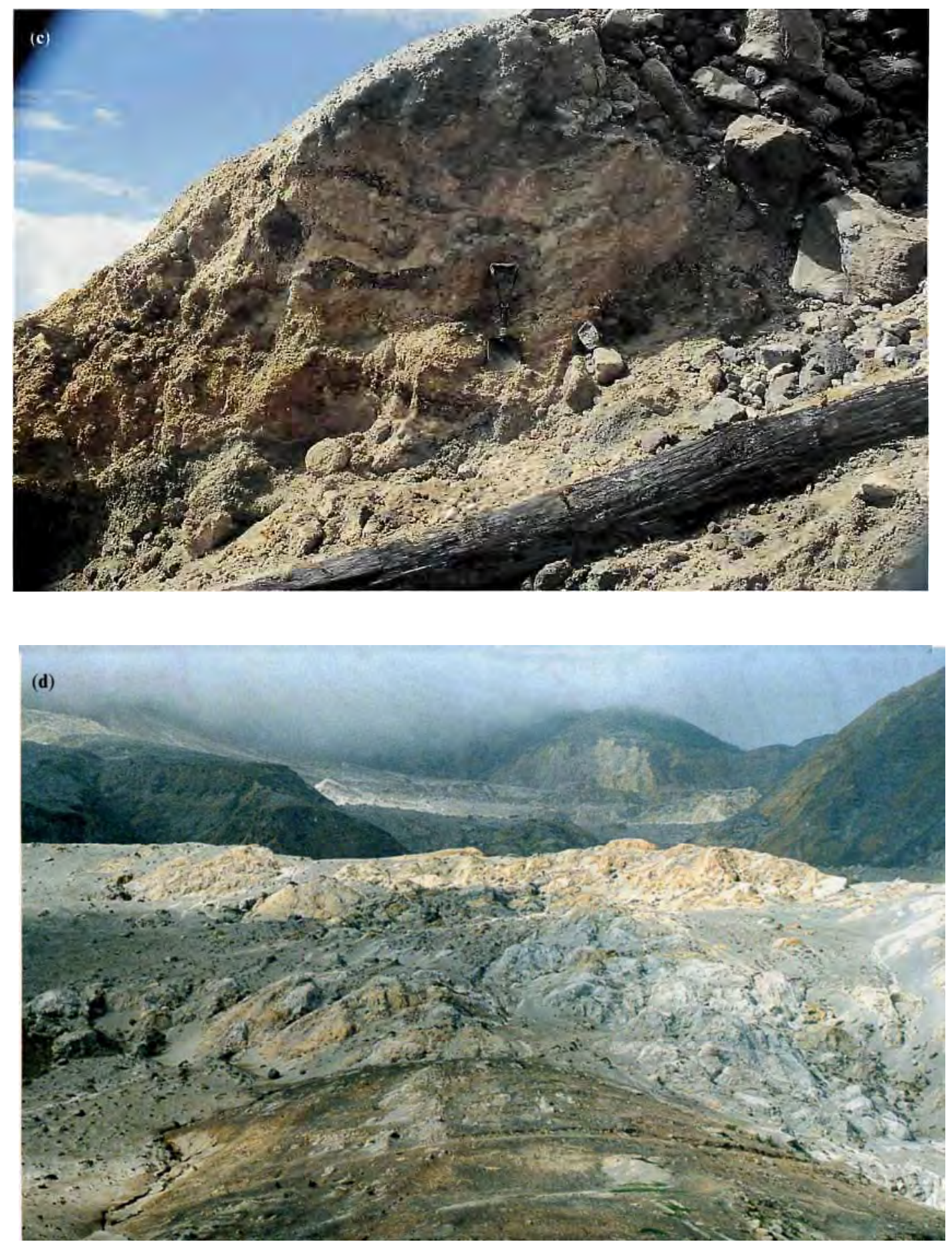

Fig. 22. (continued)

avalanche megablock facies debris. The cracks were then filled by cohesionless lava particles, caving downwards under the influence of gravity and facilitated by jostling.

\section{Mutual relationships between pyroclastic current and debris avalanche deposit}

The sector collapse was immediately followed by a high-energy pyroclastic density current (Sparks et al. 2002). Several depositional facies were associated with this pyroclastic current (Ritchie et al. 2002), and the general area of the White River valley and adjacent areas near St Patrick's and on the flank of Fergus Mountain were dominated by erosional features related to its passage (Figs 14 and
15). The debris avalanche deposit surface was scoured and striated. The debris avalanche was not generally hot. Its debris lay directly on top of the old vegetation and soil sequence, and buried leaves were unburnt. However, because it was scoured by the hot turbulent pyroclastic density current, wood that protruded from the avalanche deposit was charred. A black tar veneer several millimetres thick covered much of the landscape not buried by the avalanche deposit in the vicinity of the White River, and resulted from the nearly instantaneous distillation of the vegetation and organic soil by the hot current (Figs 14 and 22d). A second, highly energetic pulse of the pyroclastic current then passed abrasively over the tar and shaved-off the trunks of trees (Sparks et al. 2002).

The tar was absent beneath the debris avalanche deposit where it was excavated in a number of distal locations near Morris' 


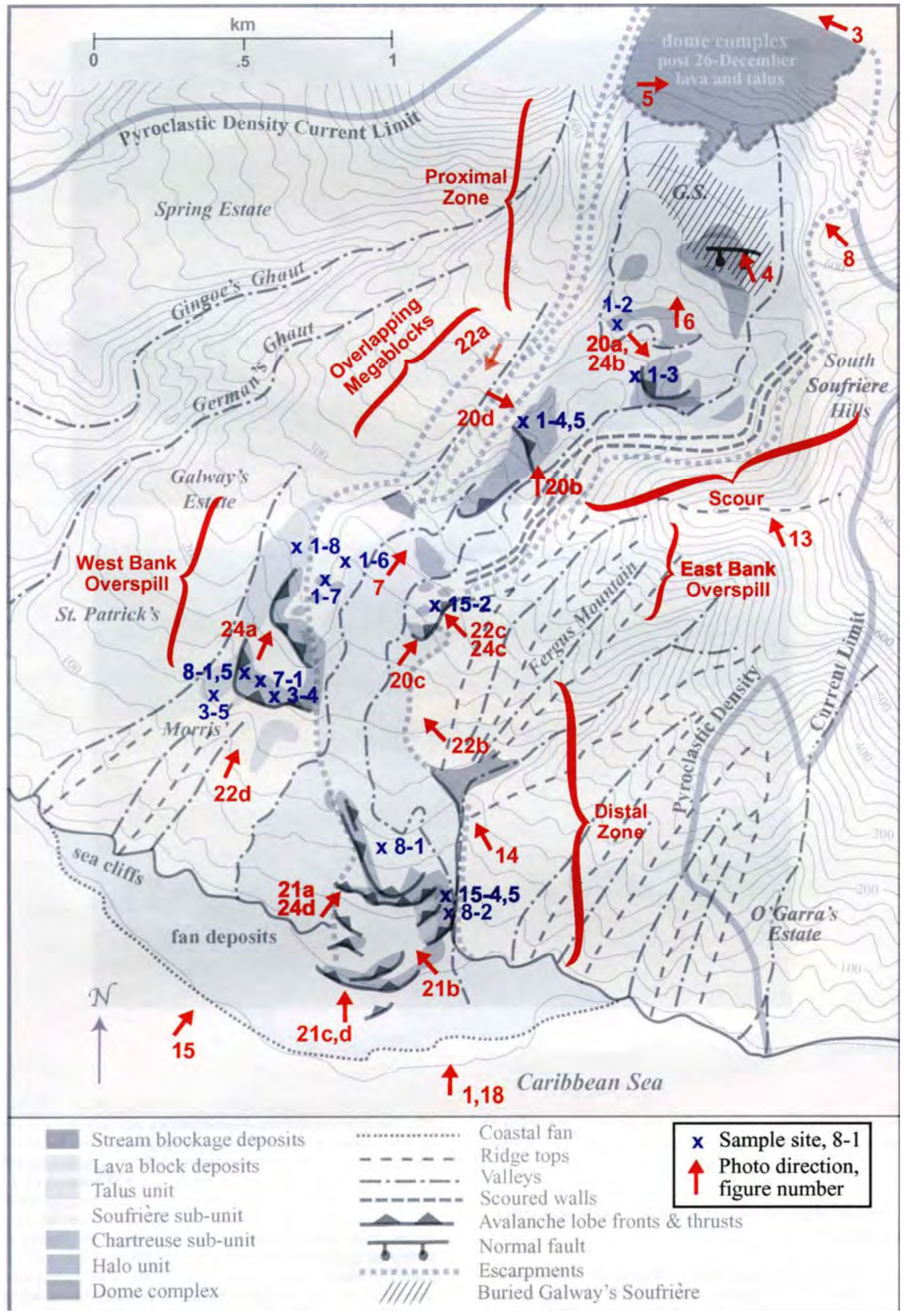

Fig. 23. Sample locations of debris avalanche deposits and associated pyroclastic deposits. Photograph views denoted by arrows and figure number. Base map from Figure 19. 

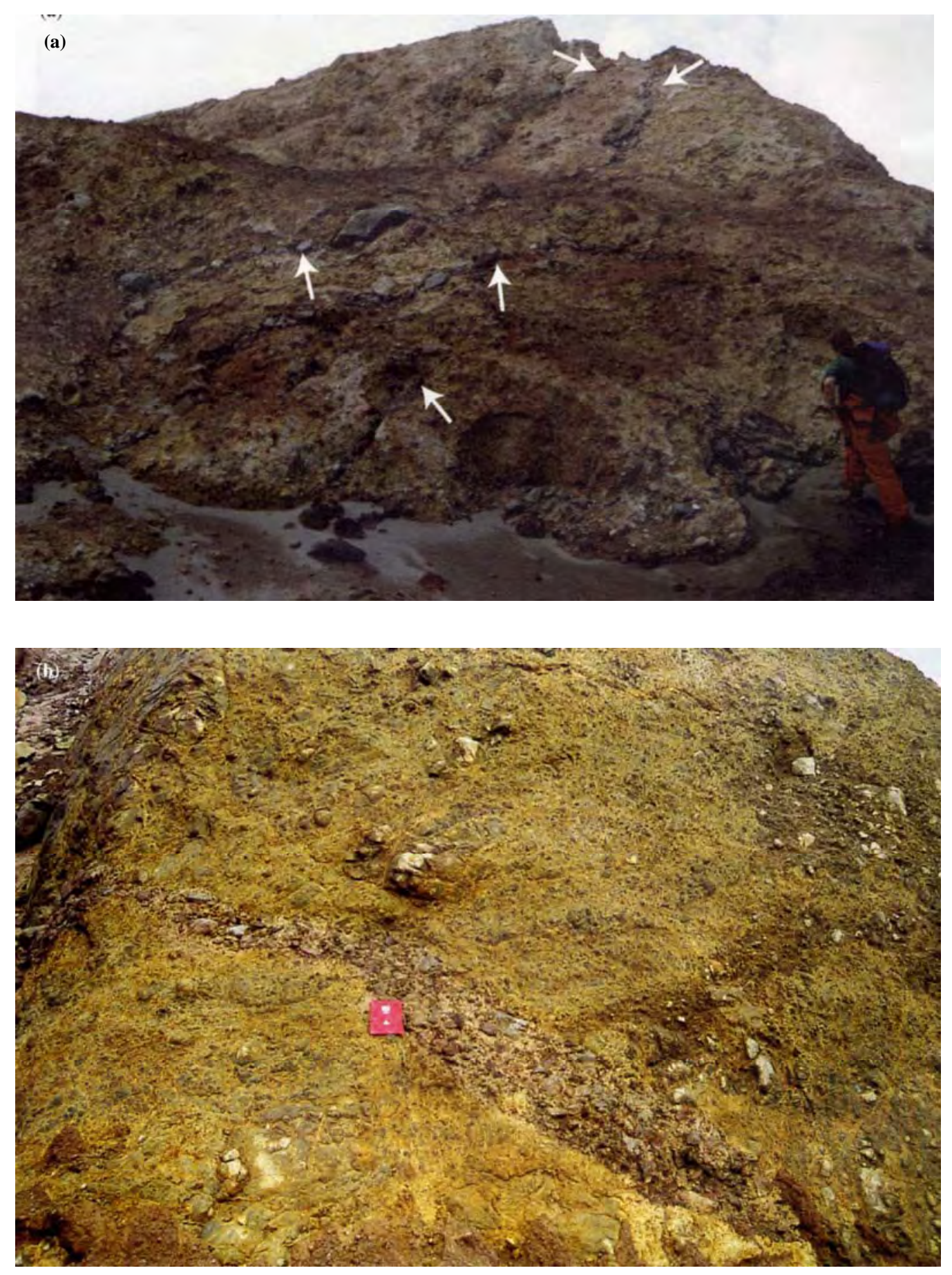

Fig. 24. Deformation structures in avalanche deposit (photos J.C.K.). (a) Dome lava clasts intruded as elastic dykes (arrows) into massive Soufriere Subunit materials in the Morris' overspill deposit, upper lobe, in June 1998. (b) Clastic dykes of dome lava clasts intruded into Chartreuse Subunit materials, probable toreva block, east side of proximal region of avalanche deposit in June I998. Lava clasts were probably derived from November 1997 block-and-ash flow deposits forming the valley surface material before the sector collapse. (c) Shearing of soft avalanche blocks into elongate slivers that enclose more rigid blocks. Distal region in June 1998. (d) Flattened, sheared block texture in avalanche deposit in distal region in March 1999. Shearing prominent near basal part of $20 \mathrm{~m}$ flow front. Charcreuse Subunil overlain in sharp contact by Soufriere Subunit, with dome lava Talus Unit on top.

(Fig. 22d), which showed that the debris avalanche had deposited here before the hot density current reached the lower slopes. The evidence for relative timing of these events is not definitive in the main channel, south of the Morris' overspill. In some other cases, pyroclastic currents overtook the debris avalanche while the latter was still in motion, e.g. Mount St Helens (Voighl et al., 1981; Glicken 1986, 1998) and the Taapaca avalanche, Chile (J. Clavero \& R. S. J. Sparks, unpublished data).

Several post-avalanche-emplacement pyroclastic flow deposits occurred. As well as those associated with the Boxing Day collapse, deposits of later pyroclastic flows and lahars have infilled some areas, burying debris avalanche and pyroclastic deposits in the White River valley (Fig. 22a, b). A fines-poor, coarse (clasts to $3 \mathrm{~m}$ ) unconsolidated pyroclastic breccia was deposited from the Boxing Day density current as sheets and patches overlying the avalanche deposit. These were lithologically similar to dome lava talus that comprised part of the avalanche deposit. The two deposit types, in principle, might be distinguished on the basis of texture (generally less matrix in talus), energy of emplacement (highest for the pyroclastic density current) or temperature (cooler in talus). In places 

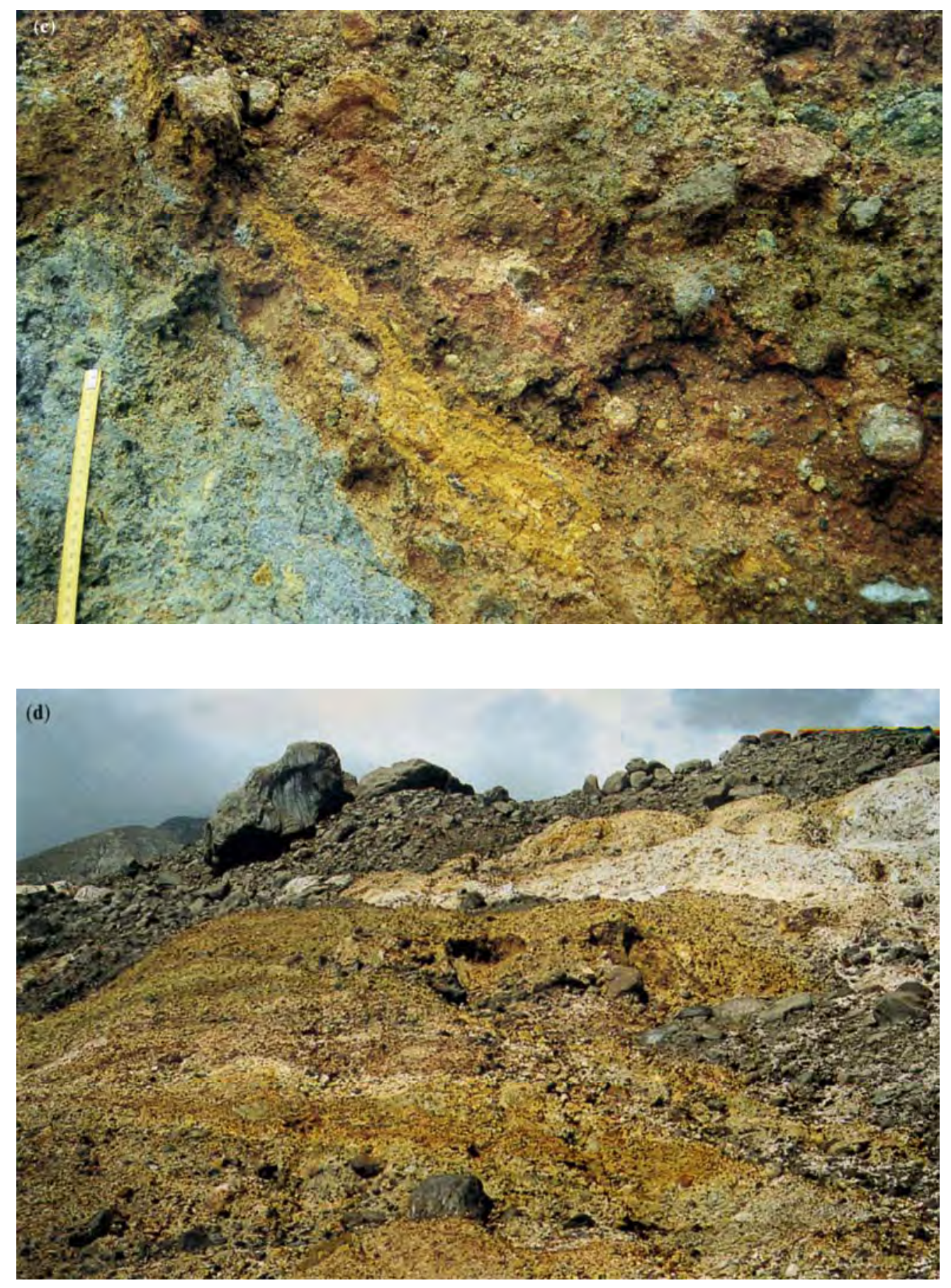

Fig. 24. (continued)

the deposits could be traced into unambiguous pyroclastic current deposits away from the avalanche deposits. In some locations the blocky flows rode up or beyond the walls of the White River valley, resulting in coarse breccia deposits plastered against valley walls or on overbank benches, with a striking streamlined morphology in profile and plan (Figs 14 and 22a; cf. Ritchie et al. 2002).

Within the hummocky area of the distal avalanche deposit, massive pyroclastic deposits with a repetitive two-layer stratigraphy occurred. These draped over eroded hummocks and were ponded between them (Fig. 21c.d). A wavy-bedded and finely laminated. moderately sorted, fine-grained facies formed the upper layer, overlying a coarser, fines-depleted layer. These two layers were most prominent on top of hummocks and adjacent ridges, although either could occur separately and both had been eroded by subsequent events. The inter-hummock ponded deposits showed extreme lateral textural and depositional variations, and lacked well developed laminae unless there was $>5 \mathrm{~m}$ distance between hummocks. In some places there were two coarse, poorly sorted massive layers, with a greenish lower layer, commonly inversely graded, rich in charcoal and containing yellow and orange hydrothermal chunks torn from the debris avalanche deposit, overlain by another massive layer rich in dome lava clasts with a pinkish, finer sandy matrix, and with prominent degassing pipes. Locally, a well sorted compact pinkish sandy deposit was found between two sets of the massive, poorly sorted layers containing clasts from the avalanche. On ridges only affected by the pyroclastic density current, and in some areas on the outer edge of the avalanche deposit, this well sorted deposit overlay a surface of striated tar. Calder et al. (1998) interpreted this well sorted deposit as the result of a surge-derived pyroclastic flow formed by 


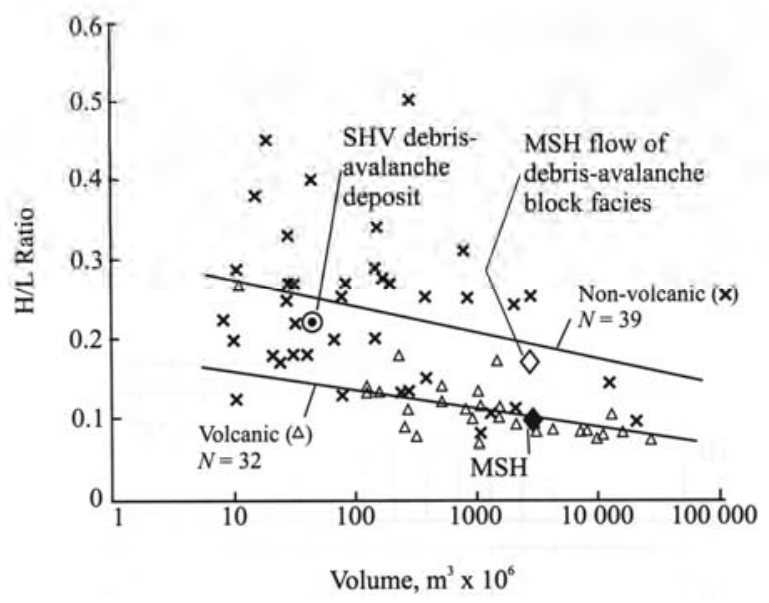

Fig. 25. Ratio of vertical fall height $(H)$ to horizontal runout distance $(L)$ versus volume for volcanic (triangles) and non-volcanic (crosses) debris avalanches, with regression lines after Voight et al. (1985). Boxing Day avalanche (SHV) compared with Mount St Helens (MSH) avalanche I (block facies, open diamond), and entire avalanche (black diamond), based on Glicken (1986, 1998)

sedimentation from the low-concentration part of the pyroclastic density current (cf. Druitt et al. 2002). Deposition on sloping hummock flanks resulted in flows draining onto the ponded facies, thus creating complex spatial and temporal relationships although all events occurred within a brief timeframe. The ponded pyroclastic deposits still had a temperature of $57^{\circ} \mathrm{C}$ at about $40 \mathrm{~cm}$ depth in March 1999.

\section{Dynamical constraints on avalanche emplacement}

A possible indicator on debris avalanche dynamics was the emplacement of deposits on the sides of the White River valley near the Fergus Mountain narrows. Simplistically, from conversion of kinetic energy to potential energy and neglecting friction, the deposit at Morris', and elevations 200- $220 \mathrm{~m}$ and $60 \mathrm{~m}$ above the surface of the channelled avalanche deposit, suggests a minimum flow velocity of $35 \mathrm{~ms}^{-1}$. The overspill may have been partly influenced by the rise of the peak avalanche flow wave through the constriction at the Fergus Mountain narrows. If so, the minimum velocity inferred by calculation is to some extent reduced.

A reliable but limited constraint on avalanche dynamics was offered by the destruction of the MSPT seismic station at St Patrick's by the pyroclastic density current (Fig. 2a), at 03:03.3 LT (Sparks et al. 2002). The initial collapse began at 03:01.0. Since the over-spilled part of the avalanche had stopped when overrun by the hot density current near Morris' (Figs 14 and 22d), the avalanche runout off c. $2.6 \mathrm{~km}$ (measured from the toe of the slide scar, to Morris') occurred within 138s indicating a minimum average velocity of $19 \mathrm{~ms}^{-1}$. If the full channelled avalanche runout of c. $3.7 \mathrm{~km}$ also occurred within this period, a possibility not excluded by the evidence, then the minimum average velocity was $27 \mathrm{~ms}^{-1}$.

The mobility of volcanic debris avalanches can be empirically characterized by the ratio of maximum vertical fall height $(H)$ to overall travel distance $(L)$, in this case as measured from the rear scarp of the original slide mass to the snout of the deposit (Ui 1983; Voight et al, 1983, 1985; Sicbert 1996). Using simplified models, this ratio can be cautiously interpreted in terms of the apparent coefficient of friction of the avalanche (Pariseau \& Voight 1979). The highest part of the Boxing Day debris avalanche fell from a maximum height of about $1000 \mathrm{~m}$ (near the summit of the dome), and its travel distance $L$ as defined above was about $4500 \mathrm{~m}$ suggesting $H / L=0.22$. By comparison, at Mount St Helens the debris avalanche 1 (avalanche megablock facies) was characterized by $H / L=0.17$, and the full Mount St Helens avalanche had $H / L=0.09$ (Sousa \& Voight 1995). H/L ratios have been observed to be volume-dependent (Fig. 25), with the observed $H / L$ ratios ranging from 0.09 to 0.18 (average 0.13 ) for Quaternary volcanic debris avalanches between 0.1 and $1 \mathrm{~km}^{3}$ in volume, and from 0.04 to 0.13 (average 0.09) for avalanches $>1 \mathrm{~km}^{3}$ (Voight et al. 1985; Siebert 1996). Thus, from this simple measure, the Boxing Day debris avalanche had low mobility compared to those reported for large volcanic debris avalanches elsewhere (Fig. 25). This result is consistent with the relatively small volume of this deposit in comparison to, say, the Mount Si Helens debris avalanche, and the tortuosity of the channel. Numerical modelling of the emplacement dynamics is considered below.

\section{Physical properties}

\section{Avalanche deposit materials}

Granulometry. The avalanche deposit was extensive and the material heterogeneous, varying from clay particles to megablocks $>100$ $\mathrm{m}$ wide. Representative sampling was impossible for much of this material, but we attempted to characterize it at least in broad terms. Because the avalanche deposit contained boulder-sized clasts unsampled for sieve analyses, the actual sorting of the deposits is commonly poorer, and the median diameters larger, than indicated by our data. Most samples represented avalanche megablock facies or non-cohesive facies materials, in large part derived from source clastic rock of the failed edifice, or unconsolidated talus deposits. The grain-size characteristics observed were largely influenced by the source materials and the textural modifications that occurred as a result of sector collapse and debris avalanche motion.

Grain-size distributions were determined on samples (several kilograms) from diverse localities on the avalanche deposit (Fig. 23). Most samples were subjected to standard dry-sieve analyses, with sieves from 5 to -6 phi. When appropriate, optical scanning of aqueous dispersions (the 'microtrac' method) was used to ascertain grain sizes of the fine fraction, to 9 phi. Most samples were gravelly sand or sandy gravel, with up to $15 \%$ silt and clay grade particles (Fig. 26). Typical values were about $6-15 \mathrm{wt} \%$ for combined clay $(<0.004 \mathrm{~mm})$ and silt, 30-53 wt\% sand, and 33-62 wt\% for the $>2 \mathrm{~mm}$ fraction of pebbles, cobbles and organic debris.

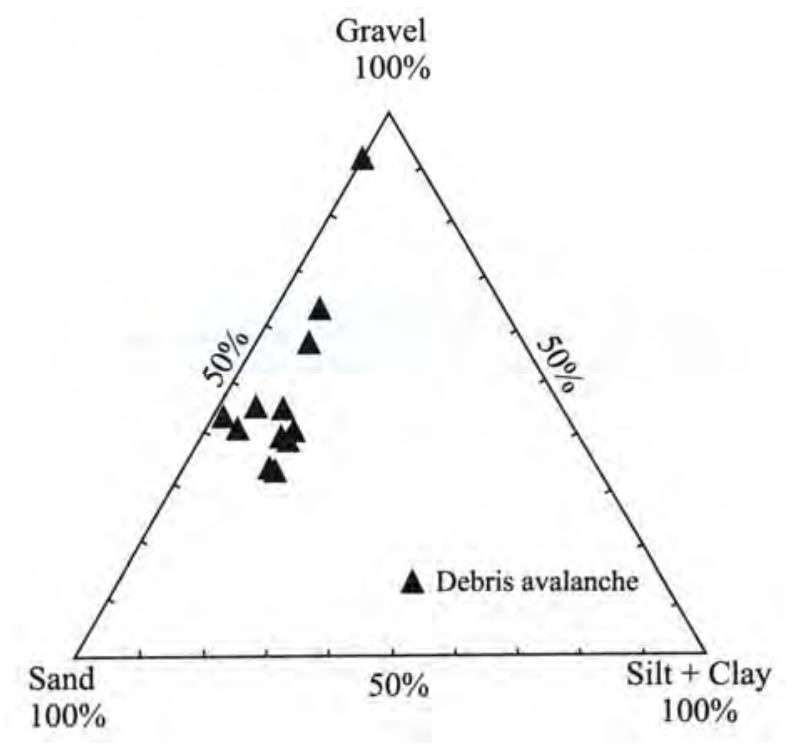

Fig. 26. Percentage of gravel $(>2 \mathrm{~mm})$, sand $(2-0.063 \mathrm{~mm})$, and sill + clay $(<0.063 \mathrm{~mm})$ in samples of the debris avalanche deposit. 


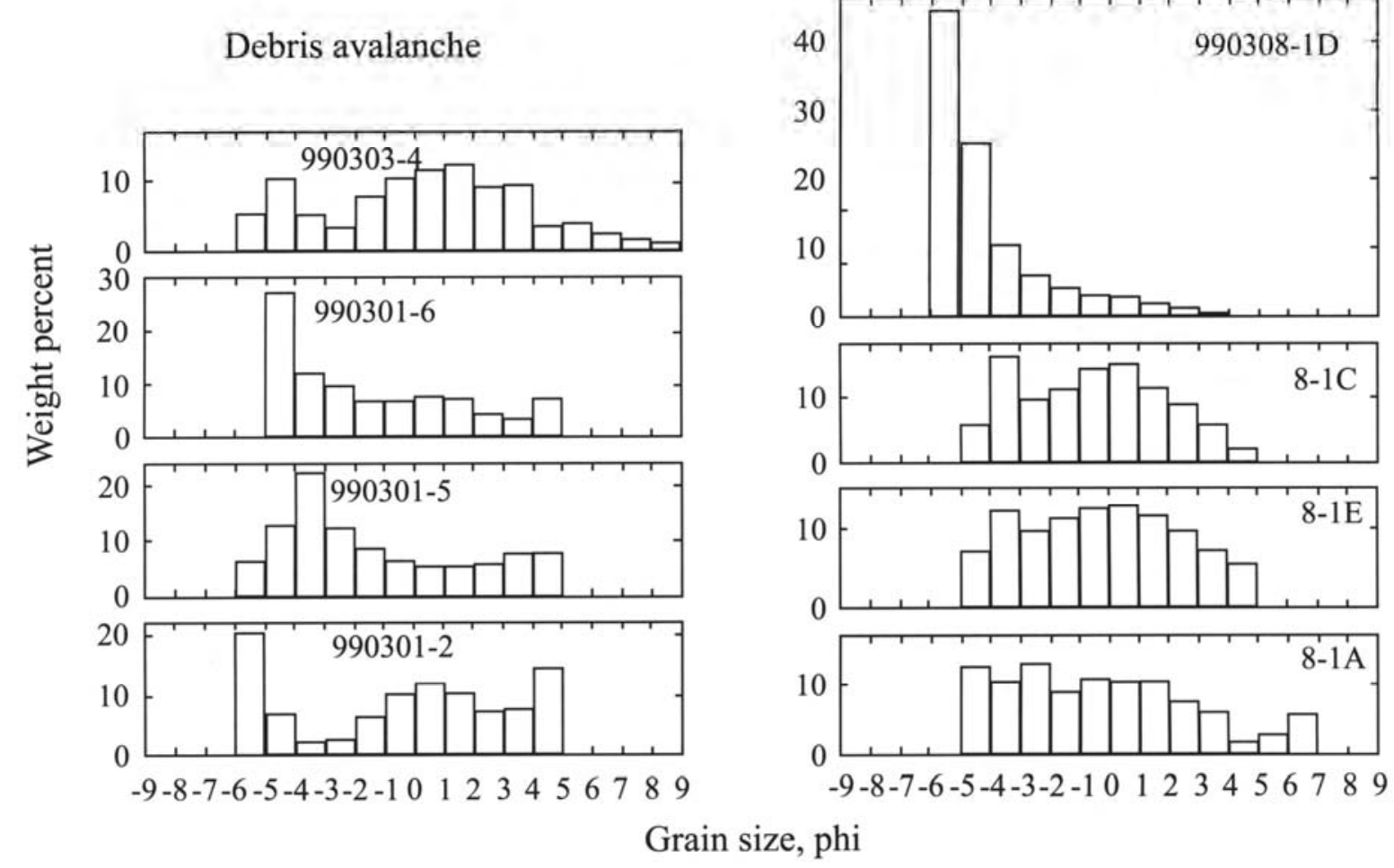

Fig. 27. Typical grain-size histograms of debris avalanche. Sample locations shown in Figure 23.

Histograms of grain-size distributions of the deposits had several distinctive characteristics (Fig. 27). In some cases the coarsest fractions (<-6 phi) were absent (as reflected by truncated histograms at coarse modes), but field observations indicated that in most cases this was the result of incomplete sampling owing to the limited sample size. The histograms were mostly polymodal. Modes around 0 to 1 phi and less than -3 phi were relatively common, and minima around -1 to -3 phi occurred in many samples. A frequency minimum between -1 and -2 phi occurred in samples of megablock facies material at Mount St Helens, Augustine and Shiveluch volcanoes (Glicken 1998; Siebert et al. 1995; Belousov et al, 1999), but such a tendency was undeveloped or only weakly developed in our samples.

Such diffuse polymodal grain-size distributions constituted poor sorting and a wide range of median diameters. Median grain size typically varied from 0.6 to 2.9 phi, and exceptionally to -4.8 phi (sample 308-1d). Sorting coefficients (Inman 1952) ranged from 1.7 to 4.5. On a plot of median diameter versus sorting (Fig. 28), most samples fell into the coarse-grained part of the axial zone of the pyroclastic flow field of Walker (1971), suggesting these debris avalanche deposit samples had textures similar to pyroclastic flow deposits. Probably this correlation reflects the fact that much of the avalanche source material was derived from ancient pyroclastic flow deposits. Towards both the largest and the smallest median diameters, some improvement in sorting was observed.

Within the White River valley, the sorting coefficients and median diameters maintained roughly similar values from the source to the distal end (Fig. 29). The biggest differences occurred as a result of source-rock lithological variation, with the most extreme values in fines-depleted coarse materials at one end of the spectrum, and clay layers or lenses on the other end, representing local clay-rich alteration products in Soufriere Subunit material. These variations were present at distances $>3 \mathrm{~km}$ from the crater, reflecting mainly the wider range of materials sampled and transported to the distal region.
Geotechnical tests. For some samples, a range of geotechnical tests was carried out. The most detailed tests were conducted on samples at location 15-2, representing overspill deposition on the west flank of Fergus Mountain (Fig. 23). The outcrop displayed Fumarotic Unit materials with sheared stratification. Sample 2A, taken as typical of the southern part of the outcrop, was mottled grey, brown and yellow clayey sand with gravel. Unified Soil Classification System (USCS) group SM, combined silt and clay content c 40wt\% (Fig. 30). (For a thorough account of these standard engineering descriptions and classifications of soils, see Bell 1993. Ch. 5.) Sample 2B was an overlying dark brown-grey silty sand (with gravel), USCS classification group SM, silt and clay

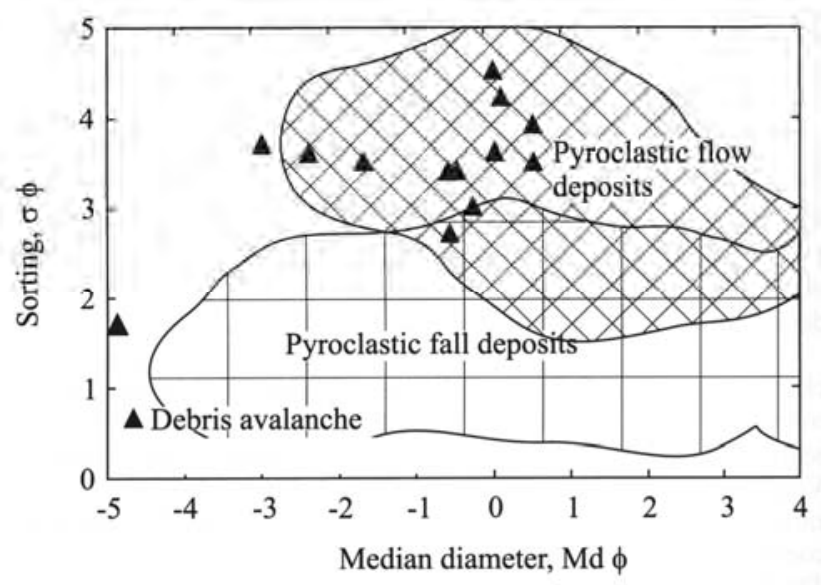

Fig. 28. Sorting and median diameter (Intnan coefficients) for the debris avalanche deposits. Cross-hatched field shows pyroclastie flow deposits after Walker (1971). 
(a)

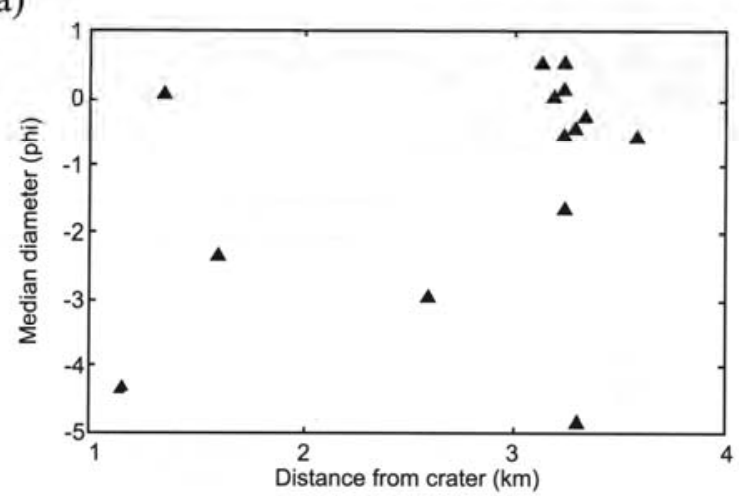

(c)

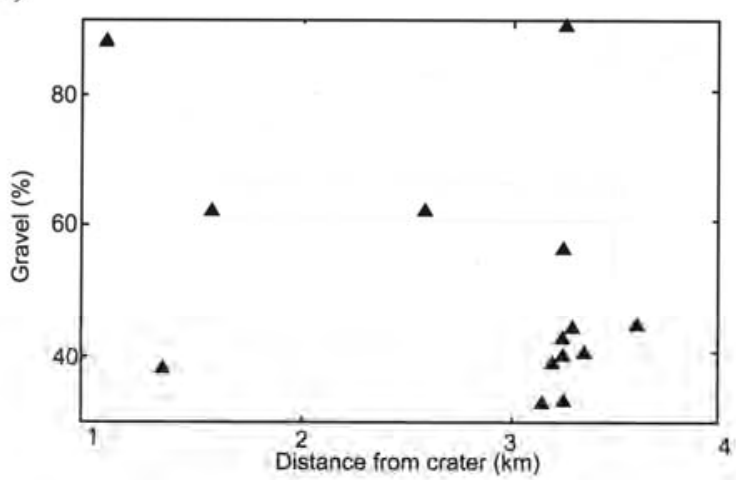

(e)

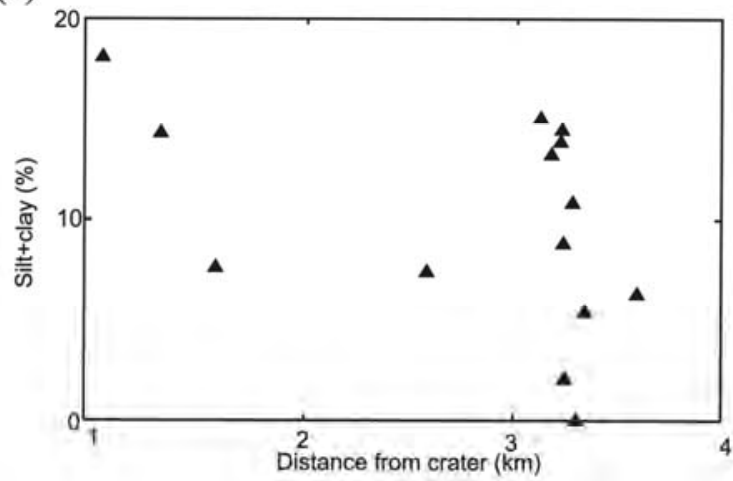

(b)

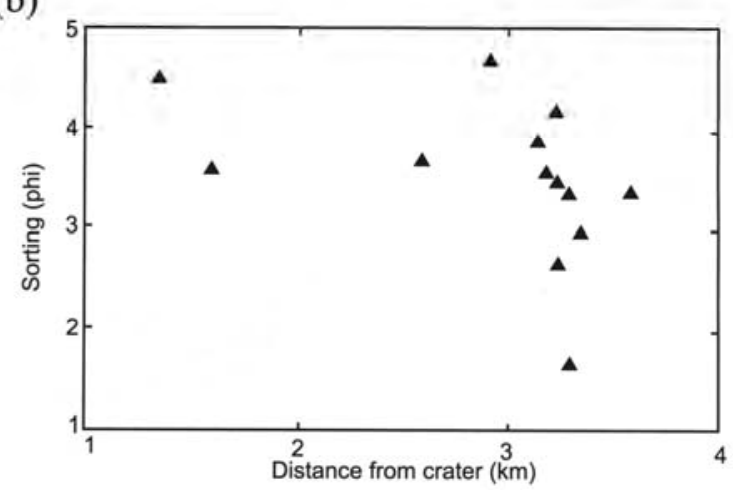

(d)

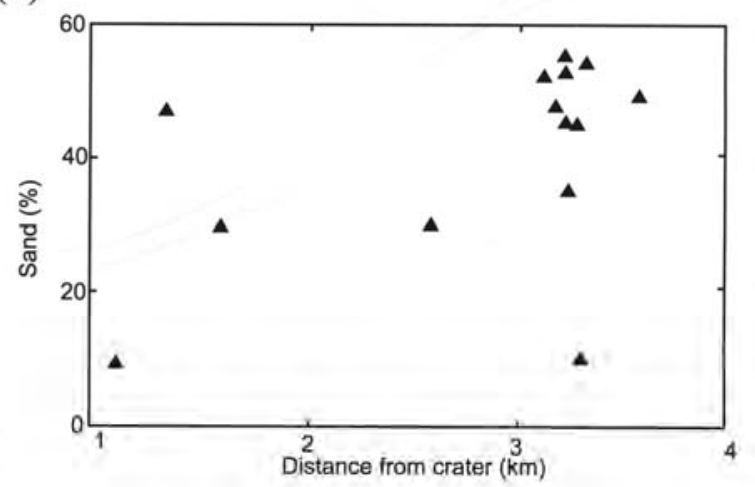

Fig. 29. Granulometric characteristics of block facies of debris avalanche deposit yersus distance from the volcano. (a) Median diameter. (b) Sorting. (c) Percentage gravel. (d) Percentage sand. (e) Percentage silt + clay, Granulometric definitions are given in caption of Figure 26.

content c. $31 \mathrm{wt} \%$. Sample 2C, representing a continuous layer in the outcrop, was an intact block of moist grey-brown plastic clay, USCS group $\mathrm{CH}$, silt and clay content c.96 wt\%. This clay block was cut out from the outcrop, wrapped in wet cloth, and transported to the laboratory in a sealed hard-plastic container.

Sample 2A was a shovel sample, and laboratory shear strength tests were conducted on representative split-screened portions of it using procedures described in the Appendix. The specimen was consolidated and sheared, and then repeatedly sheared to provide a measure of displacement-weakening. Curves of shear stress against cumulative horizontal shear displacement showed significant reduction in strength (Fig. 31). Shear stress versus normal stress plots indicated linear Coulomb effective-stress strength relations over the normal stress range examined (Fig. 32), with peak strength indicated by: cohesion $=57.5 \mathrm{kPa}$, peak friction angle $=25^{\circ}$. Resi- dual strength (large post-peak displacement) parameters were: cohesion $=33 \mathrm{kPa}$, residual friction angle $=17^{\circ}$. The term effective stress refers to the standard practice in geotechnical engineering of considering the differences between the total applied stresses and the pore fluid pressures (Lambe \& Whitman 1969).

Similar shear tests were carried out on clay-rich sample 15-2C, which showed contractive behaviour and profound reduction in strength (Fig. 31). Effective-stress strength relations were linear over the normal stress range examined (Fig. 32), with peak strength indicated by: cohesion $=77.8 \mathrm{kPa}$, peak friction angle $=13.5^{\circ}$. Residual strength parameters were: cohesion $=57.0 \mathrm{kPa}$, residual friction angle $=3.0^{\circ}$

These preliminary laboratory results indicate, to a reasonable approximation, the minimum frictional strength of Fumarolic Unit avalanche debris. The addition of coarse particles could increase 

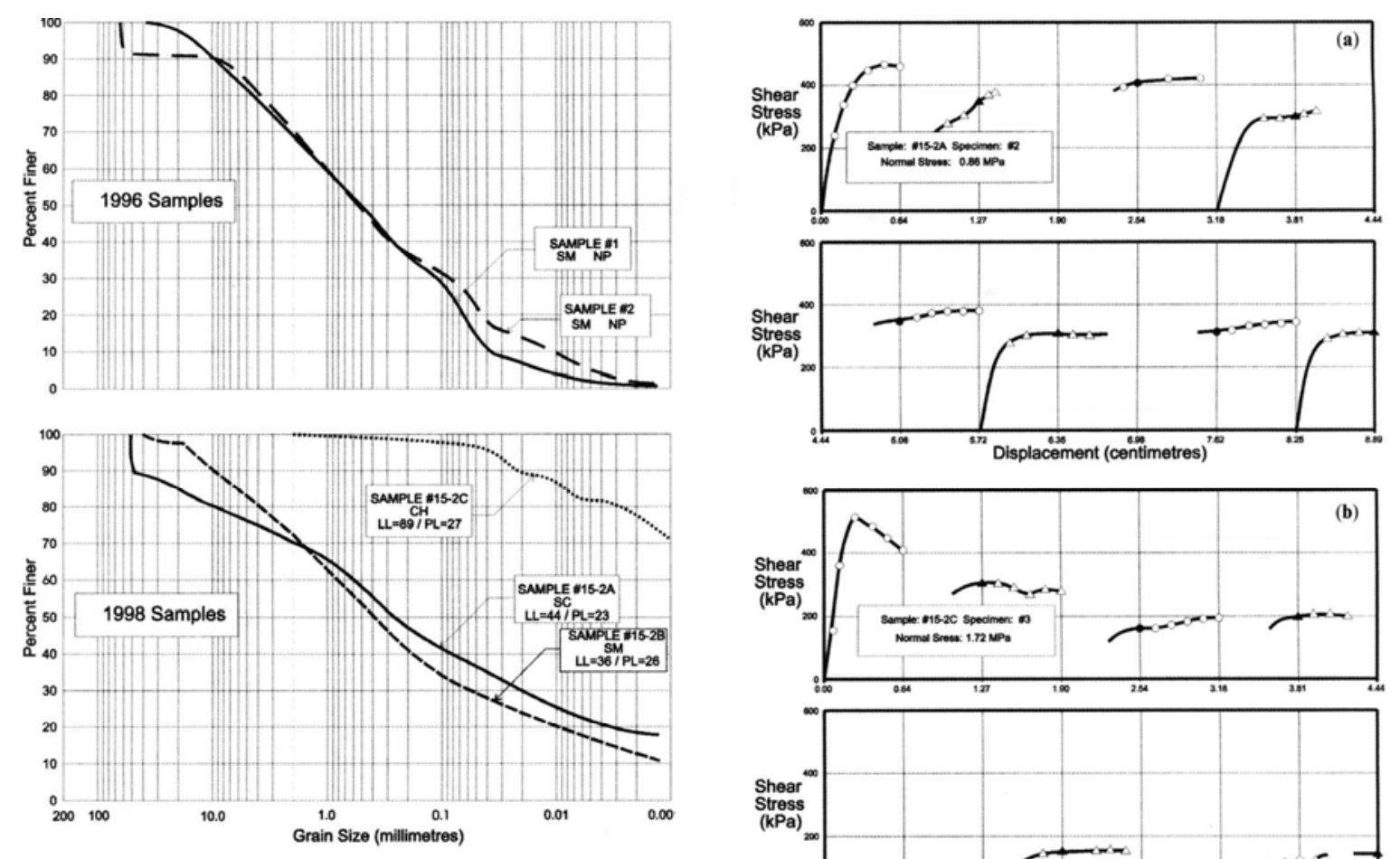

Fig. 30. Size-distribution curves for edifice (1996) and avalanche debris (1998) samples subjected to geotechnical testing.
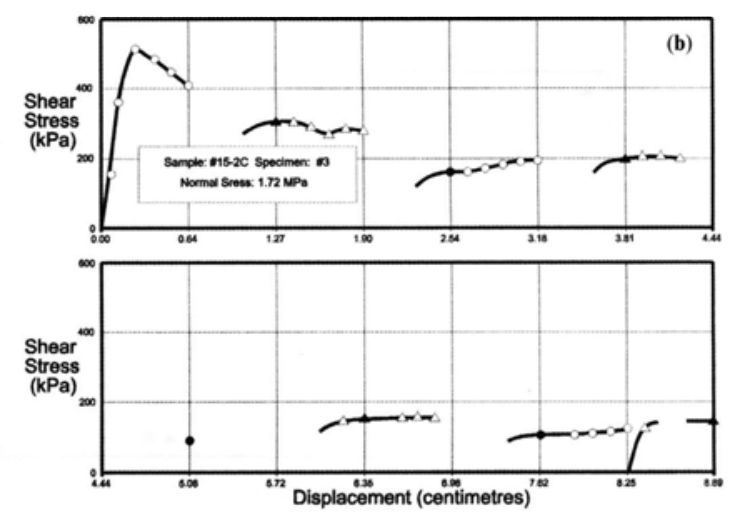

the strength above these matrix values, particularly for volumetric proportions $>25 \%$ (Medley 1997), although the reported values may be reasonable estimates of the local strength at avalanche or megablock boundaries. The values may also provide lower-bound strength estimates for full-scale slip-surface failure of Fumarolic Unit fragmental deposits during the Boxing Day sector collapse.

\section{Edifice materials}

Block samples of relatively weak intact tuff had been collected by B.V. and S.R.Y. at the base of Galway's Wall in March 1996, in anticipation of future instability (Voight 1996). Towards the end of 1996, the sampling site (near Fig. 5b) was buried by rockfall debris and dome talus (Fig. 6). Additional samples of weathered tuff were taken in March 1996 from the Gages Wall area of English's Crater (see Fig. 2), and samples of fresh (1995 lava) and altered (prehistoric lava) dome material were also acquired. In order to provide constraints for stability assessments, the block samples were subjected to laboratory triaxial rock-mechanics testing to provide the shear strength of intact material as a function of confining pressure, using procedures discussed in the Appendix. Additional testing was carried out to obtain intact tensile strengths and specimen dry bulk density. Note that strengths reported below are for intact materials, and values appropriate for the in situ jointed rock-mass would generally be less (Voight 2000).

In general, the experimental Mohr-circle data indicated curved strength envelopes as a function of confining pressure. For Galway's Wall tuff, with dry bulk density of $1980 \mathrm{kgm}^{-3}$ and tensile strength of 1.21 MPa, results are shown in Figure 33. The data gave good agreement with the Hoek \& Brown (1980) failure criterion that predicts a parabolic envelope for brittle rocks subjected to compressive stress conditions, and approximates classic Griffiths theory in the region of tensile effective normal stresses.

Fig. 31. Shear stress versus displacement for reversal direct-shear tests on Soufriere facies debris avalanche samples. Note strength loss with displacement, (a) Remoulded sample I5-2A, clayey sand with gravel, normal stress $0.86 \mathrm{MPa}$. (b) Block sample 15-2C, highly plastic inorganic day, normal stress $1.72 \mathrm{MPa}$.

Considering the full Galway's Wall dataset, the Coulomb parameters yielded a linear fit with cohesion $=2.19 \mathrm{MPa}$ and friction angle $=33.0^{\circ}$, although this set of parameters underestimated strength at intermediate confining pressures, and overestimated strength in the tensile region (see Voight 2000). A piece-wise linear fit can provide reasonable Coulomb parameter approximations for different ranges of normal stress. Thus, for confining pressures $>2.07$ $\mathrm{MPa}$, the parameters cohesion $=3.65 \mathrm{MPa}$ and friction angle $=$ $31^{\circ}$ provide an adequate fit.

The weathered Gages Wall tuff was less dense and weaker, with dry bulk density of $1840 \mathrm{kgm}^{-3}$ and tensile strength of $0.41 \mathrm{MPa}$. Coulomb parameters for moderate compressive confining pressures were, approximately, cohesion $=1.7 \mathrm{MPa}$, friction angle $=32^{\circ}$, although, as noted, the envelope was non-linear (Fig. 33). Corresponding data for fresh dome lava collected in the southwest moat inside English's Crater, and mildly altered lava from prehistoric dome-derived breccia exposed in Galway's Wall, were obtained. Approximate Coulomb friction angles are $5^{\circ}$ and $44^{\circ}$, respectively.

In addition, disaggregated materials were collected from weathered tuffs presumed to be representative of the outer-slope base of Galway's Wall, and also from weathered portions of Gages Wall (Fig. 1). Both materials were classified as grey-brown silty sand with gravel, USCS group SM (Fig. 30). Laboratory shear strength tests were conducted, using methods summarized in the Appendix. At all normal stresses, higher resistance was obtained on second-cycle shearing, probably reflecting enhanced interlocking and dilatation between sliding or rotating angular grains, whereas further displacements caused some reduction in strength (Fig. 34). Linear Coulomb 

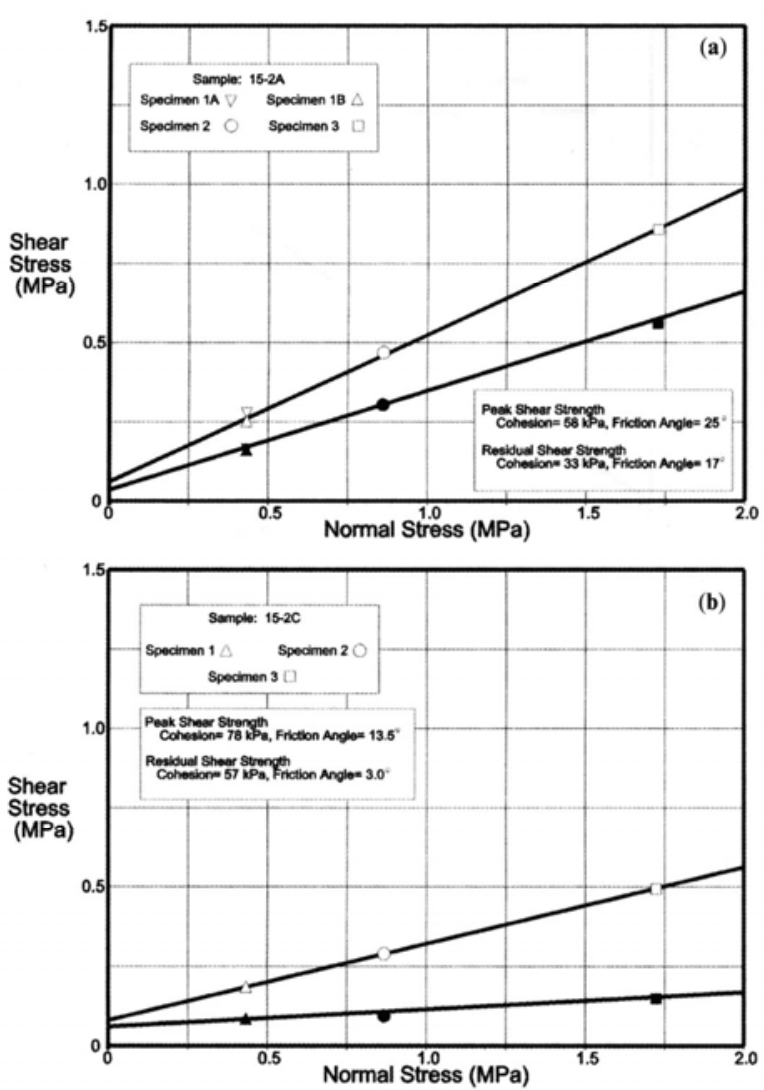

Fig. 32. Shear strength versus effective normal stress for Soufriere facies debris avalanche materials subjected to direct-shear tests, (a) Remoulded sample 15-2A, clayey sand with gravel, (b) Block sample 15-2C, highly plastic inorganic clay. Open symbols show peak shear strength; filled symbols show residual shear strength.

effective-stress strength relations applied approximately over the normal-stress range examined (Fig. 35). For both sites, a single nominal set of parameters seemed appropriate, namely zero cohesion, peak friction angle $=35^{\circ}$, residual friction angle $=31^{\circ}$. These parameters may he appropriate for disaggregated material, or blocks bounded by uncemented joints or joint gouge within the tested range of normal stresses.

\section{Stability assessments and failure mechanisms}

\section{Studies made before the sector collapse}

Growth of the andesitic lava dome at Soufriere Hills caused decreasing structural stability of the southern sector of the volcano. The possibility of a future instability problem in this sector was recognized in early 1996, and clear warning signs of growing instability were recognized in November-December 1996 (Young et al. 2002). Catastrophic sector collapse occurred a year later on 26 December 1997, during a period of enhanced seismicity and after two months of southward expansion of the lava dome and talus apron over the hydrothermally weakened area.

Preliminary quantitative stability assessments, using two-dimensional limiting-equilibrium analyses, were made during hazards evaluations at Soufriere Hills in March 1996 and December 1996 (B. Voight, unpublished data). In such analyses, a representative topographic profile and cross-section was drawn, to represent existing conditions and also some future conditions related to antici-
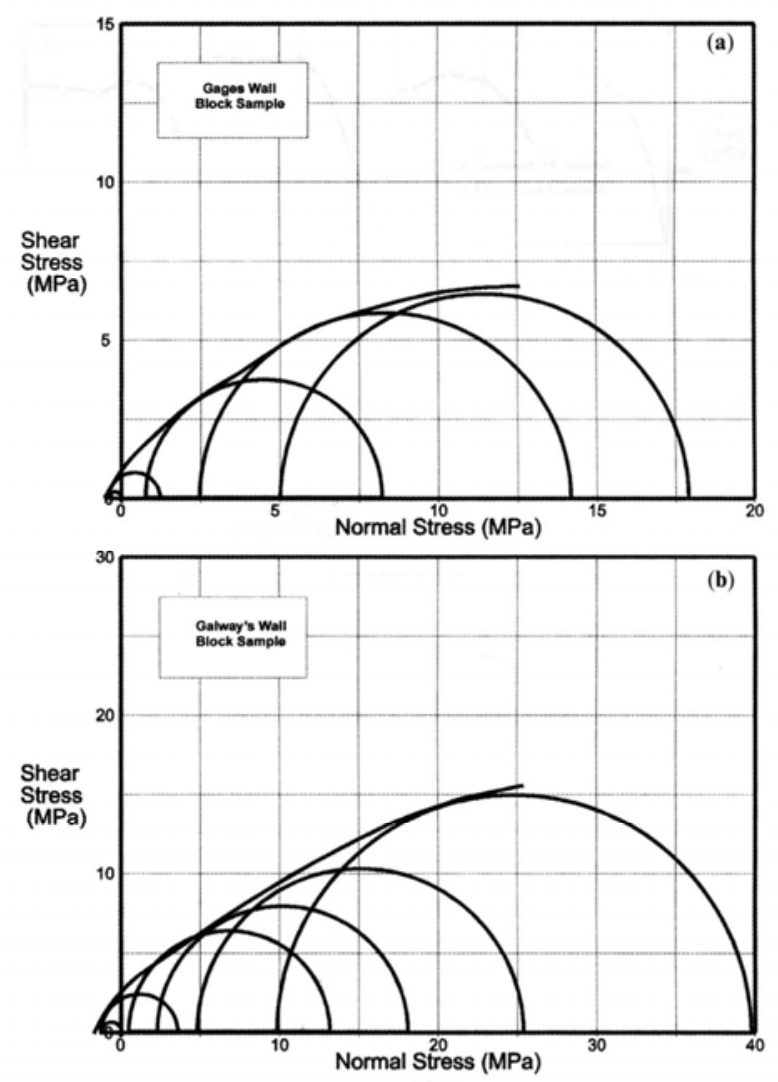

Fig. 33. Shear stress versus effective normal stress for intact samples of edifice materials subjected to triaxial and indirect-tension tests. Data plotted as Mohr circles, with curved envelope according to Hoek-Brown criterion, (a) Gages Wall tuff, altered, (b) Galway's Wall tuff

pated dome growth. A trial slip surface was postulated, and the shearing resistance required to equilibrate the mass of material on this surface (and other applied forces) was calculated by statics. The calculated resistance was compared with available shear strength to yield a factor of safety $F$, defined as the quotient of shear strength of the material and the shear stress required for static equilibrium. The value $F=1$ represents a condition of incipient failure, and $F>1$ represents stability. The procedure was repeated for other postulated slip surfaces, and the lowest $F$ was found by iteration (Duncan 1996; Voight 2000). Laboratory tests on block samples of indurated tuffs and dome rock, and samples of disaggregated materials, as described above, were used along with literature data to constrain the stability analyses (Voight 1996); scaled reductions were used for rock-mass properties (Hoek 1983; Voight 2000). Seismic loading was simulated simply by a coefficient that represented the potentially destabilizing earthquake force due to horizontal acceleration of the material (Kramer 1996).

The results of these stability analyses suggested that the outer part of Galway's Wall was marginally stable with respect to static loading for the dome geometry existing at that time. Stability decreased when pseudo-static earthquake loading was added, and for horizontal accelerations on the order of $0.1 \mathrm{~g}$, shear failure on the upper south face of Galway's Wall was predicted by the analyses. The failures predicted were shallow, not deep-seated. Successive slope failures triggered by successive earthquake shocks were predicted to reduce wall thickness by exterior slabbing, rather than by massive deep-seated failure. The results did not preclude the latter possibility, given the uncertainties involving the forces caused by a shallow intrusion (Young el al, 2002), potential 

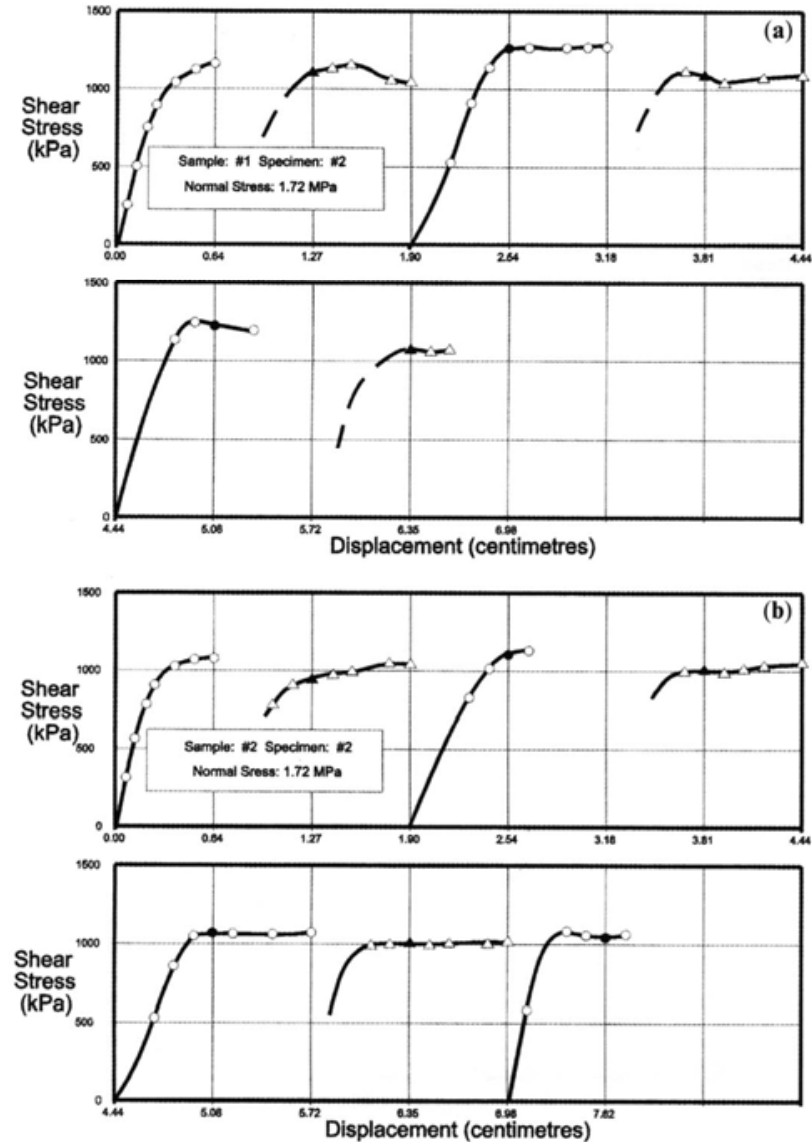

Fig. 34. Shear stress versus displacement for reversal direct-shear tests on disaggregated edifice tuffs. Note small strength loss with displacement. (a) Sample 1: Gages Wall tuff, altered. (b) Sample 2: Galway's Wall tuff.

through-going structural discontinuities within the wall, and assumed material properties. Indeed some radial cracks were observed and monitored (Young et al. 2002). However, it was recognized that deterioration of the wall by slabbing was most likely, and this could cause reduction of the wall height and consequently lead to overtopping by the growing dome, with rapid erosion of the friable, jointed wall rock. The deterioration of the wall in general followed the lines suggested by the analyses. Wall failures involved release of shallow slabs of jointed rock, triggered by the larger felt shocks in repetitive seismic swarms. Then, after several shifts in the locus of dome growth had reduced pressure against the south sector, lava overtopped the low point on Galway's Wall in March-April 1997, block-and-ash flows severely eroded parts of Galway's Wall, and Galway's Soufrière was partially buried by talus.

In addition to these analyses, axisymmetric finite element modelling was conducted to explore the stress changes associated with dome growth and conduit pressurization, for the geometry existing in late 1996 (Wadge et al. 1998). The analysis assumed homogeneous elastic media, and was somewhat limited inasmuch as pore pressures, seismic loading, material zonation, and plastic deformation were not treated. Relative stability was interpreted from the ratios of elastic-media shear stresses to an assumed Coulomb relation.

\section{Limiting-equilibrium analyses made in 1998}

Limiting-equilibrium stability analyses were carried out in January 1998, soon after the sector collapse, using the general procedures
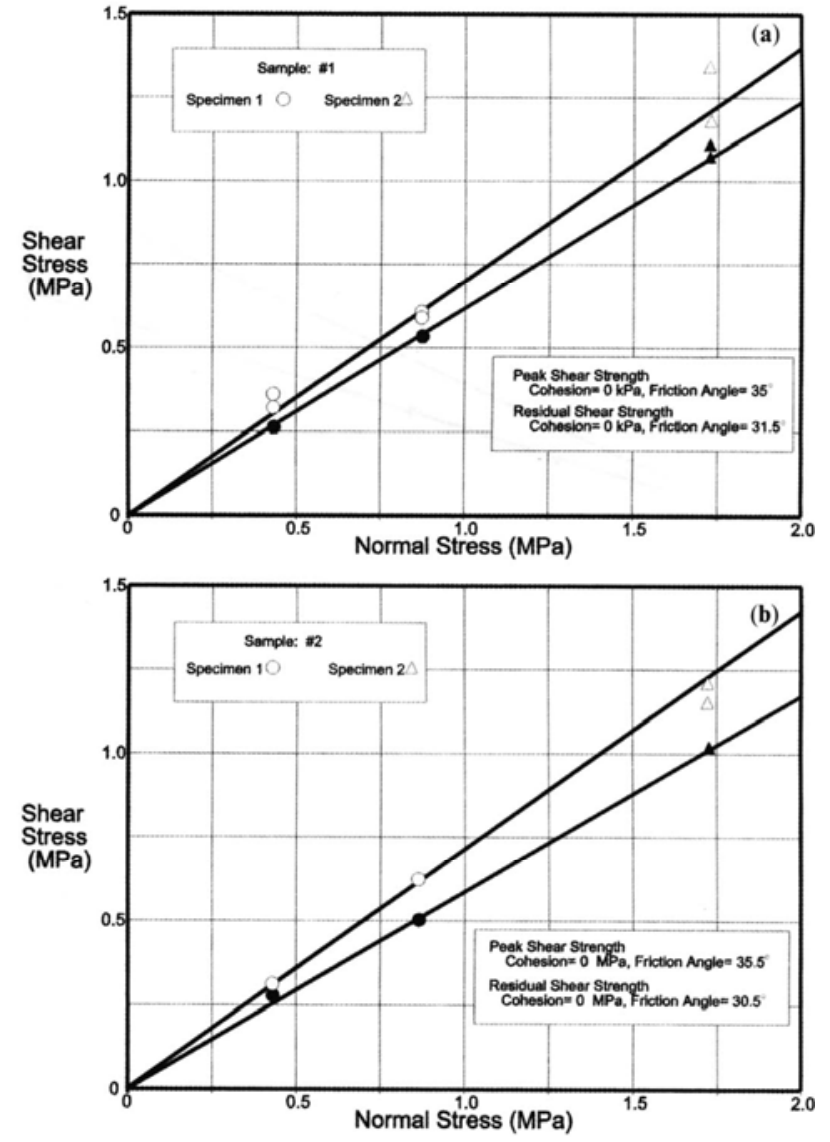

Fig. 33. Shear strength versus effective normal stress for edifice materials subjected to direct-shear tests, (a) Sample 1: Gages Wall tuff, altered. (b) Sample 2: Galway's Wall tuff. Open symbols show peak shear strength; filled symbols show residual shear strength.

outlined above. There are various ways in which these procedures can be manipulated, and the analyst needs to consider which methods are most accurate, and which of the accurate methods can be applied most easily (Duncan 1992, 1996: Fredlund 1984). A good comparative summary of the various methods is given by Bromhead (1986). The modified Bishop method was used in this work; the method satisfies moment and vertical force equilibria, and gives values of factor of safety $\mathrm{F}$ that fall within the range of equally correct solutions as determined by so-called exact methods (Duncan 1996; Bromhead 1986; Lambe \& Whitman 1969]. The method assumes a slip surface shaped as a circular arc, with material above this surface subdivided in a series of vertical slices for computation of body forces. As indicated previously, results for a specified slip

Table 1. Assumed material properties for limiting equilibrium analyses

\begin{tabular}{llcl}
\hline Material & $\begin{array}{l}\text { Unit weight } \\
\left(\mathrm{kNm}^{-3}\right)\end{array}$ & $\begin{array}{l}\text { Cohesion } \\
(\mathrm{kPa})\end{array}$ & $\begin{array}{l}\text { Friction angle } \\
(\mathrm{deg})\end{array}$ \\
\hline Model A & & & \\
1 & 20 & 1 & 39 \\
2 & 20 & 10 & 42 \\
3 & 20 & 1 & 39 \\
4 & 20 & 5 & 45 \\
Model B & & & \\
1 & 20 & 1 & 37 \\
2 & 20 & 10 & 42 \\
3 & 20 & 1 & 38 \\
4 & 20 & 5 & 45 \\
\hline
\end{tabular}




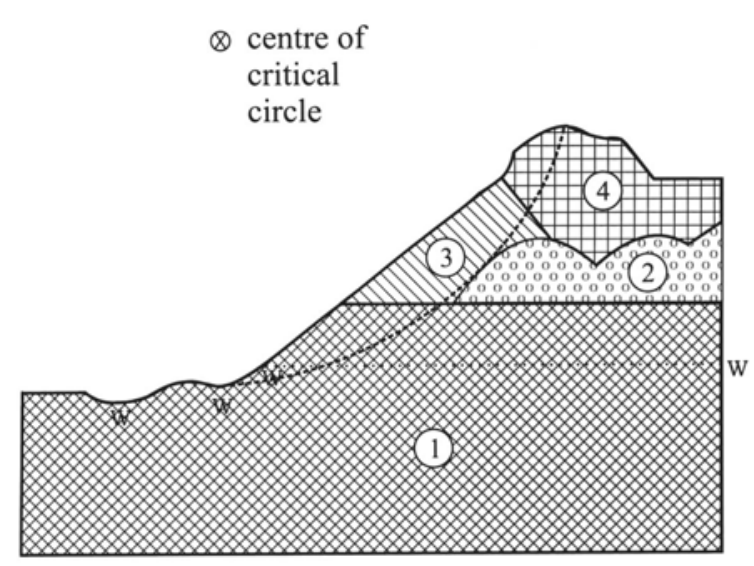

Fig. 36. North-south cross-section for Boxing Day collapse, showing materials and slip plane boundaries assumed in limit-equilibrium stability analyses. Material properties are given in Table 1 . The water table, indicated by the dotted line at ' $w$ ' joins the ground surface at the toe of the slope.

surface are summarized as a factor of safety, with the value $F=1$ implying incipient failure. In general, the $F$ for three-dimensional analysis is slightly greater than the $\mathrm{F}$ for two-dimensional analysis (Duncan 1992).

Table 1 lists material properties assumed, specific unit weights, and strength properties given by cohesions and effective-stress friction angles, varied selectively according to material type. The distributions of materials, and piezometric surface assumed, are shown in Fig. 36. A centre of rotation and radius was specified to represent the actual Boxing Day failure surface (assuming it to be circular), as inferred from construction of cross-sections (Fig. 12). The slip surface was assumed to be constrained by the south edge of the partly eroded Galway's Wall (Figs 36 and 9b).

Results of analyses for two similar sets of model properties (Table 1) are discussed here. The parameters represented bulk, aver- age properties assumed for these zones. However, we recognized that each zone was in fact heterogeneous and that local properties within a zone might differ substantially from the averages assumed. For model A the calculated safety factor $F$ for the Boxing Day surface was 1.22 under static loading, and 1.01 for applied seismic loading with pseudo-static seismic acceleration coefficient of 0.1 . Similarly, slightly weaker model B suggested $F=1.15$ under static loading, and $F=0.96$ for a seismic coefficient of 0.1 . These results could be interpreted to imply marginal stability for the static conditions considered. Small perturbations of applied loads, whatever the cause, could then bring the slope to a condition of failure. Such perturbations may be considered as the trigger mechanism, but the overall causes of failure are more complex and indeed include alt the various factors that brought the slope to its condition of marginal static stability (Voight \& Elsworth 1997, table 1). Prominent among these are the major topographic changes reflecting dome growth, wall erosion and talus deposition that occurred since 1996, as well as the history of hydrothermal alteration and possible episodes of prior slip.

Potential triggers included the direct effects of seismic shaking, pore-fluid pressure changes induced by seismic shaking or other mechanisms, strain-weakening by deep-seated creep, and loading by lava extrusion. A combination of these cannot be excluded. For example, increase of pore-fluid pressure in Galway's Soufriere materials (Fumarolic Unit source materials) to an artesian condition could have resulted in instability. This magnitude of pore pressure would require an average piezometric surface above the original ground, but such a circumstance cannot be discounted given the local presence in or under the soufriere of weak low-permeability clay layers, pre-existing shallow slip surfaces associated with landslides active in 1996 and earlier times, and the rapid loading of this area by dome-block talus in the weeks preceding the collapse. A low $F$ (near unity) could also have promoted localized creep of weak materials, and the deformation tests previously described indicated that some Fumarolic Unit materials were indeed characterised by relatively low frictional strength and profound strain-weakening. Thus, the static value of $F$ may have gradually decreased in the weeks preceding the failure.

However, in addition, the coincidence of the Boxing Day sector collapse with a brief period of enhanced seismicity, from 14:30 on
Fig. 37. Seismic data for 24-26 December 1997, for MBWH (Windy Hill, vertical component) seismic station (Fig. 2). (a) Number of earthquakes per hour. (b) Amplitudes of hybrid earthquakes as a measure of relative energy in units of $\mathrm{ms}^{-1}$. (c) Real-time seismic amplitude measurements (RSAM), in arbitrary.

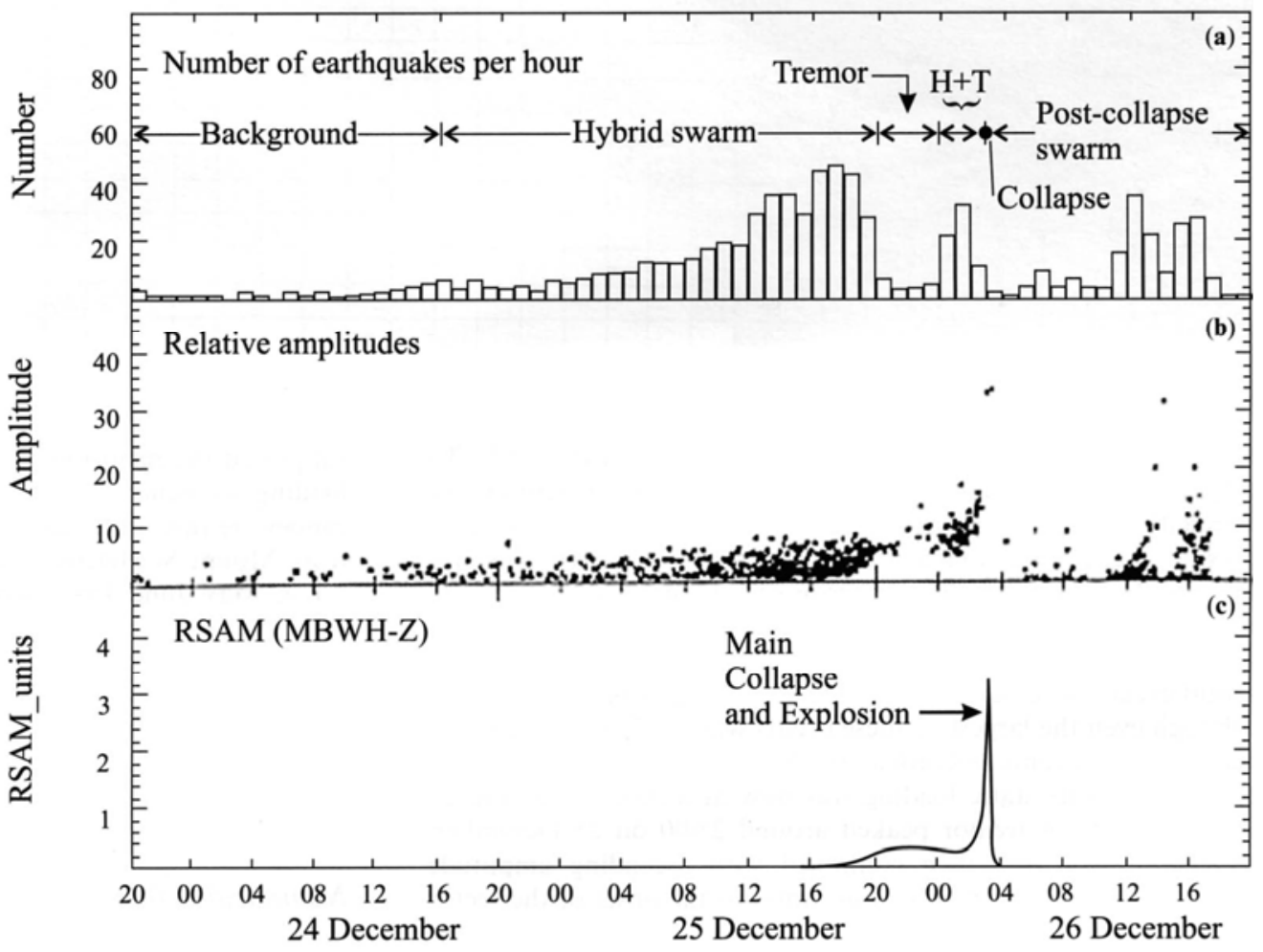

Time (Local Time) 

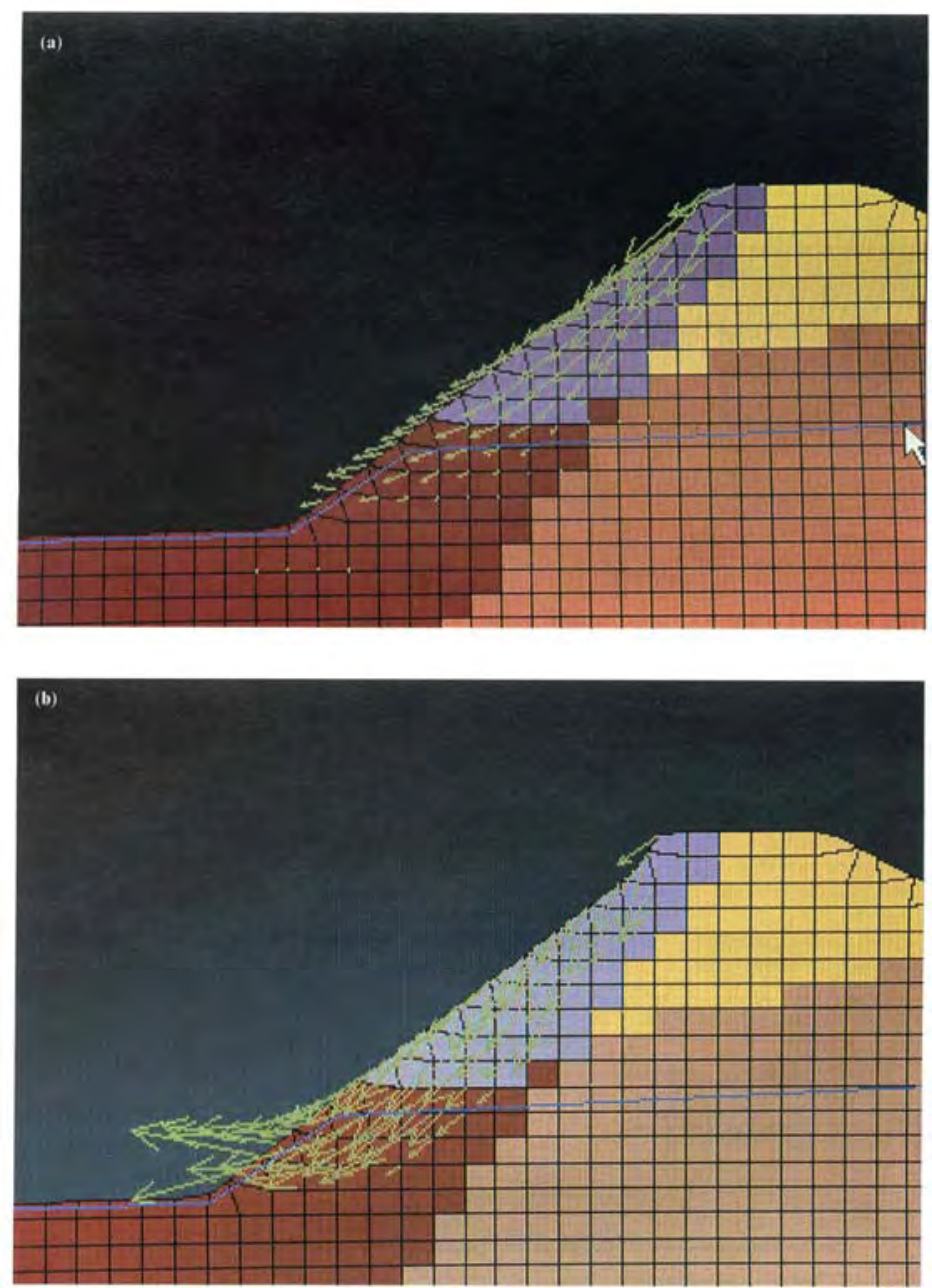

Fig. 38. Numerical model of north-south cross-section for BoxingDay collapse, seismic loading. (a) Material zones: 1. dome talus and

rockfall debris (purple); 2. fresh lava (yellow): 3. altered soufriere materials (brown): 4. old edifice materials (tan). White arrow marks the water table. Coulomb parameters assumed in zone 1 : $\mathrm{c}^{\prime}=10 \mathrm{kPa}, \delta^{\prime}=40^{\circ}$; zone 3 : $\mathrm{c}^{\prime}=50 \mathrm{kPa}, \delta$ $=40^{\circ}$ : other zones strong. Seismic loading coefficient, 0.15 . Movement indicated by velocity vectors, arrows ( $\max 0.037 \mathrm{~ms}^{-1}$ ) (b) As (a), with deformation accentuated from strain weakening. Zone 3: $\mathrm{c}^{\prime}=20 \mathrm{kPa}$, $\delta^{\prime}=20^{\circ}$.
24 December onwards, was probably not accidental (Fig. 37). To judge from previous periods of enhanced hybrid swarm activity, the seismicity was probably accompanied by an enhanced pulse of effusion of gas-charged lava (Voight et al. 1999). The hybrid swarm began with events every 20 minutes or so, and increased in intensity until the late evening on 25 December, after which the signal was effectively a tremor (Fig. 37; Sparks et al. 2002). The individual hybrid events increased in amplitude as the swarm progressed, and, although even the largest of these events was smaller in magnitude than similar events recorded in November 1997, the sector geometry and its static loading was now at a more critical level. The amplitude of tremor peaked around 23:00 on 25 December, declined briefly, and then continued with ascending amplitude (roughly doubling the previous maxima) to the onset of the sector collapse at 03:01 (Fig. 37).

The near-coincidence of distinct hybrid seismicity with the sector collapse was suggestive of a possible causative relation, and supported the inclusion in the modelling of transitory earthquake loading by equivalent static forces. Strong-motion data on volcanoes are rare, although Voight et al. (1983) reported information from Mount St Helens, and such data were acquired at Montserrat in May-June 1997, when ground accelerations measured on Chances Peak from shallow hybrid earthquakes were as much as $0.1 \mathrm{~g}$ (B. Voight, unpublished data). The accelerations associated with earthquakes in December 1997 may not have been this severe, but we nevertheless have explored the use of pseudostatic seismic coefficients of about 0.1 for analyses of the 26 December 1997 sector collapse.

\section{Numerical deformation models}

The modelling work of 1996-1998, considered above, was of limited applicability in that stress strain behaviour, development 


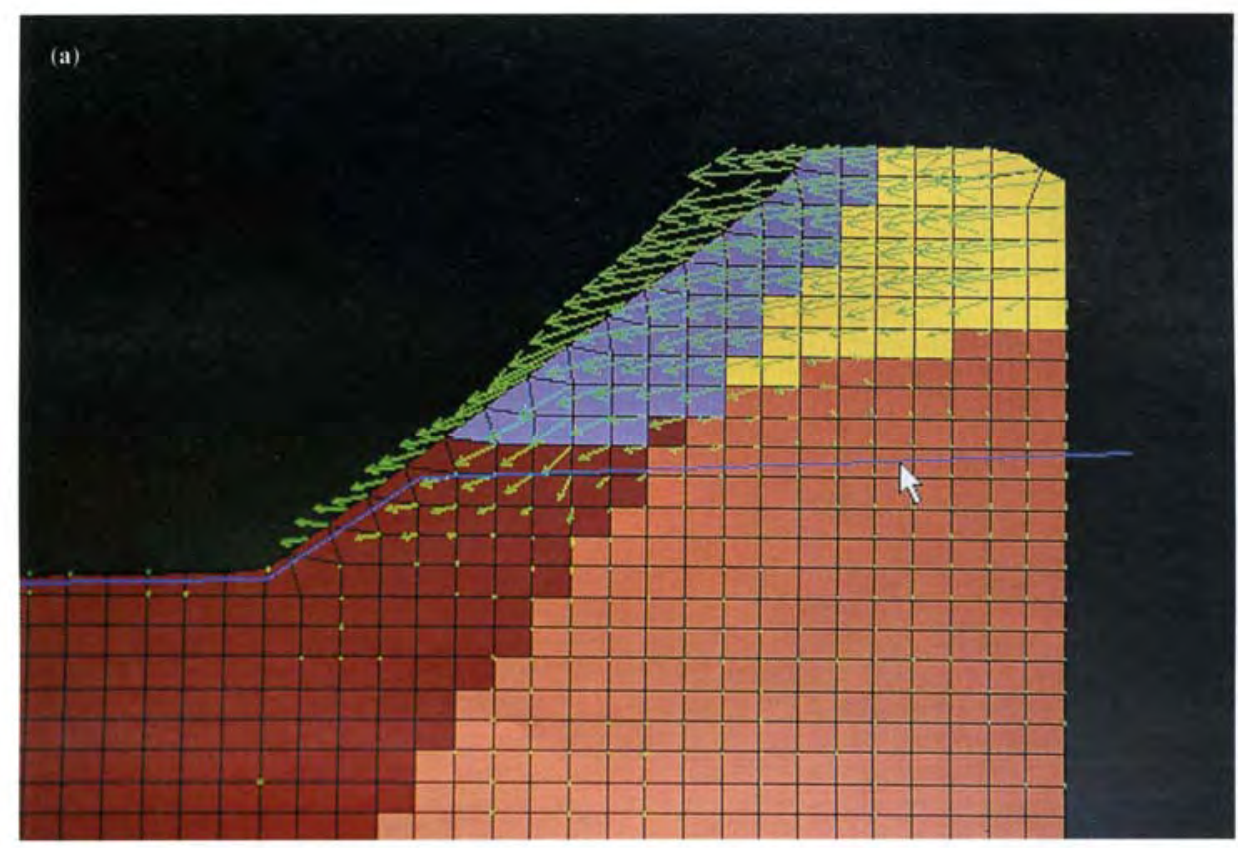

Fig. 39. Numerical model of lava shearlobe emplacement at Soufriere Hills. (a) Lava in the upper part of the slope (yellow) is pushed southwards (to left) at at a constant rate, and creates a velocity field (vector arrows, max $0.65 \mathrm{~ms}^{-1}$ ).

(b) The velocity field creates a shear zone that extends lo the toe of the slope and includes altered soufriere material. The deformed grid illustrates the displacements; the shear strain-rate field is shaded. Grid distortion scale is $190 \mathrm{x}$. Zone at toe of slope is soufriere material that is susceptible to strain-weakening. with effects shown in Figure 40.

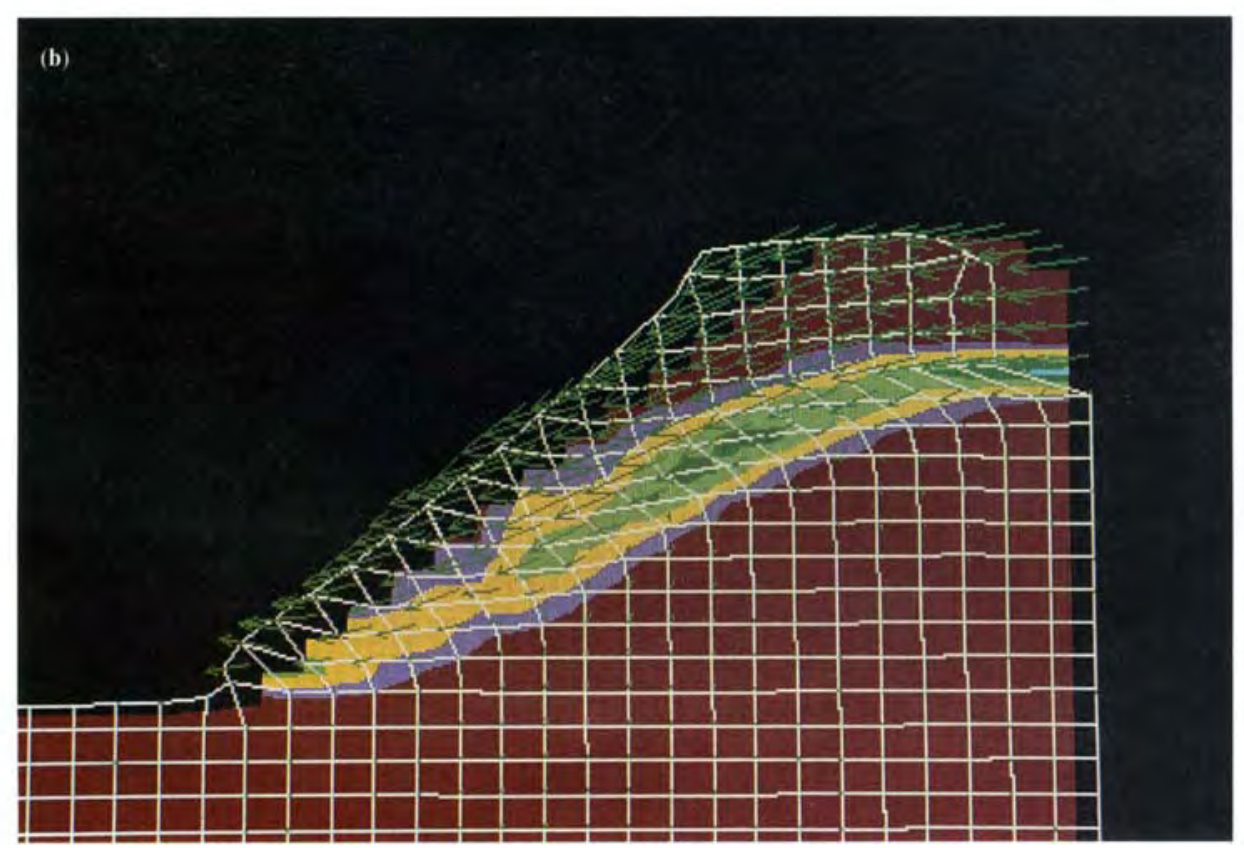

of plastic zones and strain-weakening, and dynamic loading, among other aspects, could not be adequately represented by the methods employed. It is preferable that the mechanism of failure should be elucidated by modelled strain localizations, rather than prespecified as in limiting-equilibrium analyses, or vaguely interpreted from elastic models. The previous results did not preclude seismic shaking as a trigger mechanism, but the methods did not facilitate consideration of some other potential causes, such as enhanced conduit pressure, strain-weakening, and the invigorated emplacement of a fresh shear-lobe of lava. In order to illuminate these issues, we evaluated a series of two-dimensional explicit plain-strain finite difference models of the Soufriere Hills slope, using the Fast Lagrangian Analysis of Continua procedure (Cundall \& Board 1988: Coetzee et al. 1998; Detournay \& Hart 1999).

The slope was subdivided into four zones, representing (1) fresh dome talus, (2) fresh lava, (3) altered soufriere material, (4) old edifice, as shown in Figure 38. with the actual material parameter values different in various models. In general the bulk modulus was taken as 20GPa and shear modulus was $10 \mathrm{GPa}$. The models could undergo plastic deformation when Coulomb yield limits were reached, which are different in the various zones. In some cases pseudo-static loads were used to simulate earthquake loading. Figure 38a shows assumed material zonation and displacement/ velocity vectors for the slope subjected to seismic loading, with Figure $38 \mathrm{~b}$ showing enhanced deformation after strain-weakening. As the velocity and strain fields appeared to be more or less consistent with the deduced position of the actual failure surface at Montserrat (Fig. 12), the results did not preclude the hypothesis of seismic shaking alone as a trigger of the Boxing Day sector collapse. The lava shear-lobe emplacement hypothesis was treated next, whereby lava in the upper part of the slope was displaced southwards at a steady rate, creating a shear zone that extended to the toe 

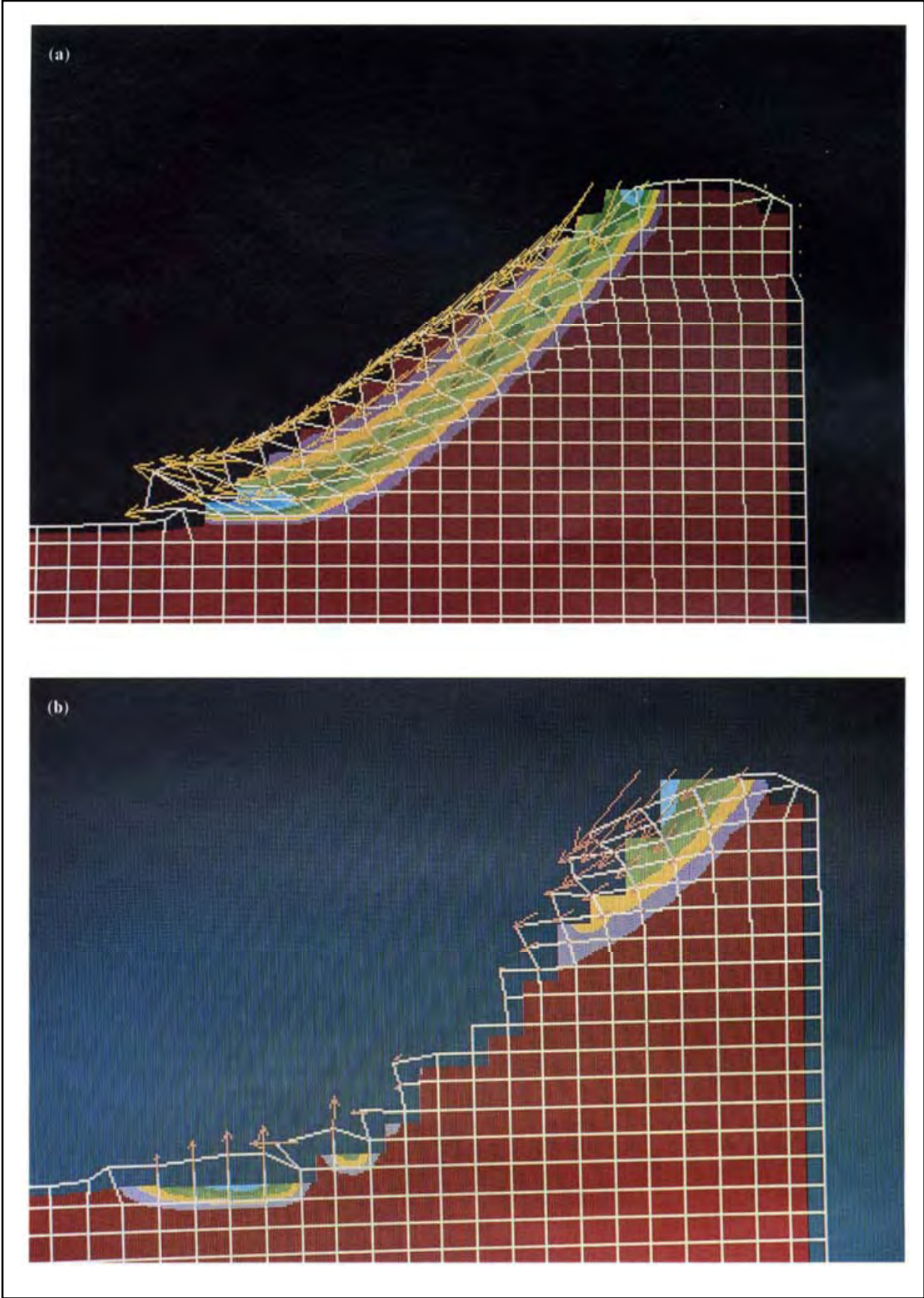

Fig. 40. (a) As Figure 39, with material in outer slope strain-weakened to: $\mathrm{c}^{\prime}=$ $20 \mathrm{kPa}$, phi' $=30^{\circ}$ in zone 1 (talus and rockfall debris); and $c^{\prime}=20 \mathrm{kPa}$, phi' $=$ $20^{\circ}$ in zone 3 (soufriere material). Lava-lobe emplacement still continues as in figure 39 (note grid distortion at upper right), but gravity-driven movements on outer slope dominate the grid distortion, shear strain-rate and velocity vector field. Grid distortion scale $24 \mathrm{x}$, max. vector $5.0 \mathrm{~ms}^{-1}$. (b) Gravity collapse of the outer part of the slope results in an oversteepened and decompressed face of fresh lava, which begins to collapse (grid distortion scale $1.1 \mathrm{x}$ ). Generation of the decompression-induced explosions is beyond the scope of the model.

of the slope and included altered soufriere material (see velocity field, Fig. 39a. and shear zone, Fig. 39b). In this model, shear-zone materials in zones 1 and 3 were assumed to strain-weaken, so that spontaneous, localized gravitational collapse might then occur in the outer slope (Fig. 40a). The deformation rates due to gravitational loading exceeded those associated with the southerly displacement due to continuing lava shear-lobe emplacement (Fig. 39b), thus promoting the gravity collapse. This, in turn, resulted in an oversteepened and decompressed face of fresh volatile-rich dome lava, which began to collapse, in part explosively, and to generate a violent pyroclastic density current (Fig. 40b). The details of the explosive initiation are beyond the scope of this type of model, but are explored by Fink \& Kieffer (1993), Alidibirov \& Dingwell (1996), Voight \& Elsworth (2000) and Woods et al. (2002). In general, these models suggest that increased loading and strain-weakening deformation induced by lava lobe emplacement are viable trigger mechanisms for the Boxing Day sector collapse: some influence of superposed seismic loading is not excluded.

Edifice stresses resulting from conduit pressure could also be modelled, although these stresses dissipate radially and a two-dimensional model only provides an upper bound to the stresses. There were no field observations that suggested that propagation of brittle shear fractures occurred in a fashion that would connect an outer-flank collapse with stressed rock surrounding the pressurized conduit. Overall the analyses seemed to favour (1) collapse triggered by a pulse of rapid lava shear-lobe emplacement, with subsequent gravity-driven slip-surface localization influenced by enhanced loading, creep and strain-weakening, and/or (2) seismic shaking. We favoured a combination of the two mechanisms, inasmuch as lobe emplacement was accompanied by seismicity which may have 
changed the distribution of stresses, and the seismicity itself was not particularly strong in comparison with previous seismic episodes and thus may not have been the exclusive trigger.

\section{Numerical modelling of dynamics of debris avalanche emplacement}

\section{Assumptions}

The dynamics of the debris avalanche motion have been evaluated by numerical modelling (Heinrich et al. 2001). In these studies: (1) the avalanche was idealized as the flow of a homogeneous incompressible continuum due to its observed, macroscopic fluid-like behaviour; (2) bed erosion was neglected: (3) mass and momentum conservation equations were depth-averaged over the flow thickness, since the characteristic length of the avalanche was much larger than the thickness; (4) energy dissipation within the flow was neglected and the slope-parallel velocity was assumed approximately constant over the thickness (Savage \& Hutler 1989); and (5) longitudinal gradients of the deviatoric stress were neglected throughout the flow. The governing equations used a slope-parallel and slope-normal co-ordinate system (Heinrich et al. 2001).

Basal friction was modelled by Coulomb-type friction laws, where $\delta$ is the friction angle between the rough bed and the mass. The friction angle could be assumed to be constant, independent of the shear rate (Savage \& Hutter 1989; Naaim et al. 1997) or defined as a function of both the velocity $(u)$ and the height of the flow $(h)$ (Pouliquen 1999). In the case of a constant friction angle, a constant ratio of the shear stress to the normal stress at the base was assumed, similar to a friction law for a rigid block on an inclined plane. Pouliquen (1999) argued that the constant friction assumption failed for granular flows over rough bedrock, and proposed an empirical friction coefficient $\mu=\tan \delta$ as a function of the Froude number $(u / \sqrt{ }(g h))$ and the thickness $h$ of the granular layer:

$$
\mu(u, h)=\tan \delta_{1}+\left(\tan \delta_{2}-\tan \delta_{1}\right) \exp (-\mathrm{h} / \mathrm{D} x \sqrt{ }(\mathrm{gh}) / \mathrm{u})
$$

where $\delta_{1}, \delta_{2}$ and $D$ are characteristics of the material that in principle could be measured from deposits. Extrapolating Pouliquen's results to real avalanches, very approximately $D=7 d$, where $d$ is the 'effective mean diameter' of flowing material. The equation provides a friction angle ranging between two values $\delta_{1}$ and $\delta_{2}\left(\delta_{1}<\delta_{2}\right)$, depending on the instantaneous values of the velocity and thickness of the flow. The higher the velocity, the higher is the friction.

\section{Numerical emplacement models}

The numerical model was based on a shock-capturing method, similar lo those used to simulate shock waves in compressible flows, which appeared to be stable and accurate in other applications (Mangeney et al. 2000; Heinrich et al. 2001; Assier et al. 2000). The method is a one-dimensional Lagrangian approach, based on a high-order Godunov-type scheme as discussed by Heinrich et al. (in press). The landslide is initialized in the simulation by a parabolic shaped solid with volume of $50 \times 10^{6} \mathrm{~m}^{3}$ released from rest.

A first series of numerical simulations was performed using the simple Coulomb friction law, for different values of the basal friction angle. The best agreement was obtained for $13^{\circ}<\delta<15^{\circ}$ (Heinrich et al. 2001). However, with this model a steep flow snout was absent, contrary to the field observations, and the model overspill areas located west of the White River valley did not correspond well to the field observations. In a second series of simulations, using Pouliquen'is friction law. the observed phenomena were approximately reproduced for $\delta_{1}$ around $10^{\circ}, \delta_{2}$ around 20 and assumed mean diameters of the order of $1 \mathrm{~m}$ (Fig. 41). By trial and error, the friction angles $\delta_{1}$ and $\delta_{2}$ were chosen respectively at $11^{\circ}$ and $25^{\circ}$, with $d$, the theoretical mean particle diameter, ranging from $1.35 \mathrm{~m}$ to $2.6 \mathrm{~m}$. Model velocities were comparable with the field estimates as discussed above. For effective mean diameters $d<2.2 \mathrm{~m}$ the avalanche overtopped the west bank of the White River valley and flowed for an excessive distance (Fig. 41c). For $\mathrm{d}>2.2 \mathrm{~m}$ the deposit area was somewhat smaller than observed. The calculated runout distance was partly dependent on the mean diameter, with a difference of $300 \mathrm{~m}$ obtained between solutions for $d=1.35 \mathrm{~m}$ and $2.6 \mathrm{~m}$.
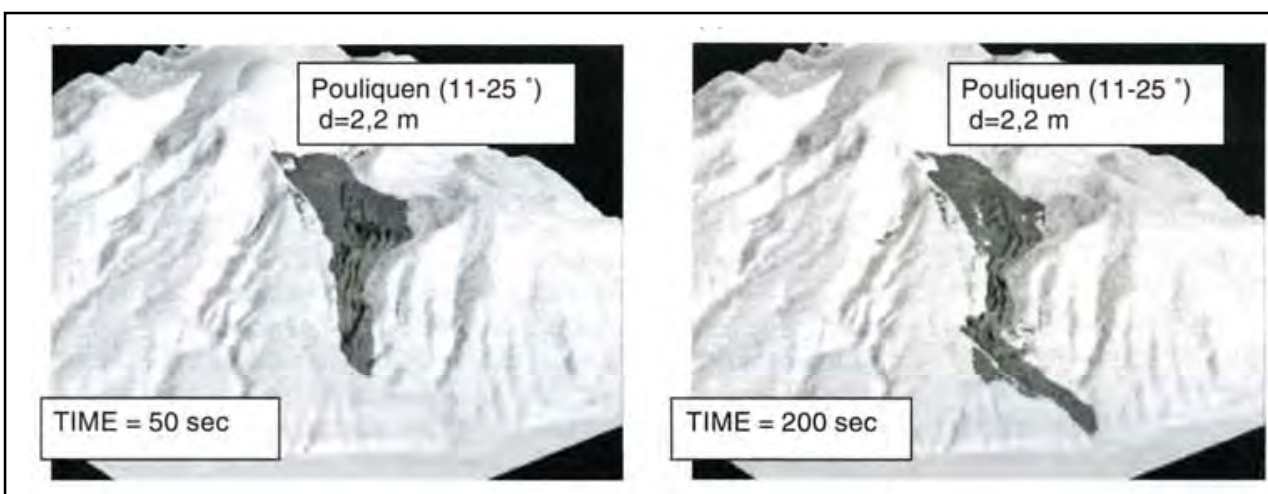

(c)

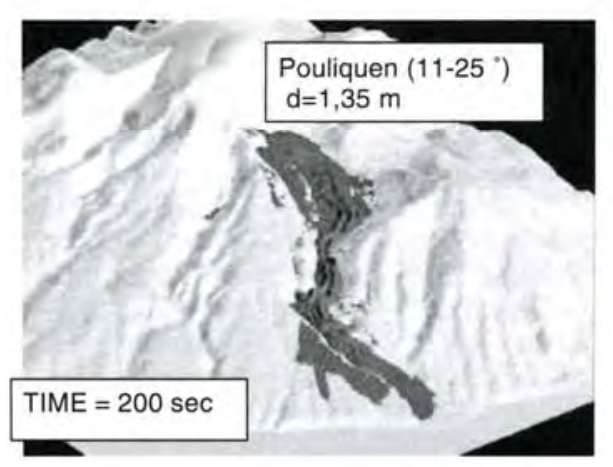

(d)

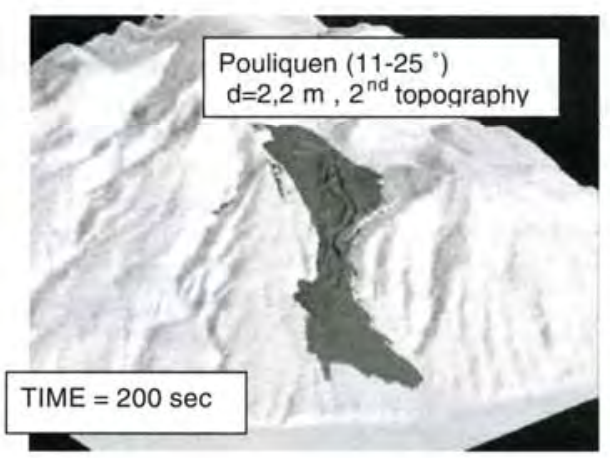

Fiy. 41. (a, b) Flow evolution for Pouliquen's friction law with $\delta_{1}=11^{\circ}$ and $\delta_{2}=25^{\circ}$, and a mean particle diameter $\mathrm{d}=2.2 \mathrm{~m}$. (e) Flow position at $\mathrm{t}=200 \mathrm{~s}$ for the same angles $\delta_{1}$ and $\delta_{2}$ and $d=1.35 \mathrm{~m}$. (d) Flow position at $\mathrm{t}=200 \mathrm{~s}$ for the same rheological parameters (a) and (b) but using a new topography with a partial filling of the White River valley. 


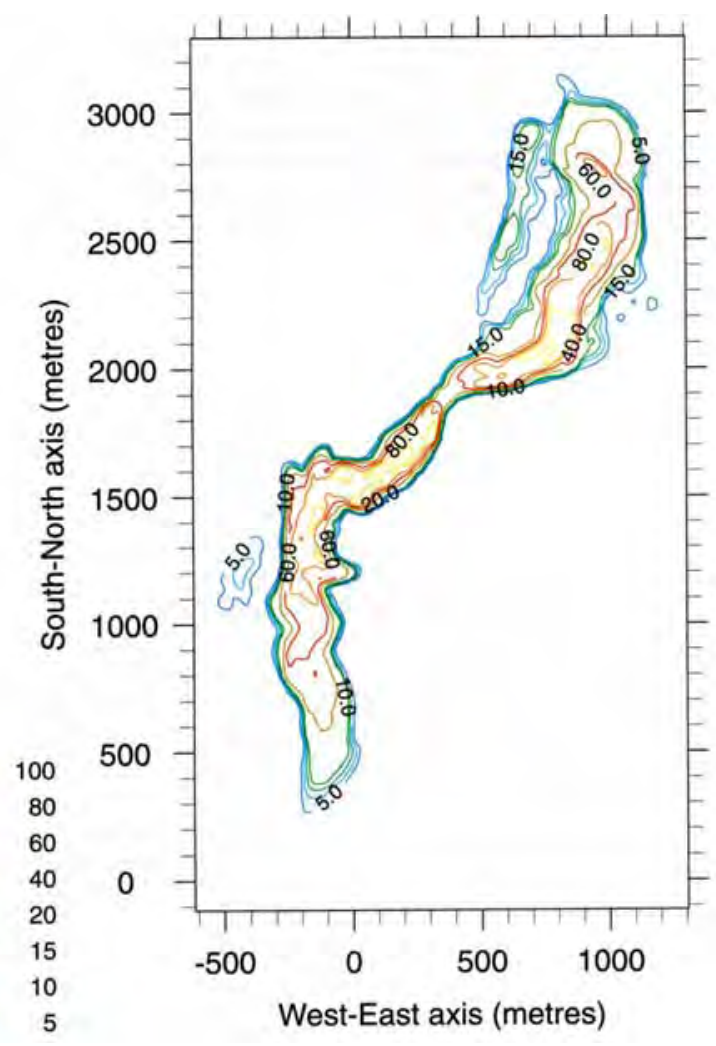

Fig. 42. Deposit thicknesses (in) calculated by Pouliquen's friction law with $\delta_{1}=11^{\circ}$ and $\delta_{2}=25^{\circ}$ and a particle diameter $d=2.2 \mathrm{~m}$.

A good general agreement was obtained with deposit thicknesses (Fig. 42). West of the Fergus Mountain bend, the maximum model deposit thickness was about $10 \mathrm{~m}$, fairly close to that observed. In the valley, deposit thicknesses ranged from 7 to $60 \mathrm{~m}$ for distances of 300 to $800 \mathrm{~m}$ from the sea, with a more pronounced frontal snout (c. $20 \mathrm{~m}$ ) than for models calculated by simple Coulomb friction. The simulated avalanche stopped $200 \mathrm{~m}$ from the shoreline.

A final simulation was carried out to estimate the influence of topographic changes in the valley. Starling with pre-eruption topography, the valley was then arbitrarily filled to 0.75 depth before releasing the avalanche volume. Numerical results are presented in Figure 41d for Pouliquen's law with friction angles between $11^{\circ}$ and $25^{\prime}$ and $\mathrm{D}=2.2 \mathrm{~m}$. The results at $\mathrm{t}=200 \mathrm{~s}$ showed that overspill flow at the Fergus Mountain bend was accentuated, and resulting overspill deposit areas were very large. The volume passing the bend in the valley was then smaller, and so smaller thicknesses were obtained in the lower part of the White River valley. As a result of thickness reduction, the angle $\delta_{2}$ was activated, which finally led to shorter runout. Thus, in this case, partly filling up the valley and smoothing topography did not lead to greater downstream velocities and runout, and smaller deposit thicknesses were obtained at the lower end of the valley. However, this counterintuitive result cannot he generalized, as less extreme filling might have reduced localized roughness of the channel floor, and yet not have facilitated an excessive overspill; in this case, intuition would have correctly suggested an increased runout.

\section{Discussion of model results}

The best agreement was obtained for a model using Pouliquen's friction law, with an assumed effective mean diameter of $2.2 \mathrm{~m}$ and friction angles varying from $11^{\circ}$ to $25^{\circ}$. This best-fit model-based particle diameter was greater than the median size of small-volume samples, and was perhaps also larger than field values even if much larger sample sizes were considered, although we must also recognize that fragmentation occurred during the flowage process (cf. Ui et al. 1986). In part this result may reflect the very small range of sizes considered in the original Pouliquen analysis, and also the need to extrapolate the size calibration procedure lo very poorly sorted materials. Comparisons between flows calculated by Coulomb and Pouliquen's friction laws have shown the importance of the dependence of the friction angle on the Froude number and the flow thickness. The Pouliquen model gave results in better agreement with thicknesses observed in the field than those calculated by a simple Coulomb law. This result suggests a shear-rate dependence in the mechanical behaviour of debris avalanches, or at least the action of a second parameter. Irrespective of the friction law used, the empirical value of the apparent friction angle required to reproduce the significant mobility of the Boxing Day avalanche in Montserrat was low $\left(\delta<15^{\circ}\right)$, in general agreement with the widely observed but poorly understood apparent excess mobility of large debris avalanches (Voight et al. 1985). At Montserrat, as at Mount St Helens (Voight et al. 1983), pore-water pressure in disaggregated, fumarolically altered debris probably partly accounted for enhanced mobility. For water-saturated materials, the apparent friction coefficient is a function of the actual friction coefficient and the pore-fluid pressure (Voight 1978, pp. 154-155; Sassa 1988; Voight \& Elsworth 1997, pp. 11-14).

Geotechnical testing of avalanche debris at Montserrat suggested effective-stress friction angles for sandy textured debris of $25-35^{\circ}$ (peak) and $17-25^{\circ}$ (residual), with minor cohesive strength The apparent friction values for these materials in a flowing avalanche associated with high pore-water pressures would be much reduced, and more consistent with modelled values. In addition, local seams of clay-rich materials have measured low frictional strength $\left(3-14^{\circ}\right)$. Such materials are only found locally and probably do not account for bulk avalanche mobility, although it may be noted that failures in nature preferentially select the weakest materials.

The ratio of fall height to runout distance $(\mathrm{H} / \mathrm{L})$ for the avalanche was about 0.22 (Fig. 25). This ratio can be crudely interpreted in terms of the apparent friction coefficient of the avalanche (Pariseau \& Voight 1979), and thus the apparent friction angle is around $12-13^{\circ}$. This result suggests that much of the initial potential energy was consumed by basal friction (Hutter 1996), and that local topography variations did not too strongly influence runout.

These results contrast with those of Dade\& Huppert (1998), who suggest from scaling relationships that a constant-stress resistance law applies to long-runout mass movements. Our experimental and modelling results suggest that this resistance is not constant, but instead is related by friction coefficient to the varying thickness of the avalanche during emplacement. The Pouliquen relation suggests further that resistance may also be related to velocity. The Dade \& Fluppert result possibly can be rationalized by the view that an average resisting stress can be defined, and is approximately proportional to the average thickness of an avalanche. However, in detail, this thickness will vary considerably from point to point and from time to time during the emplacement process, and the resisting stresses will also vary in a corresponding way.

\section{Comparisons and contrasts}

Comparisons of the Boxing Day sector collapse and dome explosion with the well documented May 1980 edifice collapse and cryptodome explosion of Mount St Helens, USA, and the March 1956 collapse and explosion of Bezymianny in Russian Kamchatka, seem particularly relevant. All three complex events, edifice failures and explosions, are of Bezymianny-type (Gorshkov 1962; Siebert et al. 1987; Voight \& Elsworth 1997), meaning that an injection of magma had preceded and probably had prompted the sector collapse. A similar event at $c$. $3000 \mathrm{BP}$ has been postulated for Soufriere Volcano in neighbouring Guadaloupe (Boudon et al. 1984). 
In all these events, a sector collapse preceded and triggered the generation of energetic pyroclastic currents. Al Mount St Helens, dacite magma was intruded asymmetrically early in the eruption, as a cryptodome into the interior of the stratovolcano (Lipman \& Mullineaux 1981). The high-viscosity intrusion caused marked deformation of the north slope at rates of $c .2 \mathrm{~m}^{-1}{ }^{-1}$ (Lipman et al. 1981), which caused much concern for the USGS observatory team. In an interpretation one month in advance of the collapse, prompted by qualitative observations of the deformation, the possibility of a massive sector collapse and an accompanying pyroclastic explosion was recognized (Voight 1980, 2000; Decker 1981). On 18 May 1980, after several months of significant deformation and seismicity - but without recognized short-term precursors such as accelerating deformation or seismicity - sector collapse occurred retrogressivery to generate a complex debris avalanche. This in turn facilitated a devastating laterally directed explosion that evolved contemporaneously with the later movement stages of the avalanche (Voight et al. 1981, 1983; Glicken 1986, 1998; Fisher et al. 1987; Sousa \& Voight 1995; Hoblitt 2000). A moderately large $(M=5)$ earthquake occurred at the time of slope collapse and was generally interpreted to have triggered it.

In the case of Bezymianny in 1956, andesitic magma was intruded into the edifice as much as six months before slope collapse, and frequent minor magma tic explosions had occurred. Massive deformation of the volcano slope by intruding magma preceded sector collapse of the edifice (Gorshkov 1959). Failure there too was associated with an earthquake, and collapse probably occurred rctrogressively (Voight \& Elsworth 1997) to generate a massive volcanic debris avalanche, and a violent laterally directed explosion (Belousov \& Bogoyavlenskaya 1988; Belousov 1996). No detailed monitoring had been attempted, bul large earthquakes were detected by the regional seismic network.

In contrast, at Soufriere Hills Volcano a dome of pressurized andesitic lava built up over the south flank, and this, with talus shed by the dome, loaded a weakened (and eroded) area of altered rock that included active hydrothermal springs. Seismic precursors preceded the failure in the short term. The sector collapse undermined the pressurized dome, and thus the debris avalanche was succeeded by a destructive, laterally directed pyroclastic current. The collapse occurred at a mature stage in the eruption, which started about 2.5 years earlier, but signs of potential structural instability had developed over a year before and recognition of these signs had led to effective risk mitigation.

The common factors in these three events are a relatively weak, partly altered edifice further destabilized by emplacement of silicic magma containing pressurized volatiles, and subjected to dynamic seismic loading. However, the differences are also substantial. It appears that the Soufriere Hills example falls into a separate class involving exogenous shear loading by extruding lava above a hydrothermally weakened flank, in contrast to endogenous stressing of the edifice by an intruding cryptodome (Donnadieu \& Merle 1998, Voight 2000).

Further, although large earthquake shocks occurred at Mount St Helens and Bezymianny, no such large individual triggering shocks were detected at Soufriere Hills; instead the sector collapse was preceded by a seismic swarm and tremor of many hours' duration. The Boxing Day events illustrate the potential for highly dangerous activity in all dome eruptions where hydrothermal alteration related to earlier episodes of volcanic activity has created a weakened edifice, and where high gas pressures in the interior of a dome lava and/or conduit can contribute to destabilization (Voight \& Elsworth 2000), and can also generate violent pyroclastic currents if the edifice fails.

The Socompa debris avalanche, northern Chile, as studied by our deceased co-author and friend Peter Francis and his associates (Francis et al. 1985; Francis \& Self 1987; van Wyk de Vries \& Francis 1996), offers other significant comparisons. The Socompa sector collapse (c. $7000 \mathrm{BP}$ ) reflected loading of weakened base material by the growing volcano (van Wyk de Vries et al. 1999), which caused outward spreading in the substrate prior to collapse. A somewhat similar process may have occurred at the base of the rapidly growing talus cone at Montserrat. It is conceivable that loading under undrained conditions there (in saturated strata of low permeability) promoted creep movement and strain-weakening that influenced the flank failure.

Some volcanoes, such as Mount St Augustine (Alaska), Shiveluch (Kamchatka, Russia) and Egmont (New Zealand) have collapsed repeatedly (Beget \& Kienle 1992; Belousov et al. 1999; Ui et al. 1986; Palmer et al., 1991). Work by Boudon et al. (1999) and Deplus et al. (1999) has shown that volcanoes in the Carribbean arc also have been prone to sector collapse in the past. At least eight collapses have been recognized at Soufriere Volcano, Guadeloupe, where continuous vigorous hydrothermal activity, over thousands of years, has considerably modified the structure and mechanical properties of an edifice periodically affected by phreatic eruptions and less frequent magmatic dome eruptions. Indeed, the Boxing Day sector collapse at Soufriere Hills Volcano repeats, in general terms, a phenomenon that occurred there several times before, with English's Crater representing the scar of a major prehistoric debris avalanche, and with extensive hummocky avalanche deposits offshore (Boudon 2001).

\section{Discussion: evolution of the sector collapse}

\section{Monitoring and mitigation}

The 26 December sector collapse at Soufriere Hills Volcano illustrated that a major edifice failure and directed explosion could occur, despite relatively intensive monitoring, without precursors sufficiently diagnostic to enable reliable short-term forecasting. Nevertheless, the potential for a collapse and explosion of this general kind at Montserrat was recognized over a year before its occurrence, which led to a precautionary evacuation. Consequently there were no casualties, despite the unmistakable violence of the events (Sparks et al. 2002). Further, the recognition of a pattern of enhanced volcanic activity every six to seven weeks from May 1997 onwards (Voight et al. 1998, 1999) enabled anticipation by the Montserrat Volcano Observatory team that a significant event or series of events might take place towards the end of December 1997. Further discussion of the hazards assessments and their implications are reported by Young et al. (2002).

\section{Causes of the collapse}

The 26 December sector collapse was caused by some combination of long-term alteration-weakening by hydrolhermal activity, subsequent dome lava and talus loading of the (partly) water-saturated materials, and shaking associated with volcanic seismicity. Static conduit-magma prcssurization seems unlikely as a major direct influence on failure, but might have been indirectly related, for instance as a factor in the production of hybrid seismicity (Voight $e t$ al. 1999). The rapid south-directed exogeneous growth of a shear-lobe of dome lava, and shedding of lava-block talus over the Galway's Wall and Galway's Soufriere area since early November 1997 provided quasi-static loading and perhaps also pore-fluid pressure enhancement that strongly contributed to failure. These loads may have been applied in undrained fashion (in the geotechnical sense; see Lambe \& Whitman 1969) to pockets of water-saturaled, weak, low-permeabilily, fines-rich alteration materials. Seismic loading may have augmented the destabilization forces in the 24 hours (especially the last few hours) prior to the sector collapse, in concert with the load changes caused by rapid effusion and endogenous dome lava emplacement.

Thus, although the sequence of night-time failure events was not observed and is imprecisely known, an episode of rapid effusion accompanied by the shallow seismicity of 24-26 December probably provided the trigger for localized base shear-failure of the hydrothermally weakened hill of tuff between Galway's Soufriere and the deteriorated Galway's Wall. Possibly, this hill may have comprised a toreva block from a prehistoric sector collapse in the 
While River valley, such that a partial slip surface already existed and merely required reactivation. Failure was probably progressive. With strain-weakening causing the shear resistance in the altered material to approach residual strengths, the slip surface propagated northwards through talus to the top of the lava dome, and broke out southwards through a toe at Galway's Soufriere while becoming detached on lateral margins.

Strain-weakening behaviour is indicated by the laboratory tests, with the residual friction angle results varying widely, from $3^{\circ}$ in clay to $31^{\circ}$ in tuff. A typical friction angle for the avalanche debris may be between these extremes (e.g. sample 2A), but it should be recognised also that failure processes arc selective, and thus the weakest units could strongly influence the failure, even if they did not represent a large volumetric proportion of the materials that failed.

\section{Flow behaviour}

Most of the detached mass accelerated under the impetus of gravity, and moved rapidly as a disintegrating, shearing avalanche down the White River valley. In these movements the source region tended to fragment along weak layers and boundaries, forming avalanche megablocks, which subdivided further at weak boundaries during transport. The strength of the avalanche was effectively governed by the weakest lithologies and weak zones.

Much of the megablock facies material was more or less cohesive, with the overlying talus non-cohesive. This difference probably resulted in non-uniform avalanche flow behaviour, although the possibility is enigmatic to assess because of difficulty in identifying some talus materials from blocky pyroclastic flow deposits. The debris avalanche flow was unsteady, with several flow pulses implied by channel overtopping relations and by lobate forms on the deposit surface. Movement of following material was arrested as, at several locations, debris slowed in front, and transverse steps were formed similar to those described for volcanoes Socompa (Wadge et al. 1995), Avachinsky (Castellana et al. 1995) and Shiveluch (Belousov et al. 1999). In turn, the sector collapse resulted in an oversteepened front of the fresh lava dome, which caused it to disintegrate, partly by gravity but also by release of external loads on the gas-pressurized lava, and to form a pyroclastic current that ravaged the south flank.

The shear tended to be focused towards the base of the avalanche, accounting for the basal shear fabric, and for the transport of little-deformed megablock facies. Nevertheless, both compressional and dilational strains affected the avalanche debris at different places and times, and with increasing distance there was enhanced clast shattering, clast-size reduction, and mingling of coloured units. The textures mainly suggest emplacement by laminar flow, with interaction between megablock domains dominated by near-neighbour compression and shearing.

\section{Emplacement dynamics}

Insights into the dynamics of avalanche emplacement were provided by three-dimensional numerical simulations, with the avalanche idealized as a flow of a homogeneous continuum governed by a basal friction law. The dominance of basal friction is fully justified by the fabric and structural observations discussed above. Numerical results showed that the observed distribution of debris, including overspill deposition, is well reproduced for an assumed Coulomb-type (Pouliquen) friction law with a friction coefficient dependent upon the thickness and the velocity of the flowing mass.

The low values of friction implied by numerical modelling are consistent with the fact that large avalanches travel farther than expected from overly simple models of slope failure. The mobility of this avalanche may have been enhanced by the presence of water-saturated, highly altered material from the Galway's fumarolic system, which constituted a large portion of the avalanche. For such water-saturated materials, the apparent friction coefficient is a function of both the actual friction coefficient and the pore-fluid pressure (Voight 1978; Sassa 1988; Voight \& Elsworth 1997). Furthcr, as discussed above, avalanche transport dynamics are strongly influenced by weak lithologies and weak /ones.

The best-fit dynamic model suggested an avalanche emplacement time of less than three minutes and typical maximum velocity of about $40 \mathrm{~ms}^{-1}$. These data are consistent with estimates based on field constraints, which suggest a probable emplacement time of $138 \mathrm{~s}$ or more, dependent on location, and an average speed in excess of $19-55 \mathrm{~m} \mathrm{~s}^{-1}$. The numerical results illustrate the potential of such models to evaluate the capability of debris avalanches to surmount relief and to affect areas beyond the obvious drainage channels. Such modelling could be useful in anticipating potential effects of avalanches in future volcanic crises.

\section{Conclusions}

(1) Failure of the southern sector of Soufriere Hills Volcano on 26 December 1997 culminated in a devastating eruptive episode. Sector collapse produced a volcanic debris avalanche, and exposure of the depressurized face of the lava dome then resulted in generation of a powerful pyroclastic density current. A precautionary evacuation resulted in avoidance of casualties.

(2) The south-directed growth of a lava lobe and shedding of lavablock talus over the Galway's Wall and Galway's Soufriere area, particularly since early November 1997 , provided static loading on hydrothermally weakened materials that brought the flank to a condition of marginal stability.

(3) Collapse was triggered by a pulse of co-seismic, exogenous, lava shear-lobe emplacement, with subsequent gravity-driven slip-surface localization influenced by strain-weakening.

(4) The source region tended to fragment along weak layers and boundaries to form avalanche megablocks, which were then transported and further disrupted by shear along the megablock boundaries and weak internal zones. Thus the strength of the avalanche was effectively governed by the locally weakest lithologies and weak zones. Shear was focused towards the base of thc avalanche, accounting for the basal shear fabric, and for the transport of less-deformed megablock facies within the body of the flow.

(51 The resulting debris avalanche was sustained and consisted of several flow pulses that reflected complexities of the source disruption, varying flow properties of the older rocks and dome talus, and channel topography. Al major bends, the avalanche separated into channelled and overspill flows, and in the distal region, stacked sets of the main lithologies occur with a hummocky surface and with abrupt flow-unit snouts.

(6) Numerical simulations support field observations that the avalanche dynamics were governed by basal friction, and suggest that this friction was dependent upon the materials, and also the thickness and the velocity of the flowing mass. The low values of friction implied by the simulations are consistent with geotechnical test data and the inferred localized presence of pore-water pressures.

We are primarily grateful to our colleagues of Montserrat Volcano Observatory (MVO) for considerable, continued intellectual and field work support. We thank the UK Department for International Development for generous financial support of the volcano monitoring on Montserrat. Likewise the assistance of British Geological Survey (BGS) is acknowledged and appreciated. B.V., R.S.J.S. and S.R.Y. acknowledge support from BGS as Senior Scientist affiliated with MVO, and B.V. notes in addition, important assistance from several grants from the US National Science Foundation. Work by AB. and M.B was partly supported by grant RG1-172 of the US Civilian Research and Development Foundation awarded lo A.B.B. and B.V., and also by the Alexander von Humboldt Foundation. Field work by J.-C.K. was undertaken during time spent as a Senior Scientist with MVO. Supporting funds for J.-C.K. and G.B. were also obtained from the French PNRN (INSU-CNRS) research programmes, and the Observatoires Volcanologiques of the Institut de Physique du Globe de Paris (IPGP). $\mathrm{Ph}$.H. was supported by the Commissariat a 1'Energie Atomique, France. 
We recall with sadness and appreciation our colleague Peter Francis, a charter member with H. Glicken of Friends of Volcanic Debris Avalanches, with both being contributors of seminal works. We thank the helicopter pilots, particularly J. McMahon, A. Grouchy, and pilots from Bajan Helicopters (Montserrat Air Support Unit), for their skill and help, often beyond the call of duty. K. West and M. Feuillard offered photographs for our use, and many other photographs used were provided by staff of MVO. B.V. acknowledge helpful interchanges with colleagues D. Elsworth, H. R. Hardy, E. Kimball, H. W. Shen, and E. Oh. D. Hidayat, R. Herd, F. Donnadieu, and M. Volero helped with drafting. Critical reviews by R. E. A. Robertson and S. Self, and the exceptional editorship of P. Kokelaar, led to significant improvement of the paper. The assistance of J. K. McClintock in many matters is much appreciated. Published by permission of the Director, BGS (NERC).

\section{Appendix}

\section{Geotechnical tests}

For most direct shear tests on Sample I5-2A, well-mixed moist samples were pushed through a $2 \mathrm{~mm}$ sieve and moulded into the shear frame, which had a diameter of $6 \mathrm{~cm}$. A normal stress of 0.43 $\mathrm{MPa}$ was applied, the specimens were consolidated in a water-saturated state, and slow shearing accomplished at rates of, typically, $1.3 \times 10^{-4} \mathrm{mms}^{-1}$. The specimens were then reverse-sheared through a number of cycles to, usually, cumulative displacements of 90-40 $\mathrm{mm}$ or more, to provide a measure of displacement-weakening. These procedures were repeated for a normal pressure range of $0.86-1.72 \mathrm{MPa}$. Similar tests were carried out on clay-rich block sample 15-2C, but in this case the block was cored with a thin-walled tube, and core specimens were extruded, trimmed, and inserted into the direct shear frame. Similar tests were also conducted on disaggregated, weathered tuffs from the Galway's Wall and Gages Wall areas of English's Crater (Fig. 2).

For the block samples of tuff collected at Galway's Wall and Gages Wall, the blocks were cored (2.5 cm diameter) and duplicate right-cylinder specimens were subjected to laboratory triaxial testing to determine the shear strength of intact material as a function of confining pressure. Tests were conducted dry at room temperature, using loading rates of $138 \mathrm{kPa} \mathrm{s}^{-1}$, with confining pressures varied from 0.62-9.93 $\mathrm{MPa}$. Additional testing was carried out to obtain intact tensile strengths by the method of cylinder edge-loading.

\section{References}

ALIDIBIROV, M. \& DINGWELL I. D. B. 1996. Magma fragmentation by rapid decompression. Nature, 380, 146-148.

ASSIER, S, HEINRICH, P., SABATIER, P. C., SAVOYE. B. \& BOURILLET. J. F. 2000. Numerical modeling of a landslide-generated tsunami: the 1979 Nice event. Pure and Applied Geophysics. 157, 1707 -1727.

Beget, J. \& Kienle. J. 1992. Cyclic formation of debris avalanches at Mount St. Augustine volcano. Nature. 356, 701-704.

BELL. F. G. 1993. Engineering Geology. Blackwell. London.

BeLousov, A. B. 1996. Pyroclastic deposits of March 301956 directed blast at Bezymianny volcano. Bulletin of Volcanology. 57, 649-662.

BeLousov. A. B. \& BOGOYAVLENSKAYA, G. 1988. Debris avalanche of the 1956 Bezymianny eruption. Proceedings Kagoshima International Conference on Volcanoes, 460-462.

Belousov, A. B., Belolsova. M. \& Voight. B. 1999. Multiple edifice failures, debris avalanches, and associated eruptions in the Holocene history of Shiveluch volcano. Kamchatka. Russia. Bulletin of Volcanology, 61, 324-342

BouDON, G. 2001. Instabilites gravilalionnelles de l'arc volcanique des petites Antilles. Atelier sur les Aleas Volcaniques les volcans antillais - des pro cessus aux signaux. Paris. 18-19 Janvier. Institut National des Sciences de l'Univers, 4-5.

Boudon, G., SEMET. M. P. \& Vincent. P. M. 1984. Flank failure-directed blast eruption ET La Soufriere de Guadaloupe, French West Indies: a 3.000 year old Mount St Helens? Geology. 12, 350-353.

BOUDON, G.. VILLEMANT. B., KOMOROWSKI. J-C., ILDEFONSE, PH., HAMMOUYA, G. \& SEMET, M. P. 1996. The hydrothermal system of Soufriere
Hills volcano, Montserrat (West Indies): Chemical, inineralogical, and microtextural signatures in fluids, altered rocks, and 1995-96 tephra. In: WADGE:, G. (ed.) The Soufriere Hills Eruption, Montserrat. Discussion Meeting of the Volcanic Studies Group of the Geological Society. 27 November 1996. Montserrat Volcano Observatory and Geological Society of London. 31-34.

Boudon. G.. Villemant. B., KqMOROWSKI, J.-C., ILDEFonse. P. \& SEMET. M. P. I998. The hydrothermal system at Soufriere Hills volcano, Montserrat (West Indies): Characterization and role in the ongoing eruption. Geophysical Research Letters. 25, 3693-3696.

Boudon. G.. KomorowskJ. J-C.. Semet, M., Le Friant. A. \& Deplus. C. 1999. Frequent volcanic flank -collapses in the Lesser Antilles arc: origin and hazards. EOS, Transactions, American Geophysical Union, 80(46). F1142.

BRomHeAd, E. N. 1986. The Stability of Slopes. Surrey University. London.

CALDER, E. S., Young, S. R.. SPARKS, R. S. J.er al. 1998. The Boxing Day collapse, 26 December 1997. Montserrat Volcano Observatory Special Report 6.

CAstellana, B , Davidson, J. P., BelOUSOV, A. B. \& Belousova. M. 1995 Milestones of geology of the Avachinskiy volcano, Kamchatka, Russia. Eos, Transactions. American Geophysical Union, 76, 537.

Chiodini, G., Cioni. R., Frullani, A., Guidi, M., Marini. L., Prati, F. \& RACO. B. 1996. Fluid geochemistry of Montserrat Island, West Indies. Bulletin of Volcanology, 58, 380-392.

COETZEE. M. J., HART. R D., VARONA, P. D. \& CUNDALL. P. A. 1998. FLAC Basics. Itasca.

Crandell, D. R., Miller. C. D., Glicken. H. X., Christiansen. R. L. \& NEWHALL, C. G. 1984. Catastrophic debris avalanche from ancestral Mount Shasta volcano, California. Geology. 12, 143 -146.

CUNDALL, P. \& BOARD. M. I988. A microcomputer program for modeling large-strain plasticity problems. In: Numerical Methods in Geomechanics (Proceedings 6th International Conference, Insbruck. Austria. April 1988). Balkema, Rotterdam. 2101 -2108.

DADE, W. B. \& HUPPERT, H. E. 1998. Long-runout rockfalls. Geology. 26. 803-806.

DECKER, R. W. 1981. The 1980 activity: a case study in volcanic eruption forecasting. In: LIPMAN. P. W. \& MullineAuX, D. R. (eds) The 1980 Eruptions of Mount St Helens, Washington. US Geological Survey. Professional Paper. 1250, 815-820.

Deplus. C. Boudon, G., ChemineE. J-T.. ET AL. 1999. Large-scale debris avalanche deposits on the western flank of the Lesser Antilles arc revealed by the Aguadomar Cruise. Eos, Transactions, American Geophysical Union, 80(46). 1152.

DETOURNAY, C., HART, R. (eds) 1999. FLAC and Numerical Modeling in Geomechanics. Balkema. Rotterdam.

DONNADIEU. F. \& MERLE, O. 1998. Experiments on the indentation process during cryptodome intrusions: new insights into Mount St Helens deformation. Geology, 26, 79-82.

DRUITT. T. H. 1998. Pyroclastic density currents. In: GILBERT, .J S. \& SPARKS, R. S. J. (eds) The Physics of Explosive Volcanic Eruptions. Geological Society. London, Special Publications. 145, 145-182.

DRUITT T.H., CALDER. E. S., COLE. P. D. ET AL. 2002. Small-volume, highly mobile pyroclastic flows formed by rapid sedimentation from pyroclastic surges at Soufriere Hills Volcano. Montserrat: an important volcanic hazard. In: D R U II T. T. H. \& KoKelaAR. B. P. (eds) The Eruption of Soujriere Hills Volcano, Montserrat. from 1995 to 1999. Geological Society, London, Memoirs. 21, 263-279.

DunCAN. J. M. 1992. State-of-the art: static stability and deformation analysis. American Society of Civil Engineers. Ceootechnical Engineering Division Special Publication, 31, 222-265.

DUNCAN. J. M. 1996. State-of-the-art: limit equilibrium and finite-element analysis of slopes. American Society of Civil Engineers, Journal of Geotechnical Engineering. 121, 577-596.

FINK. J. H. \& KIEFFER. S. W. 1993. Estimates of pyroclastic flow velocities resulting from explosive disintegration of lava domes. Nature. 363, 612-614.

FISHER, R. V., GLICKEN. H. X. \& HOBLITT, R. P. 1987. May 18 1980, Mount St Helens deposits in South Coldwater Creek. Washington. Journal of Geophysical Research, 92(B 10). 10 267-10 283.

FRANCIS, P. W. \& SELF, S. 1987. Collapsing volcanoes. Scientific American, 287, 90-99.

Francis, P. W. \& WeLLS. G. L. 1987. Landsat thematic mapper observations of debris avalanche deposits in the Cenlral Andes. Bulletin of Volcanology. 50, 258-278. 
Francis. P. W., GardeWec. M., Ramirez. C. F. \& Rothery, D. A. 1985. Catastrophic debris avalanche deposit of Socompa volcano, northern Chile. Geology, 13, 600-603.

FREDLUNG. D. G. 1984. Analytical methods for slope stability analysis. Proceedings 4th International Symposium on Landslides. Toronto. Vol. 1, 229-250.

GIGGENBACH. W. F. 1992. Magma degassing and mineral deposition in hydrothermal systems along convergent plate boundaries. Economic Geology, 87,1927-1944.

GLICKEN, H. 1986. Rockslide-debris avalanche of May 18 1980. Mount St Helens Volcano. Washington. PhD dissertation. University of California at Santa Barbara.

GLICKEN. H. 1991. Sedimentary architecture of large-volume debris avalanches. In: FiSHER. R.V. \& SMITH. G. A. (eds) Sedimentation in Volcanic Settings. Society of Sedimentary Geologists (SEPM), Special Publications, 45, 99 -106.

GLICKEN. H. 1998. Rockslide-debris avalanche of May 18 1980. Mount St. Helens volcano. Washington. Bulletin Geological Society of Japan. 49 (2/3), 55-106.

GorshKOv, G. S. 1959. Gigantic eruption of the volcano Bezymianny. Bulletin of Volcanology, 21. 77-109.

GoRshKov, G. S. 1962. On the classification and terminology of Pelee and Katmai type eruptions. Bulletin of Volcanology, 24, 155-165.

Heinrich P., Mangeney, A., Guibourg, S., Roche, R., Boudon. G. \& CHEMINEE. J-L. 1998. Simulation of water waves generated by a potential debris avalanche in Montserrat,. Leaser Antilles. Geophysical Research Letters, 25(19), 3697-3700.

Heinrich. P., Piatanesi. A., OKal. E. \& Hebert. H. 2000. Near-field modelling of the July 171998 tsunami in Papua New Guinea. Geophysical Research Letters, 27(19), 3037-3040.

HeinRich, P., PiAtANESi A. \& HEBERT. H. 2001. Numerical modelling of tsunami generation and propagation from submarine slumps: the 1998 Papua New Guinea event. Geophysics Journal International, 145(1), $97-111$

Heinrich, P., Boudon. G., Komorowski, J-C., Sparks, K. S. J., Herd, R. \& VOIGHT. B. 2001. Numerical simulation of the December 1997 debris avalanche in Monlserrat, Lesser Antilles. Geophysical Research Letters, 28, 2529-2532.

HoBlitT, R. P. 2000. Was the 18 May 1980 lateral blast al Mt St Helens the product of two explosions? Philosophical Transactions of the Royal Society, London, A358, 1639-1661.

HoEK, E. 1983. Strength of jointed rock masses. Geotechnique, 33, 187-223.

HOEK. E. \& BROWN. E. T. 1980. Empirical strength criterion for rock masses. American Society of Civil Engineers. Journal of Geotechnical Engineering. 106. 1013-1035.

HOEK, E., KAISER, P. K. \& BAWDEN. W. F. 1994. Support of Underground Excavations in Hard Hock. Balkema, Rotterdam.

HUTTER, K.. 1996. Avalanche dynamics, a review. In: SINGH. V. P. (ed.) Hydrology of Disasters. Kluwer. Dordrecht. 317-394.

INMAN. D. L. 1952. Measures for describing the size distribution of sediments. Journal of Sedimentary Petrology. 22.125-145.

Komorowski, J-C, Glicken, H. X \& Sheridan, M. 1991. Secondary electron imagery of microcracks and hackly fracture surfaces in sand-size clasts from the 1980 Mount St Helens debris-avalanche deposit: implications for particle-particle interactions. Geology. 19, 261-264.

Komorowski, .I-C, Norton, G., Boudon. G. ET AL.. 1999. The 1997 flank-collapse of Soufriere Hills volcano, Montserrat: Constraints on emplacement mechanisms from debris avalanche morphological and textural data. Eos, Transactions, American Geophysical Union, 80(46), 1152.

Kramer, S. L. 1996. Geotechnical Earthquake Engineering. Prentice Hall, Upper Saddle River, New Jersey.

LaCroiX. A. 1904. La Montagne Pelee et ses eruption. Masson et Cie, Paris

LAmBe. T. W. \& WhitMan, R. V. 1969. Soil Mechanics. John Wiley. New York.

LiPMAN. P. W. \& MulLinEauX. D. R. (eds) 1981. The 1980 Eruptions of Mount St Helens, Washington. US Geological Survey, Professional Paper, 1250.

Lipman. P. W., Moore, J. G. \& Swanson, D. A. 1981. Bulging of the north flank before the May 18 eruption: geodetic data. In: LIPMAN. P. W. \& MULLINEAIUX, D. R. (eds) The 1980 Eruptions of Mount St Helens. Washington, US Geological Survey, Professional Papers. 1250 143-156.

MacGREGOR, A. G. 1952. Eruptive mechanisms: Mt. Pelee, the Soufriere, St. Vincent, and the Valley of Ten Thousand Smokes. Bulletin Volcanologique, 12, 49-74.
MANGANey. A., HeinRICH, PH. \& Roche. R. 2000. Analytical and numerical solution of dam-break problem for application to water floods, debris and snow avalanches. Pure and Applied Geophysics. 157(6-8), 1081-1096.

MAyrerRy. G. C, Rose, W. I. \& Bluth, G. 1998. Analysis of the ash cloud from the December 261997 (Boxing Day) dome collapse of Soufriere Hills Volcano, Montserrat using GOES-8 Imagery. Eos, Transactions, American Geophysical Union. 79, 1014.

MEdLEY, E. 1997. Geological engineering of bimrocks (abstract). Association of Engineering Geologists. Annual Meeting.

Miller, A. D,. STEWART, R. C. White, R. A. ET AL. 1998. Seismicity associated with dome growth and collapse at the Soufriere Hills Volcano, Montserrat. Geophysical Research Letters, 25, 3401-3404

NAAim. M., Vial, S. \& CoUtURE, R, 1997. Saint-Venant approach for rock avalanche modeling. Saint-Venant Symposium. August 28-29, Paris.

Palmer, B, A,. Alloway. B. V. \& Neall, V. L, 1991. Volcanic-debris-avalanche deposits in New Zealand - lithofacies organization in unconfined wet-avalanche flows. In: FIISHER, R. V. \& Smith, G. A. (eds) Sedimentation in Volcanic Settings. Society of Sedimentary Geologists (SEPM), Special Publications, 45, 89-98.

PARISEAU, W. G. \& VOIGHT, B. 1979, Rockslides and avalanches: basic principles and perspectives in the realm of civil and mining operations. In: VOIGHT. B. (ed.) Rocks/ides and Avalanches. 2: Engineering Sites. Elsevier. Amsterdam, 1-92.

PouliQUEN. O. 1999. Scaling laws in granular flows down rough inclined planes. Physics of fluids, 11(3). 542-548.

REA, W. J. 1974. The volcanic geology and petrology of Montserrat, West Indies. Journal of the Geological Society. London, 130, 341-366.

REICHE. P. 1937. The toreva-block - a distinctive landslide type. Journal of Geology, 45. 538-548.

Ritchie, L. J., Cole. P. D. \& Sparks, R. S. J. 2002. Sedimentology of deposits from the pyroclastic density current of 26 December 1997 at Soufriere Hills Volcano, Montserrat. In: DrUITT, T, H. \& KoKELAAR. B. P. (eds) The Eruption of Soufriere Hills Volcano. Montserrat, from 1995 to 1999. Geological Society, London. Memoirs, 21, 435-456.

Robertson. R. E. A., Cole, P., Sparks, R. S. J. ET AL. 1998. The explosive eruption of Soufriere Hills Volcano, Montserrat, West Indies, 17 September, 1996. Geophysical Research Letters, 25, 3429-3432.

Roobol, M. J. \& SMith, A. L. 1998. Pyroclastic stratigraphy of the Soufriere Hills volcano, Montserrat - Implications for the present eruption. Geophysical Research Letters, 25, 3193-3396.

SASSA. K. 1988. Geotechnical model for the motion of landslides. Proceedings 5th Internalional Symposium on Landslides, Lausanne, Vol. 1, 37-55.

SAVAGE, S. U. \& HUTIER, K. I989. The motion of a finite mass of granular material down a rough incline. Journal of Fluid Mechanics, 199, $177-215$.

SIEBERT. L. 1984. Large volcanic debris avalanches: characteristics of source areas, deposits, and associated eruptions. Journal of Volcanology and Geothermal Research, 22, 163-197.

SIEBERT. L. 1996. Hazards of large volcanic debris avalanches and associated eruptive phenomena. In: SCAR PA, R. \& TILLING. R, I. (eds) Monitoring and mitigation of volcano hazards. Springer-Verlag. Berlin, 541-572.

Siebert L., Glicken H. \& Ui T. 1987. Volcanic hazards from Bezymianny-and Bandai-type eruptions. Bulletin oj Volcanology, 49, 435-459.

Siebert L., Beget, J. E. \& GLiCKEN H. 1995. The 1883 and late-prehistoric eruptions of Augustine volcano, Alaska. Journal of Volcanology and Geothermal Research, 66, 367-395.

SLINGERLAND. R. L. \& VOIGHT, B. 1979. Occurrences, properties, and predictive models of landslide-generated water waves. In: VoIGHT, B. (ed.) Rockslides and Avalanches. 2. Engineering Sites. Elsevier. Amsterdam. 317-397.

SousA, J. \& VoIGHT. B. 1995. Multiple-pulsed debris avalanche emplacement at Mount St Helens in 1980: evidence from numerical continuum flow simulation. Journal of Volcanology and Geothermal Research. 66, 227-250.

Sparks, R. S. J., BARClay J,. CALDER E. S. ET AL. 2002. Generation of a debris avalanche and violent pyroclastic density current on 26 December (Boxing Day) 1997 at Soufriere Hills Volcano. Montserrat. In: DRUITT, T. H. \& KOKELAAR, B. P. (eds) The Eruption of Soufriere Hills Volcano, Montserrat, from 1995 To 1999. Geological Society, London, Memoirs, 21, 409-434.

Ui. T. 1983. Volcanic dry avalanche deposits identification and comparison with non-volcanic debris stream deposits. Journal of Volcanology and Geothermal Research, 18. 135-150. 
Ul, T. \& GLicken. H. 1986. Internal structural variations in a debris-avalanche deposit from ancestral Mount Shasta, California, USA. Bulletin of Volcanology, 48. 189 -194.

Ui. T., KAWACHI, S. \& NEALL, V. E. 1986. Fragmentation of debris avalanches dtiring flowage. Evidence from the Pungarehu Formation. Mount Egmont, New Zealand. Journal of Volcanology and Geothermal Research, 27, 255-264.

Ui. T., TAKarada, S. \& Yoshimoto, M. 2000. Debris avalanches. in: Sigurdsson. H. (ed.) Encyclopedia of Volcanoes. Academic Press, San Diego, 617-626.

VAN WYK DE VRIES, B. \& Francis. P. W. 1996. Catastrophic collapse at stratovolcanoes induced by gradual volcano spreading. Nature, 387, 387-390.

Van WVK De Vries. B., Self, S., Francis. P. \& Keszthelyi. L. 1999. Development of the Socompa debris avalanche (N Chile) from a spreading volcanic edifice. Eos, Transactions, American Geophysical Union. 80(46). 1142.

VoIGHT. B. 1978. Lower Gros Ventre slide, Wyoming, USA. In: VoIght, B. (ed.) Rockslides and Avalanches. I: Natural Phenomena. Elsevier, Amsterdam, 113-166.

VOIGHT, B. 1980. Slope stability hazards. Mount St Helens volcano. Washington. File report. US Geological Survey Cascades Volcano Observatory. Washington (reproduced as appendix in: VoIGHT. B. 2000. Stability of andesitc volcanoes and lava domes. Philosophical Transactions of the Royal Society, London. A 358. 1694-1701).

VoIgHT, B. 1996. Strength of wall rock of English's Crater, Soufriere Hills volcano, Montserrat. In: WADGE, G. (ed.) The Soufriere Hills Eruption, Montserrat. Discussion Meeting of the Volcanic Studies Group of the Geological Society, 27 November 1996. Montserrat Volcano Observatory and Geological Society. London, 29-30.

Voight, B. 2000. Stability of andesile volcanoes and lava domes. Philosophical Transactions of the Royal Society, London. A 358. 1663-1703.

VOIGHT, B. \& ELSWORTH. D. 1997. Failure of volcano slopes. Geotechnique, 47, 1-31.

Voight. B. \& Elsworth, D. 2000. Stability and collapse of hazardous gas-pressurized lava domes. Geophysical Research Letters, 48. 1-4.

Voight, B., GLicken. H,, Janda R.J. \& Douglass, P. M. 1981, Catastrophic rockslide avalanche of May 18. In: LIPMAN. P. W. \& MULLINEAUX. D. R. (eds) The 1980 Eruptions of Mount St Helens. Washington. US Geological .Survey, Professional Papers. 1250, 347-378.
Voight, B., Janda. R, J., GLiCKFN, H. \& Douglass, P. M. 1983. Nature and mechanics of the Mount St Helens rock slide-avalanche of 18 May 1980. Geotechnique. 33, 243-273,

VoIGHT, B., JANDA. R. J., GLICKEN, H. \& DougLASS, P. M. 1985. Nature and mechanics of the Mount St Helens rockslide-avalanche of 18 May 1980: Reply to discussion. Ceotechnique, 35, 357-368.

Voight, B., Hobi.ITT. R. P., Clarke, A. B., LOCKhart, A. B.. Miller. A. D., LYNCH, L. \& MCMAHON, J. 1998. Remarkable cyclic ground deformation monitored in real time on Montserrat and its use in eruption forecasting. Geophysical Research Letters. 25, 3405- 3408.

Voight, B., Sparks, R. S. J., Miller, A. D. ET AL. 1999. Magma flow instability and cyclic activity al Soufriere Hills Volcano, Montserrat, B.W.I. Science. 283. 1138-1142.

WADGE, G. \& IsAACS, M. C. 1988. Mapping the volcanic hazards from Soufriere Hills volcano. Montserrat, West Indies using an image processor. Journal of the Geological Society. London, 145, 541-551.

WADCF, G., FRANCIS, P. W. \& RAMIREZ. C. F, 1995, The Socompa collapse and avalanche event. Journal of Volcanology and Geothermal Research, 66, 309-336.

Wadge G., Woods A., Jackson, P., Bower, S., Williams, C. \& HulsemanN. F. 1998. A hazard evaluation system for Montserrat. In: Forecasts and Warnings. UK Coordination Committee for IDNDR. Thomas Telford, 3.1-3.32.

WALKER. G. P. L. 1971. Grain-size characteristics of pyroclastic deposits. Journal of Geology, 79, 696-714.

Woods. A. W., Sparks, R. S. J., Ritchie. L, J., Batey. J., Gladstone, C. \& BIJRSIK, M. 1. 2002, The explosive decompression of a pressurized volcanic dome: the 26 December 1997 collapse and explosion of Soufriere Hills Volcano, Montserrat. in: DruitT. T. H. \& KoKelaAR, B. P. (eds) The Eruption of Soufriere Hills Volcano, Montserrat, from 1995 to 1999. Geological Society, London, Memoirs. 21, 457-466.

YOUNG, S. R., SPARKS R. S. J., ASPINALL, W, P.. LYNCH L. L, MILLER. A. D., Robertson R. E. A. \& Sherherd, J. B. 1998. Overview of the eruption of Soufriere Hills Volcano. Montserrat. July 181995 to December 1997. Geophysical Research Letters, 25. 3389-3393.

Young. S, R., VOIGHT, B.. BARCLAY, J et AL. 2002. Hazard implications of small-scale edifice instability and sector collapse: a case history from Soufriere Hills Volcano. Montserrat. In: DRUTTT, T. H. \& KoKELLAAR. B. P. (eds) The Eruption of Soufriere Hills Volcano, Montserrat, from 1995 to 1999. Geological Society. London. Memoirs, 21, 349-361. 